\title{
Technical Status Report: Preliminary Glass Formulation Report for INEEL HAW
}

by

D. Peeler

RECEIVER

Westinghouse Savannah River Company

JUN 111998

Savannah River Site

Aiken, South Carolina 29808

1. Reamer

O. STI

J. Vienna

J. A. Crum

This paper was prepared in connection with work done under the above contract number with the U.S.

Department of Energy. By acceptance of this paper, the publisher and/or recipient acknowledges the U.S. Government's right to retain a nonexclusive, royalty-free license in and to any copyright covering this paper, along with the right to reproduce and to authorize others to reproduce all or part of the copyrighted paper.

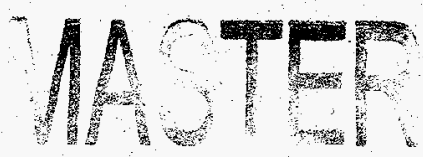

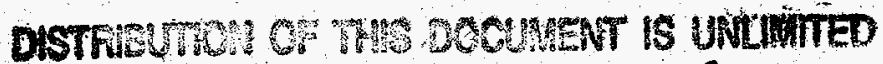


WSRC-TR-98-00132

Rev. 1

\section{Technical Status Report \\ Preliminary Glass Formulation Report for INEEL HAW}

Tanks Focus Area

Technical Task Plan: SR1-6-WT-31

Process for Idaho HAW Immobilization

Westinghouse Savannah River Company

D.K. Peeler

I.A. Reamer

Battelle, Pacific Northwest National Laboratory

J.D. Vienna

J.V. Crum

March 30, 1998

Prepared for the U.S. Department of Energy

Westinghouse Savannah River Company

Savannah River Technology Center

Aiken, SC 29808 


\section{DISCLAIMER}

This report was prepared as an account of work sponsored by an agency of the United States Government. Neither the United States Government nor any agency thereof, nor any of their employees, makes any warranty, express or implied, or assumes any legal liability or responsibility for the accuracy, completeness, or usefulness of any information, apparatus, product, or process disclosed, or represents that its use would not infringe privately owned rights. Reference herein to any specific commercial product, process, or service by trade name, trademark, manufacturer, or otherwise does not necessarily constitute or imply its endorsement, recommendation, or favoring by the United States Government or any agency thereof. The views and opinions of authors expressed herein do not necessarily state or reflect those of the United States Government or any agency thereof.

This report has been reproduced directly from the best available copy.

Available to DOE and DOE contractors from the Office of Scientific and Technical Information, P.O. Box 62, Oak Ridge, TN 37831; prices available from (615) 576-8401.

Available to the public from the National Technical Information Service, U.S. Department of Commerce, 5285 Port Royal Road, Springfield, VA 22161. 


\section{DISCLAIMER}

Portions of this document may be illegible electronic image products. Images are produced from the best available original document. 


\section{Executive Summary}

Preliminary gláss formulation work has been initiated at Pacific Northwest National Laboratory (PNNL) and the Savannah River Technology Center (SRTC) to support immobilization efforts of Idaho National Engineering and Environmental Laboratory (INEEL) high activity waste (HAW). Based on current pretreatment flow sheet assumptions, several glasses were fabricated and tested using an average "All Blend" waste stream composition which is dominated by the presence of $\mathrm{ZrO}_{2}$ (i.e., approximately 80 $w t \%)$. The results of this initial work show that immobilization via vitrification is a viable option for a specific INEEL HAW waste stream. Waste loadings of at least $19 \mathrm{wt} \%$ can be achieved for the "All Blend" stream while maintaining targeted processing and product performance criteria. This waste loading translates into a $\mathrm{ZrO}_{2}$ content in excess of 15 wt\% in the final glass waste form. Frits developed for this work are based in the alkali borosilicate system. Although the results indicate that vitrification can be used to immobilize the "All Blend" waste stream, the glass compositions are by no means optimized.

SRTC and PNNL recommend the following frit composition be used in the initial INEEL $1 / 4$ scaled melter run utilizing a simulated "All Blend" waste stream:

\begin{tabular}{|c|c|c|}
\hline Frit Identification: & BL-9 & \\
\hline & Oxide & $w t \%$ \\
\hline & $\mathrm{SiO}_{2}$ & 62.63 \\
\hline & $\mathrm{B}_{2} \mathrm{O}_{3}$ & 18.52 \\
\hline & $\mathrm{Li}_{2} \mathrm{O}$ & 7.41 \\
\hline & $\mathrm{Na}_{2} \mathrm{O}$ & 11.44 \\
\hline Waste Loading: & $19.0 \mathrm{wt} \%$ & \\
\hline Waste Stream: & "All Blend" & \\
\hline Nominal Processing Temperature: & $1150^{\circ} \mathrm{C}$ & \\
\hline
\end{tabular}

The target glass composition meets all targeted primary processing and product performance criteria. Liquidus temperature of $\mathrm{BL}-9$ (glass) is below $1050^{\circ} \mathrm{C}$ with $\mathrm{Na}_{2} \mathrm{ZrSi}_{2} \mathrm{O}_{7}$ identified as the primary crystalline phase. Viscosity at $1150^{\circ} \mathrm{C}$ is approximately 60 Poise (6.0 Paes). Durability results (as defined by ASTM-C-1285-94) indicate that the normalized $\mathrm{B}, \mathrm{Na}$, and $\mathrm{Li}$ releases are approximately one order of magnitude less than those of the EA glass.

SRTC and PNNL also recommend that INEEL fabricate and test BL-9 (on a laboratory-scale) to confirm that the glass meets the specifications prior to melter processing. The results of the materials of construction (refractory and electrode) corrosion tests should also be considered prior to melter processing. This study has not addressed scale-up issues (i.e., crucible scale to melter scale). One concern that was only partially addressed was the devitrification potential within the drain tube during melter idling. Although the limited results suggest that devitrification may occur within the drain tube, based on the type and extent of devitrification for a single time/temperature data point, the crystals readily redissolved at $1050^{\circ} \mathrm{C}$ within 4 hours. 


\section{GLASS COMPOSITION / PROPERTY RELATIONSHIPS}

The following tables summarize the major observations (homogeneity, viscosity, liquidus temperature, and durability) and targeted glass compositions for all glasses tested in the initial scoping studies. These tables can be used as a reference guide to track sequential glass formulations developed during the study.

Major Observations for Initial “All Blend" Glasses

\begin{tabular}{|c|c|c|c|c|c|c|}
\hline Glass ID & $\begin{array}{l}\text { Waste Loading } \\
\text { (wt\%) }\end{array}$ & $\begin{array}{c}\mathrm{ZrO}_{2} \text { Content } \\
\text { in Glass }\end{array}$ & $\begin{array}{l}\text { Homogeneity } \\
\text { (as fabricated) }\end{array}$ & $\begin{array}{c}\text { Viscosity at } \\
1150^{\circ} \mathrm{C}\end{array}$ & Liquidus $\left({ }^{\circ} \mathrm{C}\right)$ & $\begin{array}{c}\mathrm{PCT} \\
(\mathrm{B}, \mathrm{Na} \text {, and } \mathrm{Li})\end{array}$ \\
\hline BL-1 & 17.7 & 14.0 & $\begin{array}{l}\text { Yes, visual and } \\
\text { optical }\end{array}$ & $9.5 \mathrm{~Pa}-\mathrm{sec}$ & $>1100$ & Not measured \\
\hline BL-1R (remelt) & 17.7 & 13.7 & Yes, visual & Not measured & $>1100$ & Not measured \\
\hline BL-1Li & 17.7 & 13.7 & Yes, visual & Not measured & $>1100$ & Not measured \\
\hline $\mathrm{BL}-1 \mathrm{Na}$ & $\overline{17.7}$ & 13.7 & Yes, visual & Not measured & $>1100$ & Not measured \\
\hline BL-1K & 17.7 & 13.7 & Yes, visual & Not measured & $>1100$ & Not measured \\
\hline BL-2 & 19.0 & 15.0 & $\begin{array}{l}\text { Yes, visual and } \\
\text { optical }\end{array}$ & Not measured & $\begin{array}{c}1077^{\circ} \mathrm{C} \\
\mathrm{Na}_{2} \mathrm{ZrSi}_{2} \mathrm{O}_{7}\end{array}$ & Not measured \\
\hline BL-3. & 19.0 & 15.0 & No, visual & Not measured & Not measured & Not measured \\
\hline$\overline{B L}-4$ & 18.3 & 14.5 & $\begin{array}{c}\text { Yes, visual, } \\
\text { optical, and XRD }\end{array}$ & Not measured & $<1050$ & Inadequate \\
\hline BL-5 & 19.0 & 15.0 & $\begin{array}{c}\text { Yes, visual, } \\
\text { optical, and XRD }\end{array}$ & Not measured & $<1050$ & Inadequate \\
\hline BL-6 & 19.0 & 15.0 & $\begin{array}{l}\text { Yes, visual and } \\
\text { optical }\end{array}$ & Not measured & $<1050$ & Not measured \\
\hline BL-7 & 19.0 & 15.0 & $\begin{array}{l}\text { Yes, visual and } \\
\text { optical }\end{array}$ & Not measured & $<1000$ & Not measured \\
\hline BL-8 & 19.0 & 15.0 & $\begin{array}{c}\text { Yes, visual, } \\
\text { optical, and XRD }\end{array}$ & $8.3 \mathrm{~Pa}-\mathrm{sec}$ & $\begin{array}{c}<1025 \\
\mathrm{Na}_{2} \mathrm{ZrSi}_{2} \mathrm{O}_{7}\end{array}$ & Acceptable \\
\hline BL-9 & 19.0 & 15.0 & $\begin{array}{c}\text { Yes, visual, } \\
\text { optical, and XRD }\end{array}$ & $5.9 \mathrm{~Pa}-\mathrm{sec}$ & $\begin{array}{c}<1050,>1025 \\
\mathrm{Na}_{2} \mathrm{ZrSi}_{2} \mathrm{O}_{7}\end{array}$ & Acceptable \\
\hline
\end{tabular}

Notes:

- Waste loading given as weight \% of the INEEL "All Blend" stream on a dry oxide basis.

- Melt temperature normally $1150^{\circ} \mathrm{C}$ with a $4-5$ hour residence time.

- Homogeneity defined by the presence of a single phase (i.e., glass). Undissolved solids were deemed acceptable.

Homogeneity evaluated via visual observations, optical microscopy, and X-ray diffraction.

- Viscosity was measured on select glasses using a rotating spindle technique. For those glasses which viscosity - was not formally measured, viscosity was noted based on visual observations of the pour.

- ' Liquidus temperature measured using a "uniform temperature" technique were samples isothermally held for 24 hours at $1050^{\circ} \mathrm{C}$ (unless otherwise noted).

- Product performance was evaluated by comparing the $\mathrm{B}, \mathrm{Na}$, and $\mathrm{Li}$ normalized releases to the EA glass via the Product Consistency Test (PCT). 
Frit and Targeted Glass Compositions for the Initial "All Blend" Glasses.

\begin{tabular}{|c|c|c|c|c|c|c|c|c|c|c|}
\hline Oxide & $\mathrm{BL}-1$ & $\mathrm{BL}-1 \mathrm{Li}$ & $\mathrm{BL}-2$ & $\mathrm{BL}-3$ & $\mathrm{BL}-4$ & $\mathrm{BL}-5$ & $\mathrm{BL}-6$ & $\mathrm{BL}-7$ & $\mathrm{BL}-8$ & $\mathrm{BL}-9$ \\
\hline $\begin{array}{c}\text { Frit } \\
\text { Composition }\end{array}$ & & & & & & & & & & \\
\hline $\mathrm{Al}_{2} \mathrm{O}_{3}$ & 3.0 & 2.9 & 0.0 & 0.0 & 0.0 & 0.0 & 0.0 & 0.0 & 2.9 & 0.0 \\
\hline $\mathrm{B}_{2} \mathrm{O}_{3}$ & 6.1 & 5.9 & 6.2 & 6.2 & 6.1 & 6.2 & 6.2 & 12.3 & 6.2 & 18.5 \\
\hline $\mathrm{Li}_{2} \mathrm{O}$ & 6.1 & 8.4 & 8.6 & 5.7 & 8.6 & 9.9 & 9.9 & 8.6 & 9.9 & 7.4 \\
\hline $\mathrm{Na}_{2} \mathrm{O}$ & 22.8 & 22.2 & 20.8 & 27.2 & 20.8 & 19.8 & 15.5 & 13.5 & 15.7 & 11.4 \\
\hline $\mathrm{SiO}_{2}$ & 62.0 & 60.5 & 64.4 & 61.0 & 64.5 & 64.2 & 68.5 & 65.6 & 65.4 & 62.6 \\
\hline & & & & & & & & & & \\
\hline $\mathrm{Glass}_{\text {Composition }}$ & & & & & & & & & & \\
\hline $\mathrm{Al}_{2} \mathrm{O}_{3}$ & 4.04 & 3.96 & 1.69 & 1.69 & 1.63 & 1.69 & 1.69 & 1.69 & 4.00 & 1.69 \\
\hline $\mathrm{B}_{2} \mathrm{O}_{3}$ & 5.00 & 4.90 & 5.00 & 5.00 & 5.00 & 4.99 & 5.00 & 10.00 & 5.00 & 15.00 \\
\hline $\mathrm{CaO}$ & 0.08 & 0.08 & 0.09 & 0.09 & 0.09 & 0.09 & 0.09 & 0.09 & 0.09 & 0.09 \\
\hline $\mathrm{Cs}_{2} \mathrm{O}$ & 0.15 & 0.15 & 0.09 & 0.09 & 0.09 & 0.09 & 0.09 & 0.09 & 0.09 & 0.09 \\
\hline $\mathrm{CuO}_{\mathrm{Fe}_{2} \mathrm{O}_{3}}$ & 0.06 & 0.06 & 0.07 & 0.07 & 0.07 & 0.07 & 0.07 & 0.07 & 0.07 & 0.07 \\
\hline $\mathrm{Gd}_{2} \mathrm{O}_{3}$ & 0.06 & 0.05 & 0.05 & 0.05 & 0.05 & 0.05 & 0.05 & 0.05 & 0.05 & 0.05 \\
\hline $\mathrm{K}_{2} \mathrm{O}$ & 1.11 & 1.09 & 1.20 & 1.20 & 1.15 & 1.20 & 1.20 & 1.20 & 1.20 & 1.20 \\
\hline $\mathrm{Li}_{2} \mathrm{O}$ & 5.03 & 6.93 & 7.00 & 4.63 & 7.00 & 8.00 & 8.00 & 7.00 & 8.00 & 6.00 \\
\hline $\mathrm{MoO}_{3}$ & 0.01 & 0.01 & 0.01 & 0.01 & 0.01 & 0.01 & 0.01 & 0.01 & 0.01 & 0.01 \\
\hline $\mathrm{Na}_{2} \mathrm{O}$ & 18.77 & 18.39 & 16.87 & 22.00 & 17.00 & 16.00 & 12.53 & 10.90 & 12.75 & 9.27 \\
\hline $\mathrm{P}_{2} \mathrm{O}_{5}$ & 0.52 & 0.51 & 0.56 & 0.56 & 0.54 & 0.56 & 0.56 & 0.56 & 0.56 & 0.56 \\
\hline $\mathrm{SiO}_{2}$ & 51.01 & 50.08 & 52.20 & 49.45 & 52.74 & 52.08 & 55.54 & 53.17 & 53.02 & 50.80 \\
\hline $\mathrm{SrO}^{\mathrm{TrO}_{2}}$ & 0.01 & 0.01 & 0.01 & 0.01 & 0.01 & 0.02 & 0.01 & 0.01 & 0.01 & 0.01 \\
\hline $\mathrm{ZrO}_{2}$ & 0.01 & 0.01 & 0.06 & 0.06 & 0.06 & 0.06 & 0.06 & 0.06 & 0.06 & 0.06 \\
\hline & 14.00 & 13.72 & 15.03 & 15.03 & 14.47 & 15.03 & 15.03 & 15.03 & 15.03 & 15.03 \\
\hline $\mathrm{Lading}_{2}$ & 17.7 & 17.3 & 19.0 & 19.0 & 18.3 & 19.0 & 19.0 & 19.0 & 19.0 & 19.0 \\
\hline & & & & & & & & & & \\
\hline
\end{tabular}




\section{ACKNOWLEDGMENTS}

The authors appreciate the guidance and funding for this task provided by the Department of Energy's (DOE) Office of Science and Technology (OST) and the Tanks Focus Area (TFA). This study is the result of a multi-institutional research program between Savannah River Technology Center (SRTC), Pacific Northwest National Laboratory (PNNL), and Idaho National Engineering and Environmental Laboratory (INEEL). The authors wish to acknowledge the following people for their significant contributions to this research.

Bill Holtzscheiter (Technical Integration Manager for the Tanks Focus Area Immobilization Task) Arlin Olson (INEEL, end user, technical guidance and review)

Carol Jantzen (SRTC, technical guidance and review)

Pavel Hrma (PNNL, technical guidance and review)

Bruce Staples (INEEL, technical guidance and review)

We also wish to knowledge the efforts of Greg Piepel (PNNL), S.K. Sundaram (PNNL), Kevin Brown (SRTC), Bond Calloway (SRTC), Tommy Edwards (SRTC), Chris Musick (INEEL), Krishna Vinjamuri (INEEL), and Brad Scholes (INEEL). 


\section{TABLE OF CONTENTS}

Executive Summary

List of Figures

List of Tables

1.0 Introduction

2.0 Preliminary INEEL Waste Stream Compositions

3.0 Primary Processing and Product Performance Criteria

3.1 Viscosity

3.2 Liquidus Temperature

3.3 Durability

4.0 Experimental

4.1 Batching and Melting

4.2 Homogeneity

4.3 Viscosity

4.4 Liquidus Temperature Constraint

4.5 Durability

5.0 Glass Form Development Studies

5.1 Initial Scoping Studies

5.1.1 BL-1 Frit

5.1.2 BL-2 Frit

5.1.3 BL-3 Frit

5.1.4 Summary of Initial Scoping Studies

5.2 BL-4 and BL-5

5.2.1 Results of Primary Processing and Product Performance Constraints

5.2.1.1 Homogeneity

5.2.1.2 Viscosity

5.2.1.3 Liquidus Temperature Constraint

5.2.1.4 Durability

5.2.1.5 Summary

5.3 BL-6 Frit

5.3.1 Homogeneity

5.3.2 Viscosity

5.3.3 Liquidus Temperature Constraint 


\section{TABLE OF CONTENTS (continued)}

5.4 BL-7 Frit

5.4.1 Homogeneity

5.4.2 Viscosity

5.4.3 Liquidus Temperature Constraint

5.5 Primary Candidates for Initial INEEL Melter Runs (BL-8 and BL-9)

5.5.1 BL-8-Frit

5.5.1.1 Homogeneity

5.5.1.2 Viscosity

5.5.1.3 Liquidus Temperature Constraint

5.5.1.4 Durability

5.5.1.5 Summary

5.5.2 BL-9 Frit

5.5.2.1 Homogeneity

5.5.2.2 Viscosity

5.5.2.3 Liquidus Temperature Constraint

5.5.2.4 Durability

5.5.2.5 Summary

5.6 Additional Testing

5.6.1 Devitrification Potential

5.6.1.1 BL-4 and BL-5

5.6.1.2 BL-8 and BL-9

5.6.2 "Redissolution" Tests

5.6.2.1 BL-4 and BL-5

5.6.2.2 BL-8 and BL-9

6.0 Melter Recommendation

7.0 References 


\section{LIST OF FIGURES}

Figure 1. XRD Results of the "As Fabricated" BL-4 Glass.

Figure 2. XRD Results of the "As Fabricated" BL-5 Glass.

Figure 3. XRD Results of BL-4 Heat Treated at $1050^{\circ} \mathrm{C}$ for 24 Hours.

Figure 4. XRD Results of BL-5 Heat Treated at $1050^{\circ} \mathrm{C}$ for 24 Hours.

Figure 5. Normalized Sodium Release by $\mathrm{PCT}$ as a Function of $\mathrm{Al}_{2} \mathrm{O}_{3}$ Addition (or Subtraction).

Figure 6. XRD Results of the "As Fabricated" BL-8 Glass.

Figure 7. High Temperature Viscosity Curve for BL-8.

Figure 8. XRD Results of BL-8 Heat Treated at $1050^{\circ} \mathrm{C}$ for 24 Hours.

Figure 9. SEM Micrograph of BL-8 Heat Treated at $1050^{\circ} \mathrm{C}$ for 24 Hours.

Figure 10. XRD Results of the "As Fabricated" BL-9 Glass.

Figure 11. High Temperature Viscosity Curve for BL-9.

Figure 12. XRD Results of BL-9 Heat Treated at $1050^{\circ} \mathrm{C}$ for 24 Hours.

Figure 13. SEM Micrograph of BL-9 Heat Treated at $1050^{\circ} \mathrm{C}$ for 24 Hours.

Figure 14. Optical Micrographs of (a) BL-4 (HT 850) and (b) BL-5 (HT 850).

Figure 15. XRD Results of BL-4 (HT 850).

Figure 16. XRD Results of BL-5 (HT 850).

Figure 17. SEM Micrograph of BL-4 (HT 850) - Cross Sectional Image.

Figure 18. EDS Spectra of a Crystal Within the Dense Surface Layer (BL-4 (HT 850)).

Figure 19. EDS Spectra of "Bulk Crystallization" (BL-4 (HT 850)).

Figure 20. SEM Micrograph of "Bulk Crystallization" (BL-4 (HT 850)).

Figure 21. SEM Micrograph of BL-5 (HT 850) - Cross Sectional Image.

Figure 22. EDS Spectra of a Crystal Within the Dense Surface Layer (BL-5 (HT850)).

Figure 23. SEM Micrograph of "Bulk Crystallization" (BL-5 (HT 850)).

Figure 24. EDS Spectra of "Bulk Crystallization" (BL-5 (HT 850)).

Figure 25. Optical Micrographs of BL-8 (HT 850) and BL-9 (HT 850).

Figure 26. XRD Results of BL-8 (HT 850).

Figure 27. XRD Results of BL-9 (HT 850).

Figure 28. XRD Results of BL-8 (HT 850) from Partnering Laboratory.

Figure 29. XRD Results of BL-8 (HT 850) from Partnering Laboratory.

Figure 30. SEM Micrograph of BL-8 (HT 850).

Figure 31. SEM Micrograph of "Surface Crystallization" (BL-8 (HT 850)).

Figure 32. EDS Spectra of "Surface Crystallization" (BL-8 (HT 850)).

Figure 33. SEM Micrograph of BL-8 (HT 850) - Cross Sectional Image.

Figure 34. SEM Micrograph of "Surface Crystallization" (BL-9 (HT 850)).

Figure 35. SEM Micrograph of BL-9 (HT 850) - Cross Sectional Image. 
Figure 36. SEM Micrograph of "Surface Crystallization" (BL-9 (HT 850)) (100x).

Figure 37. SEM Micrograph of "Surface Crystallization" (BL-9 (HT 850)) (2000x).

Figure 38. EDS Spectra of "Surface Crystallization" (BL-9 (HT 850)).

Figure 39. XRD Results of the "Redissolution Test" with BL-4 (HT 850).

Figure 40. XRD Results of the "Redissolution Test" with BL-5 (HT 850).

Figure 41. SEM Micrograph of BL-8 After "Redissolution" Test at $1050^{\circ} \mathrm{C}$ for 4 Hours.

Figure 42. SEM Micrograph of BL-9 After "Redissolution" Test at $1050^{\circ} \mathrm{C}$ for 4 Hours.

Figure 43. XRD Results of BL-8 After "Redissolution" Test at $1050^{\circ} \mathrm{C}$ for 4 Hours.

Figure 44. XRD Results of BL-9 After "Redissolution" Test at $1050^{\circ} \mathrm{C}$ for 4 Hours. 


\section{LIST OF TABLES}

Table I. Preliminary INEEL HAW Stream Compositions.

Table II. Targeted Processing and Product Performance Criteria for INEEL HAW Glasses.

Table III. Elemental Release Values for the EA Glass via PCT.

Table IV. BL-1 Frit and 17.7 wt\% "All Blend" Target Glass Compositions.

Table V. Glass Compositions Used to Evaluate Various Alkali Effects.

Table VI. BL-2 Frit and 19.0 wt\% "All Blend" Target Glass Compositions.

Table VII. BL-3 Frit and 19.0 wt\% "All Blend" Target Glass Compositions.

Table VIII. Compositions of Frit \#1 (BL-4) and Frit \#2 (BL-5).

Table IX. Target Glass Compositions for BL-4 and BL-5.

Table X. $\quad$ PCT Results of BL-4 and BL-5.

Table XI. BL-6 Frit and 19.0 wt\% "All Blend" Target Glass Compositions.

Table XII. BL-7 Frit and 19.0 wt\% "All Blend" Target Glass Compositions.

Table XIII. Comparison of Total Alkali Distribution for BL-4, BL-5, BL-6, and BL-7.

Table XIV. BL-8 Frit and 19.0 wt\% "All Blend" Target Glass Compositions.

Table XV. $\quad$ PCT Results for BL-8.

Table XVI. BL-9 Frit and 19.0 wt\% "All Blend" Target Glass Compositions.

Table XVII. PCT Results for BL-9. 


\section{ABREVIATIONS}

BL Blend (representing the "All Blend" waste stream)

DWPF Defense Waste Processing Facility

ICPP Idaho Chemical Processing Plant

INEEL Idaho National Engineering and Environmental Laboratory

HAW High Activity Waste

LAW Low Activity Waste

PNNL Pacific Northwest National Laboratory

SRTC Savannah River Technology Center

$\mathrm{T}_{\mathrm{L}}$

Liquidus Temperature

TFA Tanks Focus Area

TTP Technical Task Plan 


\title{
Preliminary Glass Formulation Report for INEEL HAW
}

\author{
Technical Status Report \\ D.K. Peeler, J.D. Vienna, I.A. Reamer, and J.V. Crum
}

\subsection{Introduction}

For about four decades radioactive wastes have been collected and calcined from nuclear fuels reprocessing at the Idaho Chemical Processing Plant (ICPP). Over this time span, secondary radioactive wastes have also been collected and stored as liquid from decontamination, laboratory activities and fuels storage activities. The high activity waste (HAW) fractions generated by applying a separations process to these wastes will be of unique chemical compositions and will include new combinations of major components. In order to meet regulatory milestones in 2012, Idaho National Engineering and Environmental Laboratory (INEEL) must start Title I design for a facility designed to separate the radioactive waste into a high activity waste (HAW) and low activity waste (LAW) fractions in 2001. Therefore, in order to have a successful separation plant and meet INEEL regulatory milestones, technology development activities are required. One such requirement is the continual development of glass formulations for immobilization of INEEL HAW streams.

The overall strategy of this Tanks Focus Area (TFA) Technical Task Plan (TTP) ${ }^{1}$ is three fold:

(1) identify a glass forming system that optimizes properties and loadings of specific INEEL high activity waste streams,

(2) develop a glass composition region (or regions) to cover glasses from each individual waste streams (sodium bearing waste, Al-calcine, and/or Zr-calcine) or blending strategies (i.e., "All Blend") with adequate processing properties (viscosity, liquidus, and corrosion) and product performance criteria (durability), and

(3) support INEEL with glass formulation and testing expertise to assist in flow sheet optimization and melter demonstrations.

The FY98 glass formulation activities are focused on defining candidate glass compositions to be processed in INEEL's $1 / 4$ scale melter and defining an extended test matrix encompassing all of the INEEL wastes as currently defined. Piepel et al. [1] have documented the definition of the extended test matrix and its objectives. This report statuses the preliminary work being performed at the Savannah River Technology

\footnotetext{
${ }^{1}$ Tanks Focus Area (TFA) Technical Task Plans (TTP) SR1-6-WT-31 and PNNL-RL3-7-WT-31.
} 
Center (SRTC) and Pacific Northwest National Laboratory (PNNL) to support INEEL's effort to process simulated HAW in their $1 / 4$ scale melter. The primary objectives of these initial studies were consistent with the overall TTP strategy:

(1) identify a potential glass forming system compatible with INEEL HAW wastes,

(2) develop and evaluate various frit compositions in terms of waste loading, processing, and product performance characteristics for specific INEEL waste streams, and

(3) support INEEL with glass formulation and testing expertise to assist in flow sheet optimization and melter demonstrations.

It should be stated that the work described in this report is "scoping" in nature and only statuses the current INEEL glass formulation activities in support of future INEEL $1 / 4$ scale melter runs. Specifically the objective of this report is to show that immobilization via vitrification is a viable option for specific INEEL HAW streams. The glasses developed for this research are by no means optimized. The primary output of this report will be the recommendation of a glass composition for the initial $1 / 4$ scale melter run at INEEL. The results of these tests will also provide key information to aid in the selection of a pretreatment strategy. Development of glass formulations to immobilize INEEL HAW will parallel those used to develop glass compositions for other HAW, actinide feeds, LAW, mixed, and/or hazardous waste streams at SRTC and PNNL.

A team comprising experts in glass chemistry, glass technology, and statistics at both SRTC and PNNL performed this study. This joint effort combined the strengths of each discipline and site to quickly develop a glass formulation for a specific INEEL HAW. Because of this overlap, a large fraction of the information in this report is also found in an additional report [2].

\subsection{Preliminary INEEL Waste Stream Compositions}

Two primary inputs required for glass formulation are: (1) composition(s) of the incoming waste stream(s), and (2) targeted processing and product performance constraints (see Section 3.0). INEEL waste stream compositions were obtained during the initial INEEL HAW workshop ${ }^{2}$ and are based on specific pretreatment flow sheet assumptions. If flow sheet modifications are made, compositional changes to the feed stream may result. Therefore, initial definition of the waste stream compositions and variation should be based on "best guess" future flow sheet expectations. If significant pretreatment changes are made, overlap of the initially defined waste compositional space with future composition envelope definitions could be minimal. Data developed on the initial compositional envelope would therefore have limited applicability to the newly defined compositional space.

\footnotetext{
${ }^{2}$ Initial INEEL. Workshop was held at INEEL on 10/22 - 10/23, 1997 with representatives from NEEL, SRTC, and PNNL in attendance.
} 
It is recognized that the interface between glass formulation activities and development of pretreatment flow sheets should be an iterative process. That is, glass formulation personnel may identify a component from a particular stream that limits waste loading or consistently causes glasses to fall outside the predefined processing and/or product performance constraints envelope. Having identified a "troublesome" component, recommendations for pretreatment flow sheet changes to minimize this component would be made. The converse is also valid. That is, the pretreatment flow sheet may send "troublesome" components to immobilization due to ease of processing. This may require glass formulations to target lower waste loadings or adjust frit formulations. The key is a balanced interface between immobilization and pretreatment.

The INEEL HAW waste streams include:

- denitrated liquid HAW for sodium-bearing waste (SBW) with no resin or solids,

- denitrated liquid HAW for the Al-calcine with no resin or solids,

- denitrated liquid HAW for $\mathrm{Zr}$-calcine with no resin or solids, and

- solids and ion-exchange (IEX) resin.

Table I shows the INEEL waste streams in which the initial scoping studies were based. For the current flow sheet assumptions, each of the seven feed streams is "dominated" by various oxide components including $\mathrm{Al}_{2} \mathrm{O}_{3}, \mathrm{Cs}_{2} \mathrm{O}, \mathrm{K}_{2} \mathrm{O}, \mathrm{P}_{2} \mathrm{O}_{5}$, and $\mathrm{ZrO}_{2}$. If one considers the Al-calcine stream, $\mathrm{P}_{2} \mathrm{O}_{5}, \mathrm{~K}_{2} \mathrm{O}$, and $\mathrm{Cs}_{2} \mathrm{O}$ dominate this particular system (exceeding $90 \mathrm{wt} \%$ of the total). Zirconia dominates the $\mathrm{Zr}$-calcine stream (>92 wt\%), with $\mathrm{P}_{2} \mathrm{O}_{5}, \mathrm{~K}_{2} \mathrm{O}$ and $\mathrm{Al}_{2} \mathrm{O}_{3}$ comprising more than $96 \mathrm{wt} \%$ of the SBW stream. Immobilizing individual streams could result in different oxides limiting the waste loading, processing constraints, and/or performance criteria while blending may minimize the effects of dominant species which may retard glass forming ability.

The "All Blend" composition (shown in Table I) assumes that the SBW, Al-calcine, Zr-calcine, solids, and IEX resins are blended. Although physical location of the wastes may prohibit this blending strategy, the use of the "All Blend" composition provides an initial measure for glass formulation work. Even with blending, $\mathrm{ZrO}_{2}$ dominants the "All Blend" waste stream (approximately $80 \mathrm{wt} \%$ ) due to the large quantity of the $\mathrm{Zr}$-calcine waste stream relative to the other streams. Blending strategies and compositional consistency within and between stream(s) will play a major role in determining the targeted waste loading. It should also be noted that the "All Blend" composition has an advantage in terms of minimizing the effects of both $\mathrm{K}_{2} \mathrm{O}$ and $\mathrm{P}_{2} \mathrm{O}_{5}$ via dilution by the large volume $\mathrm{Zr}$-calcine stream.

Based on direction from INEEL, initial glass formulation efforts focused on the "All Blend" waste stream for "proof-of-principle" testing at the crucible scale. Again, the intent of these scoping studies is to demonstrate that immobilization via vitrification is a viable option for specific INEEL HAW streams. 
Subsequent testing, although limited, also evaluated the vitrification potential of the " $\mathrm{Zr}$-calcine" stream. This report discusses the scoping work performed only for the "All Blend" composition.

Table I. Preliminary INEEL HAW Stream Compositions.

(in wt \%)

\begin{tabular}{ccccccccc}
\hline Oxides & Al-cal & Al-sol & Zr-cal & $\mathrm{Zr}$-sol & SBW-cal & SBW-sol & IEX Res & All Blend \\
\hline $\mathrm{Al}_{2} \mathrm{O}_{3}$ & 1.09 & 100.00 & 0.01 & 38.00 & 0.16 & 100.00 & 0.00 & 8.90 \\
\hline $\mathrm{BaO}$ & 0.00 & 0.00 & 0.00 & 0.00 & 0.31 & 0.00 & 0.00 & 0.02 \\
\hline $\mathrm{CaO}$ & 0.00 & 0.00 & 0.02 & 9.30 & 0.01 & 0.00 & 0.00 & 0.45 \\
\hline $\mathrm{Cs}_{2} \mathrm{O}$ & 15.46 & 0.00 & 0.28 & 0.00 & 0.45 & 0.00 & 0.00 & 0.50 \\
\hline $\mathrm{CuO}$ & 0.00 & 0.00 & 0.00 & 0.00 & 0.00 & 0.00 & 31.98 & 0.36 \\
\hline $\mathrm{Fe}_{2} \mathrm{O}_{3}$ & 0.16 & 0.00 & 0.02 & 0.00 & 0.16 & 0.00 & 21.40 & 0.26 \\
\hline $\mathrm{Gd}_{2} \mathrm{O}_{3}$ & 0.00 & 0.00 & 0.45 & 0.00 & 0.00 & 0.00 & 0.00 & 0.36 \\
\hline $\mathrm{K}_{2} \mathrm{O}$ & 50.25 & 0.00 & 2.76 & 0.00 & 63.55 & 0.00 & 12.62 & 6.29 \\
\hline $\mathrm{MoO}_{3}$ & 0.00 & 0.00 & 0.00 & 0.00 & 0.92 & 0.00 & 0.00 & 0.05 \\
\hline $\mathrm{Na}_{2} \mathrm{O}$ & 0.03 & 0.00 & 0.00 & 0.00 & 0.00 & 0.00 & 0.00 & 0.00 \\
\hline $\mathrm{P}_{2} \mathrm{O}_{5}$ & 25.24 & 0.00 & 1.39 & 0.00 & 28.59 & 0.00 & 0.00 & 2.93 \\
\hline $\mathrm{PbO}^{2}$ & 0.00 & 0.00 & 0.00 & 0.00 & 0.25 & 0.00 & 0.00 & 0.01 \\
\hline $\mathrm{SiO}_{2}$ & 0.00 & 0.00 & 0.00 & 0.00 & 0.00 & 0.00 & 34.00 & 0.38 \\
\hline $\mathrm{SrO}^{2}$ & 2.48 & 0.00 & 0.05 & 0.00 & 0.01 & 0.00 & 0.00 & 0.08 \\
\hline TruO & 5.29 & 0.00 & 0.14 & 0.00 & 2.63 & 0.00 & 0.00 & 0.33 \\
\hline $\mathrm{ZrO}_{2}$ & 0.00 & 0.00 & 94.89 & 52.70 & 2.96 & 0.00 & 0.00 & 79.09 \\
\hline $\mathrm{Total}_{2}$ & 100.0 & 100.0 & 100.0 & 100.0 & 100.0 & 100.0 & 100.0 & 100.0 \\
\hline $\mathrm{waste}$ & 1.6 & 0.001 & 80.6 & 4.7 & 4.9 & 7.1 & 1.1 & 100.0 \\
\hline
\end{tabular}

\subsection{Primary Processing and Product Performance Criteria}

Two types of melt and glass property limitations are of concern in this study: (1) those required for melter processability, and (2) those required by the Waste Acceptance Product Specifications (WAPS) [3] for product acceptance of the glass. Melter processing requirements are dependent upon the melter type but in general relate to glass viscosity, liquidus temperature, and electrical conductivity. The WAPS impose limitations on glass durability as measured by ASTM-C-1285-94 (Product Consistency Test (PCT)) [4] and insist that chemical and phase stability information be reported. For the initial INEEL tests, it is assumed that the targeted processing and product performance property constraints are the "standard" high-level waste criteria currently being used at the Defense Waste Processing Facility (DWPF). It should be noted that all information required by the WAPS is not being evaluated in this study. Only those primary processing and product performance issues considered essential to glass formulation and melter processing 
were addressed in this study. The targeted processing and product constraints for INEEL glasses are listed in Table II.

Table II. Targeted Processing and Product Performance Criteria for INEEL HAW Glasses.

\begin{tabular}{cc}
\hline Property & Criteria \\
\hline Viscosity & $\geq 20$ Poise, $<100$ Poise at $1150^{\circ} \mathrm{C}$ \\
Liquidus Temperature & $<1050^{\circ} \mathrm{C}$ \\
Normalized B, Na, and & $2 \sigma$ lower than those of the \\
Li Release Via PCT & Environmental Assessment (EA) glass \\
\hline
\end{tabular}

\subsection{Viscosity}

The viscosity of the waste glass should be between 20 and 100 Poise ( $2-10$ Pass) at the nominal melter operating temperature (assumed to be $1150^{\circ} \mathrm{C}$ for the INEEL melter). Maintaining the glass viscosity within this "acceptable" range reduces technical risks associated with processing. Glasses with a lower viscosity tend to accelerate corrosion of the melter materials of construction and inhibit cold cap formation which can lead to an increased volatility from the melt pool. Glass with higher viscosity may translate into slower melting rates and pouring difficulties.

\subsection{Liquidus Temperature}

The highest temperature at which the melt is in equilibrium with the primary crystalline phase is called the liquidus temperature $\left(T_{L}\right)$. This study adopted the DWPF criterion for $T_{L}$, which specifies an upper limit of $1050^{\circ} \mathrm{C}$. Only minor crystalline phases such as insoluble noble metals or their oxides should be present above $1050^{\circ} \mathrm{C}$. This constraint is based on an assumption that the nominal operating temperature of the INEEL melter is $1150^{\circ} \mathrm{C}$ with an imposed $100^{\circ} \mathrm{C}$ "safety" margin. This margin allows for process upsets and for idling of the melter at lower temperatures for short times to facilitate repairs thus reducing the technical risks of devitrification within the melter and subsequent potential processing problems. The presence of insoluble and residual solid phases (i.e., crystallization) may increase the rate at which a sludge forms on the bottom of the melter, clog areas within the melter, possibly short melter electrodes (if the phases are conductive), and/or prevent Joule heating (if the phases are insulating).

\subsection{Durability}

Sections 3.1 and 3.2 described constraints designed to reduce the technical risks of processing the glass through the melter system. The third major constraint that will be evaluated in these initial studies is related to product acceptance as required by the WAPS. The WAPS impose limitations on durability as measured by the Product Consistency Test (PCT). The WAPS requires that the normalized releases of 
boron, lithium, and sodium as determined by the PCT be $2 \sigma$ less than the releases of these elements from the DWPF Environmental Assessment (EA) glass. The elemental release values for the EA glass are listed in Table III.[5] The normalized release values are in the units $\mathrm{g} / \mathrm{L}$, which involves normalizing for the concentration of an element in the glass, but not for the surface area to volume ratio (A/V). Although the use of the EA glass is a preliminary target, a more realistic goal is to produce INEEL HAW glasses that are as durable as "typically high-level waste glasses" developed for DWPF and Hanford as defined by the PCT. Based on boron release, standard high-level waste glasses are approximately one order of magnitude more durable than the EA glass.

Table III. Elemental Release Values for the EA Glass via PCT.[5]

\begin{tabular}{|c|c|c|c|}
\cline { 2 - 4 } \multicolumn{1}{c|}{} & \multicolumn{3}{c|}{ Leachate Concentrations } \\
\cline { 2 - 4 } & $\mathrm{B}(\mathrm{g} / \mathrm{L})$ & $\mathrm{Li}(\mathrm{g} / \mathrm{L})$ & $\mathrm{Na}(\mathrm{g} / \mathrm{L})$ \\
\hline $\mathrm{Mean}^{3}$ & 16.695 & 9.565 & 13.346 \\
\hline
\end{tabular}

\subsection{Experimental}

\subsection{Batching and Melting}

Batches were prepared to make between 50 and 350 grams of glass using standard batching and melting procedures.[6-8] Reagent grade oxides and carbonates were used as the raw material sources. Batch materials were weighed to the nearest hundredth of a gram and thoroughly mixed. The well mixed batch was placed into a Pt- $10 \% \mathrm{Rh}$ crucible and processed at $1150^{\circ} \mathrm{C}$. In some cases the glasses were melted for 4 hours continuously [6] and in others melted for 1 hour, quenched, ground in a WC mill for 4-6 minutes and remelted for 1 hour [8]. The crucible was removed from the high temperature furnace and the glass was poured onto a stainless steel quench plate producing a glass patty. Glass remaining in the crucible was broken out (referred to throughout this report as "residual crucible glass") and archived with the pour patty for further evaluation or testing.

\subsection{Homogeneity}

Visual observations regarding homogeneity of the pour patty and residual crucible glass were recorded in the appropriate laboratory notebook(s) ${ }^{4}$. Homogeneity is defined throughout this report by the presence of only one phase (i.e., glass). The presence of undissolved $\mathrm{ZrO}_{2}$ (the likely candidate for the "All Blend" glasses) was deemed unacceptable. Optical microscopy, X-ray diffraction (XRD) and/or scanning electron microscopy (SEM) with energy dispersive spectroscopy (EDS) were used to confirm visual observations. It is important that both the pour patty and the residual crucible glass be evaluated prior to making a

\footnotetext{
${ }^{3}$ Mean calculated as the mean of the means given in reference 5 .

${ }^{4}$ SRTC and PNNL laboratory notebooks identified as WSRC-NB-95-299 and PNNL-54544.
} 
determination on homogeneity. The residual crucible glass will have a higher probability of containing undissolved material due to the settling potential resulting from density differences.

\subsection{Viscosity}

A formal high-temperature viscosity measurement was not performed for all glasses (i.e., only selected glasses). Viscosity was measured by a rotating spindle technique and evaluated using standard viscosity measurement procedures.[9] For those glasses in which a "formal" measurement was not made, visual observations were recorded during the pour. Previous experience with high-level waste glasses at both SRTC and PNNL allows experienced personnel to estimate viscosity of similar systems as a relative measure. High temperature viscosity measurements should be performed and/or confirmed by INEEL prior to running a recommended glass in the scaled melter.

\subsection{Liquidus Temperature Constraint}

The standard high-level waste liquidus temperature $\left(T_{L}\right)$ constraint requires the $T_{L}$ to be less than $1050^{\circ} \mathrm{C}$ (or $100^{\circ} \mathrm{C}$ below the nominal melt temperature assumed to be $1150^{\circ} \mathrm{C}$ for INEEL). To determine if the INEEL glasses met this constraint, a "uniform temperature" method was utilized. Each glass was isothermally held at $1050^{\circ} \mathrm{C}$ for 24 hours within a small Pt crucible with lid. The presence (or absence) of a primary crystalline phase was determined by visual observation with confirmation via optical microscopy, $\mathrm{XRD}$ and/or SEM/EDS. Note a "true" $\mathrm{T}_{\mathrm{L}}$ was not determined for all glasses. In most cases, the only objective was to determine if the specific glass met the $<1050^{\circ} \mathrm{C}$ constraint.

\subsection{Durability}

Chemical durability of "candidate" INEEL HAW glasses was determined by the Product Consistency Test (PCT) [4]. Since the PCT is a standard test to evaluate the durability of waste glasses, the dissolution behavior of the INEEL HAW glasses can be compared to glasses developed for DWPF, Hanford, and West Valley. The PCT requires crushed glass of a particle size between 75 and 150 microns $(-100$ to +200 mesh). The crushed glass is cleaned and dried. A pre-determined amount of glass is added to deionized water to target a $10 \mathrm{~mL} / \mathrm{g}$ solution volume to glass mass ratio. The vessels are then placed into an isothermal oven at $90^{\circ} \mathrm{C} \pm 2^{\circ} \mathrm{C}$ for seven days. The initial and final $\mathrm{pH}$ of the solution are recorded and aliquots of the solution are filtered and submitted for ICP analysis. In this study, PCT results are reported as normalized elemental mass releases calculated based on "as-batched" compositions. The normalized release values are in the units $\mathrm{g} / \mathrm{L}$, which involves normalizing for the concentration of an element in the glass, but not for the surface area to volume ratio $(\mathrm{A} / \mathrm{V})$. The release values obtained were compared to the Environmental Assessment (EA) glass. PNNL performed duplicate testing of each glass while SRTC performed the PCT in triplicate. 


\subsection{Glass Form Development Studies}

\subsection{Initial Scoping Studies}

Based on a recommendation from INEEL, initial glass formulation activities were to focus on the "All Blend" composition for "proof-of-concept". As discussed in Section 2.0, this specific stream is dominated by $\mathrm{ZrO}_{2}$, which should ultimately limit the waste loading. A brief literature survey and review of high $\mathrm{ZrO}_{2}$-containing glasses both at PNNL and SRTC resulted in a relatively limited data set. ${ }^{5}$

\subsubsection{BL-1 Frit}

Using models based on limited high $\mathrm{ZrO}_{2}$ data, the BL-1 frit was developed for the "All Blend" waste stream. Table IV shows the frit composition and a targeted 17.7 wt\% "All Blend" loading glass (i.e., 14 $w \% \mathrm{ZrO}_{2}$ in glass). Initial fabrication of $\mathrm{BL}-1$ at $1150^{\circ} \mathrm{C}$ resulted in a visually homogeneous glass indicating complete dissolution of all waste oxide components (i.e., no detection of undissolved $\mathrm{ZrO}_{2}$ ). Optical microscopy was used to confirm visual observations of homogeneity.

$T_{L}$ and viscosity were also evaluated for this glass. The liquidus temperature exceeded the $1050^{\circ} \mathrm{C}$ target $\left(>1100^{\circ} \mathrm{C}\right.$ ). At $1150^{\circ} \mathrm{C}$, the viscosity of the system was measured to be 95 Poise (9.5 Pass) which, although is within the targeted range is relatively high (probably as a result of the high $\mathrm{ZrO}_{2}$ content within the glass coupled with a relatively low alkali content Arrhenius coefficients $\left(\ln \eta=A+B / T_{0}\right)$ for the BL-1 viscosity curve are: $A=-13.387$ and $B=22,253.1 \mathrm{~K}$.

It was anticipated that the distribution of alkali and/or the specific alkali(s) used could have an impact on the solubility of $\mathrm{ZrO}_{2}$ as well as other processing properties. To address this issue, four glasses were prepared based on the BL-1 frit composition that varied in alkali additions. Separate additions ( $2 \mathrm{wt} \%$ ) of $\mathrm{Na}_{2} \mathrm{O}, \mathrm{Li}_{2} \mathrm{O}$, and $\mathrm{K}_{2} \mathrm{O}$ to the homogeneous $\mathrm{BL}-1$ glass composition resulted in three "alkali-rich" glasses (BL-1Na, BL-1Li, and BL-1K). A fourth glass (BL-1R) was also tested being a remelt of BL-1. These glass compositions are summarized in Table V.

\footnotetext{
${ }^{5}$ The results of the literature review will be documented elsewhere.
} 
Table IV. BL-1 Frit and 17.7 wt\% "All Blend" Target Glass Compositions.

\begin{tabular}{|c|c|c|c|}
\hline Oxide & "All Blend" & BL-1 Frit & BL-1 Glass \\
\hline $\mathrm{Al}_{2} \mathrm{O}_{3}$ & 8.9 & 2.99 & 4.04 \\
\hline $\mathrm{B}_{2} \mathrm{O}_{3}$ & - & 6.08 & 5.0 \\
\hline $\mathrm{BaO}$ & 0.02 & - & - \\
\hline $\mathrm{CaO}$ & 0.45 & - & 0.08 \\
\hline $\mathrm{Cs} 2 \mathrm{O}$ & 0.5 & - & 0.15 \\
\hline $\mathrm{CuO}$ & 0.36 & - & 0.06 \\
\hline $\mathrm{Fe}_{2} \mathrm{O}_{3}$ & 0.26 & - & 0.05 \\
\hline $\mathrm{Gd}_{2} \mathrm{O}_{3}$ & 0.36 & - & 0.06 \\
\hline $\mathrm{K}_{2} \mathrm{O}$ & 6.29 & - & 1.11 \\
\hline $\mathrm{Li}_{2} \mathrm{O}$ & - & 6.11 & 5.03 \\
\hline $\mathrm{MoO}_{3}$ & 0.05 & - & 0.01 \\
\hline $\mathrm{Na}_{2} \mathrm{O}$ & - & 22.81 & 18.77 \\
\hline $\mathrm{P}_{2} \mathrm{O}_{5}$ & 2.93 & - & 0.52 \\
\hline $\mathrm{PbO}$ & 0.01 & - & - \\
\hline $\mathrm{SiO}_{2}$ & 0.38 & 62.01 & 51.01 \\
\hline $\mathrm{SrO}_{2} \mathrm{O}$ & 0.08 & - & 0.01 \\
\hline $\mathrm{CeO}_{2}$ & 0.33 & - & 0.01 \\
\hline $\mathrm{ZrO}_{2}$ & 79.09 & - & 14.00 \\
\hline $\mathrm{Lading}$ & - & - & $17.7 \%$ \\
\hline & & & \\
\hline
\end{tabular}


Table V. Glass Compositions Used to Evaluate Various Alkali Effects.

\begin{tabular}{|c|c|c|c|c|}
\hline Oxide & $\begin{array}{c}\text { BL-1 (BL-1R) } \\
\text { (Remelt) }\end{array}$ & $\begin{array}{c}\text { BL-1Li } \\
2 \mathrm{wt} \% \mathrm{Li}_{2} \mathrm{O}\end{array}$ & $\begin{array}{c}\mathrm{BL}-1 \mathrm{Na} \\
2 \mathrm{wt} \% \mathrm{Na}_{2} \mathrm{O}\end{array}$ & $\begin{array}{c}\text { BL-1K } \\
2 \mathrm{wt} \% \mathrm{~K}_{2} \mathrm{O}\end{array}$ \\
\hline $\mathrm{Al}_{2} \mathrm{O}_{3}$ & 4.04 & 3.96 & 3.96 & 3.96 \\
\hline $\mathrm{B}_{2} \mathrm{O}_{3}$ & 5.00 & 4.90 & 4.90 & 4.90 \\
\hline $\mathrm{CaO}$ & 0.08 & 0.08 & 0.08 & 0.08 \\
\hline $\mathrm{CeO}_{2}$ & 0.01 & 0.01 & 0.01 & 0.01 \\
\hline $\mathrm{Cs}_{2} \mathrm{O}$ & 0.15 & 0.15 & 0.15 & 0.15 \\
\hline $\mathrm{CuO}$ & 0.06 & 0.06 & 0.06 & 0.06 \\
\hline $\mathrm{Fe}_{2} \mathrm{O}_{3}$ & 0.05 & 0.05 & 0.05 & 0.05 \\
\hline $\mathrm{Gd}_{2} \mathrm{O}_{3}$ & 0.06 & 0.06 & 0.06 & 0.06 \\
\hline $\mathrm{K}_{2} \mathrm{O}$ & 1.09 & 1.09 & 1.09 & 3.09 \\
\hline $\mathrm{Li}_{2} \mathrm{O}$ & 5.03 & 6.93 & 4.93 & 4.93 \\
\hline $\mathrm{MoO}_{3}$ & 0.01 & 0.01 & 0.01 & 0.01 \\
\hline $\mathrm{Na}_{2} \mathrm{O}$ & 18.77 & 18.39 & 20.39 & 18.39 \\
\hline $\mathrm{P}_{2} \mathrm{O}_{5}$ & 0.51 & 0.51 & 0.51 & 0.51 \\
\hline $\mathrm{SiO}_{2}$ & 51.10 & 50.08 & 50.08 & 50.08 \\
\hline SrO & 0.01 & 0.01 & 0.01 & 0.01 \\
\hline $\mathrm{ZrO}_{2}$ & 14.00 & 13.72 & 13.72 & 13.72 \\
\hline $\mathrm{T}_{\mathrm{L}}\left({ }^{\circ} \mathrm{C}\right)$ & $>1050$ & $>1050$ & $>1050$ & $>1050$ \\
\hline
\end{tabular}

Fabrication of these four glasses at $1150^{\circ} \mathrm{C}$ produced homogeneous systems by visuall observations which were confirmed by optical microscopy. Based on visual observations and comparison with other highlevel waste glasses processed at similar temperatures, the viscosity of these glasses should be within the propcesšing constraints of $20-100$ Poise at $1150^{\circ} \mathrm{C}$. A "formal" high temperature viscosity curve was not performed to confirm these semi-quantitative, visual observations. The liquidus temperature constraint was evaluated by heat treating these samples at $1050^{\circ} \mathrm{C}$ for 24 hours. All four glasses had liquidus temperatures exceeding the $1050^{\circ} \mathrm{C}$ constraint (in fact all $\mathrm{T}_{\mathrm{L}}$ 's exceeded $1100^{\circ} \mathrm{C}$ ). However, there were dramatic differences in the degree of crystallization associated with these systems. BL-1 Li ( $2 \mathrm{wt} \% \mathrm{Li}_{2} \mathrm{O}$ addition to BL-1) had a dramatic reduction in the percent crystallization relative to BL-1 or BL-1R (remelt of BL-1). ${ }^{6}$ Although the $T_{L}$ was greater than $1100^{\circ} \mathrm{C}$, only a few scattered crystals were observed in BL-1Li. BL-1Na

\footnotetext{
${ }^{6}$ The remelt $(B L-1 R)$ only confirmed initial observations that $T_{L}$ exceeded $1050^{\circ} \mathrm{C}\left(>1100^{\circ} \mathrm{C}\right)$ with a similar degree of crystallization as BL-1.
} 
( $2 \mathrm{wt} \% \mathrm{Na}_{2} \mathrm{O}$ ) and $\mathrm{BL}-1 \mathrm{~K}\left(2 \mathrm{wt} \% \mathrm{~K}_{2} \mathrm{O}\right.$ ) had fewer crystals relative to BL-1 (and BL-1R) but the reduction was not as dramatic as that observed with the $2 \mathrm{wt} \% \mathrm{Li}_{2} \mathrm{O}$ addition. These results suggest that $\mathrm{Li}_{2} \mathrm{O}$ additions may effectively reduce $T_{L}$ for this particular glass system and/or waste stream. However, $T_{L}$ is only one of several constraints to be met. PCT's were not evaluated on these glasses due to nonconformance with the $T_{L}$ constraint.

\subsubsection{BL-2 Frit}

Based on the observations of $\mathrm{BL}-1 \mathrm{Li}$ (i.e., $\mathrm{Li}_{2} \mathrm{O}$ additions may decrease $\mathrm{T}_{\mathrm{L}}$ ), BL-2 was formulated. This particular glass composition increased the $\mathrm{Li}_{2} \mathrm{O}$ concentration to 7 wt\% in glass while removing the $\mathrm{Al}_{2} \mathrm{O}_{3}$ from the BL-1 frit composition. Table VI summarizes the BL-2 frit composition and a target $19.0 \mathrm{wt} \%$ "All Blend" glass (translating into approximately $15.0 \mathrm{wt} \% \mathrm{ZrO}_{2}$ in glass). ${ }^{7}$ This glass was melted at $1150^{\circ} \mathrm{C}$ and was visually homogeneous. Optical microscopy confirmed visual observations of homogeneity.

Table VI. BL-2 Frit and 19.0 wt\% “All Blend" Target Glass Compositions.

\begin{tabular}{cccc}
\hline Oxide & "All Blend" & BL-2 Frit & BL-2 Glass \\
\hline $\mathrm{Al}_{2} \mathrm{O}_{3}$ & 8.9 & - & 1.69 \\
$\mathrm{~B}_{2} \mathrm{O}_{3}$ & - & 6.17 & 5.0 \\
$\mathrm{BaO}$ & 0.02 & - & - \\
$\mathrm{CaO}$ & 0.45 & - & 0.09 \\
$\mathrm{Cs} \mathrm{O}_{2}$ & 0.5 & - & 0.09 \\
$\mathrm{CuO}$ & 0.36 & - & 0.07 \\
$\mathrm{Fe}_{2} \mathrm{O}_{3}$ & 0.26 & - & 0.05 \\
$\mathrm{Gd}_{2} \mathrm{O}_{3}$ & 0.36 & - & 0.07 \\
$\mathrm{~K}_{2} \mathrm{O}$ & 6.29 & - & 1.20 \\
$\mathrm{Li}_{2} \mathrm{O}$ & - & 8.64 & 7.00 \\
$\mathrm{MoO}_{3}$ & 0.05 & - & 0.01 \\
$\mathrm{Na}_{2} \mathrm{O}$ & - & 20.83 & 16.87 \\
$\mathrm{P}_{2} \mathrm{O}_{5}$ & 2.93 & - & 0.56 \\
$\mathrm{PbO}_{\mathrm{SOO}}$ & 0.01 & - & - \\
$\mathrm{SiO}_{2}$ & 0.38 & 64.36 & 52.20 \\
$\mathrm{SrO}_{\mathrm{CeO}}$ & 0.08 & - & 0.01 \\
$\mathrm{ZrO}_{2}$ & 0.33 & - & 0.06 \\
$\mathrm{Loading}$ & 79.09 & - & 15.03 \\
\hline
\end{tabular}

\footnotetext{
${ }^{7}$ Not only was the frit composition changed but also the target loading increased as compared to BL-2.
} 
The 24 hour isothermal liquidus temperature measurement resulted in the formation of a crystalline phase indicating that the $1050^{\circ} \mathrm{C}$ constraint was exceeded. The measured $\mathrm{T}_{\mathrm{L}}$ for $\mathrm{BL}-2$ was $1077^{\circ} \mathrm{C}$ (no crystals found at $1080^{\circ} \mathrm{C}$ and while a few were found at $1074^{\circ} \mathrm{C}$ ). $\mathrm{Na}_{2} \mathrm{ZrSi}_{2} \mathrm{O}_{7}$ was identified as the primary crystalline phase by XRD. It should be noted that although the $\mathrm{Li}_{2} \mathrm{O}$ concentration for this glass was increased in an attempt to reduce the $\mathrm{T}_{\mathrm{L}}$ relative to $\mathrm{BL}-1$ and/or $\mathrm{BL}-1 \mathrm{Li}$, the relative waste loading increased (from $17.7 \mathrm{wt} \%$ to $19.0 \mathrm{wt} \%$ ). Increasing the waste loading increases the $\mathrm{ZrO}_{2}$ content in the final glass. $\mathrm{T}_{\mathrm{L}}$ for the "All Blend" based-glasses appears to be directly related to waste loading or $\mathrm{ZrO}_{2}$ content. For BL-2, increased additions of $\mathrm{Li}_{2} \mathrm{O}$ appear to reduce the $\mathrm{T}_{\mathrm{L}}$ of the "All Blend" glasses (i.e., the measured $\mathrm{T}_{\mathrm{L}}$ of $1077^{\circ} \mathrm{C}$ is approaching the $1050^{\circ} \mathrm{C}$ constraint). It should be noted that although "improved" processing constraints may be achieved through higher $\mathrm{Li}_{2} \mathrm{O}$ concentrations (i.e., $\mathrm{T}_{\mathrm{L}}$ ), the impact on product performance (e.g., durability) was not evaluated.

\subsubsection{BL-3 Frit}

Development and evaluation of the BL-3 frit was performed in parallel with BL-2. The target "All Blend" waste loading was 19.0 wt\% with no $\mathrm{Al}_{2} \mathrm{O}_{3}$ addition from the frit. For $\mathrm{BL}-3$, the $\mathrm{Na}_{2} \mathrm{O}$ and $\mathrm{Li}_{2} \mathrm{O}$ concentrations were increased to 22 and $4.6 \mathrm{wt} \%$, respectively in glass relative to BL-2. Table VII summarizes the frit and target glass compositions.

Although this glass had a relatively high alkali concentration, undissolved material (presumably $\mathrm{ZrO}_{2}$ ) was visually observed in the residual crucible glass after melting at $1200^{\circ} \mathrm{C}$. The "All Blend" glasses seem to be in the sodium-zircon silicate (and possibly $\mathrm{ZrO}_{2}$ ) primary phase field region. Therefore, higher $\mathrm{Na}$ levels in the glass translate to higher $\mathrm{T}_{\mathrm{L}}$. Increasing $\mathrm{Li}_{2} \mathrm{O}$ does not appear to lead to the same problem. 
Table VII. BL-3 Frit and 19.0 wt\% "All Blend" Target Glass Compositions.

\begin{tabular}{cccc}
\hline Oxide & $\begin{array}{c}\text { "All } \\
\text { Blend" }\end{array}$ & BL-3 Frit & BL-3 Glass \\
\hline $\mathrm{Al}_{2} \mathrm{O}_{3}$ & 8.9 & - & 1.69 \\
$\mathrm{~B}_{2} \mathrm{O}_{3}$ & - & 6.17 & 5.0 \\
$\mathrm{BaO}$ & 0.02 & - & - \\
$\mathrm{CaO}$ & 0.45 & - & 0.09 \\
$\mathrm{Cs} \mathrm{O}_{2}$ & 0.5 & - & 0.09 \\
$\mathrm{CuO}$ & 0.36 & - & 0.07 \\
$\mathrm{Fe}_{2} \mathrm{O}_{3}$ & 0.26 & - & 0.05 \\
$\mathrm{Gd}_{2} \mathrm{O}_{3}$ & 0.36 & - & 0.07 \\
$\mathrm{~K}_{2} \mathrm{O}$ & 6.29 & - & 1.20 \\
$\mathrm{Li}_{2} \mathrm{O}$ & - & 5.71 & 4.63 \\
$\mathrm{MoO}_{3}$ & 0.05 & - & 0.01 \\
$\mathrm{Na}_{2} \mathrm{O}$ & - & 27.16 & 22.00 \\
$\mathrm{P}_{2} \mathrm{O}_{5}$ & 2.93 & - & 0.56 \\
$\mathrm{PbO}$ & 0.01 & - & - \\
$\mathrm{SiO}_{2}$ & 0.38 & 60.96 & 49.45 \\
$\mathrm{SrO}_{\mathrm{CeO}}$ & 0.08 & - & 0.01 \\
$\mathrm{CeO}_{2}$ & 0.33 & - & 0.06 \\
$\mathrm{ZrO}_{2}$ & 79.09 & - & 15.03 \\
$\mathrm{Laading}$ & - & & $19 \%$ \\
\hline & & & \\
\hline
\end{tabular}

\subsubsection{Summary of Initial Scoping Studies}

Fabrication of the initial "All Blend" glasses has provided a knowledge base for future formulation work. Relatively high loadings of the "All Blend" waste stream were achieved in these initial glasses. Complete dissolution of up to $15 \mathrm{wt} \% \mathrm{ZrO}_{2}$ has been demonstrated. However, waste loadings for this system will be limited by the high $\mathrm{ZrO}_{2}$ content. Although these glasses were homogeneous upon initial fabrication at $1150^{\circ} \mathrm{C}$, the high $\mathrm{ZrO}_{2}$ content lead to the formation of a $\mathrm{Zr}$-containing primary crystalline phase when heat treated at $1050^{\circ} \mathrm{C}$ for 24 hours thus failing to pass the $1050^{\circ} \mathrm{C}$ liquidus temperature constraint. Production of non-homogeneous glass melts (i.e., incomplete dissolution of $\mathrm{ZrO}_{2}$ ) when processed at $1150^{\circ} \mathrm{C}$ for $2-4$ hours and/or glasses exceeding the $1050^{\circ} \mathrm{C} \mathrm{T}_{\mathrm{L}}$ constraint are the two primary processing concerns for these high $\mathrm{Zr}$-containing glasses. Based on a series of glasses fabricated with varying alkali oxides, it appears that $\mathrm{Li}_{2} \mathrm{O}$ has a marked advantage over both $\mathrm{Na}_{2} \mathrm{O}$ and $\mathrm{K}_{2} \mathrm{O}$ in lowering $\mathrm{T}_{\mathrm{L}}$. Although 2 wt\% additions of $\mathrm{Li}_{2} \mathrm{O}$ (BL-1Li) did reduce the volume of crystallization relative to $\mathrm{BL}-1$ at $1050^{\circ} \mathrm{C}$, the $\mathrm{T}_{\mathrm{L}}$ constraint was still exceeded. The higher alkali concentrations may also have a negative impact on product performance - a parameter not evaluated as of yet. 


\section{$5.2 \quad B L-4$ and $B L-5$}

Based on a limited data set of high- $\mathrm{ZrO}_{2}$ containing borosilicate glasses and previous experience with the "All Blend" waste streams (Section 5.1), two additional frit compositions were developed. Development efforts were aided by determining the effect of composition on predicted property differentials from a known point. That is, since initial model predictions for absolute properties are suspect as a result of the limited database, property differentials were estimated from a known point (e.g., measured $T_{L}$ of $1077^{\circ} \mathrm{C}$ for BL-2). Tables VIII and IX show the frit and target glass compositions for BL-4 (18.3 wt\% "All Blend" loading) and BL-5 (19.0 wt\% "All Blend" loading), respectively. These were the first two glasses seriously considered for recommendation to INEEL in support of the $1 / 4$ scale melter run. Therefore, both the primary processing and product performance criteria were evaluated for these two candidate glasses as well as additional testing related to melter processing (devitrification potential and "redissolution" tests, see Section 5.6).

Table VIII. Compositions of Frit \#1 (BL-4) and Frit \#2 (BL-5).

\begin{tabular}{ccc}
\hline Oxide & Frit \#1 & Frit \#2 \\
\hline $\mathrm{B}_{2} \mathrm{O}_{3}$ & 6.1 & 6.2 \\
$\mathrm{Li}_{2} \mathrm{O}$ & 8.6 & 9.9 \\
$\mathrm{Na}_{2} \mathrm{O}$ & 20.8 & 19.8 \\
$\mathrm{SiO}_{2}$ & 64.5 & 64.2 \\
\hline
\end{tabular}

The main difference between the two frit compositions is distribution of the alkali content. Both frits have relatively high total alkali contents of approximately $29.5 \mathrm{wt} \%$. Frit $\# 2$ has a slightly higher $\mathrm{Li}_{2} \mathrm{O}$ content relative to Frit \#1. Based on limited data, literature studies, and previous testing with high $\mathrm{Zr}$-containing glasses, increased alkali content (in particular $\mathrm{Li}_{2} \mathrm{O}$ ) may enhance the solubility of $\mathrm{ZrO}_{2}$ (which dominates the "All Blend" waste stream). It is anticipated that there will be a balance between maximizing the solubility of the "All Blend" waste stream by increasing the frit alkali content and maintaining structural integrity of the final product (chemical durability). It is well known that the high alkali content could result in a rapid increase in the solution $\mathrm{pH}$ by ion exchange resulting in enhance matrix dissolution.[10] Hawever, durable borosilicate glasses (based on PCT results) with 20-25 wt\% $\mathrm{Na}_{2} \mathrm{O}$ have been fabricated at PNNL and SRTC.[11-13]

\subsubsection{Results of Primary Processing and Product Performance Constraints}

\subsubsection{Homogeneity}

Initial fabrication of $\mathrm{BL}-4$ and $\mathrm{BL}-5$ at $1150^{\circ} \mathrm{C}$ resulted in homogeneous glass. Visual observations of each glass indicated complete dissolution of all waste oxide components (i.e., no detection of undissolved $\mathrm{ZrO}_{2}$ in either glass). Both glasses were blue in color (as were all BL glasses) probably due to the small concentration of $\mathrm{CuO}$ in the waste. 
A sample from both the pour patty and the residual crucible glass were submitted to XRD to confirm visual observations. Figures 1 and 2 show the XRD patterns obtained from the pour patty and residual crucible glass of BL-4 and BL-5, respectively. The presence of an amorphous hump (or absence of well defined peaks) indicates that the samples are homogeneous and contain no undissolved raw materials at or below the detection limit of the XRD unit (approximately $0.3-0.5 \mathrm{wt} \%$ based on the XRD run parameters). All $\mathrm{ZrO}_{2}$ was completely dissolved into these two glasses indicating that "All Blend" loadings of 18.3 and 19.0 wt $\%$ can be completely incorporated into the two respective frit compositions. ${ }^{8}$ These loadings translate into fairly significant $\mathrm{ZrO}_{2}$ levels in the final glass (approximately 14.5 and $15.0 \mathrm{wt} \%$ respectively).

\subsubsection{Viscosity}

Based on visual observations and comparison with other high-level waste glasses processed at similar temperatures, the viscosity of both glasses should be within the processing constraints of $20-100$ Poise at $1150^{\circ} \mathrm{C}$. A "formal" high temperature viscosity curve was not performed to confirm these semiquantitative, visual observations.

\subsubsection{Liquidus Temperature Constraint}

Both BL-4 and BL-5 were isothermally heat treated at $1050^{\circ} \mathrm{C}$ for 24 hours. Based on visual observations, both samples were void of crystallization indicating that the $T_{L}$ for both systems is below $1050^{\circ} \mathrm{C}$. XRD patterns for these two samples are shown in Figures 3 and 4. Based on the presence of the amorphous hump (or lack of well defined peaks), XRD confirms visual observations at the XRD detection limit. Therefore, both glass systems met the targeted $T_{L}$ constraint $\left(<1050^{\circ} \mathrm{C}\right)$ although the $T_{L}$ has not been defined for either system.

\footnotetext{
${ }^{8}$ Although maximum loadings have not been determined for these two glasses, the higher $\mathrm{Li}_{2} \mathrm{O}$ content frit $(\# 2)$ has successfully incorporated a higher "All Blend" loading.
} 
Table IX. Target Glass Compositions for BL-4 and BL-5.

(in wt \%)

\begin{tabular}{|c|c|c|c|}
\hline Oxide & "All Blend" & $\overline{B L-4}$ & BL-5 \\
\hline $\mathrm{Al}_{2} \mathrm{O}_{3}$ & 8.9 & 1.63 & 1.69 \\
\hline $\mathrm{B}_{2} \mathrm{O}_{3}$ & - & 5.0 & 4.99 \\
\hline $\mathrm{BaO}$ & 0.02 & - & - \\
\hline $\mathrm{CaO}$ & 0.45 & 0.09 & 0.09 \\
\hline $\mathrm{Cs}_{2} \mathrm{O}$ & 0.5 & 0.09 & 0.09 \\
\hline $\mathrm{CuO}$ & 0.36 & 0.07 & 0.07 \\
\hline $\mathrm{Fe}_{2} \mathrm{O}_{3}$ & 0.26 & 0.05 & 0.05 \\
\hline $\mathrm{Gd}_{2} \mathrm{O}_{3}$ & 0.36 & 0.07 & 0.07 \\
\hline $\mathrm{K}_{2} \mathrm{O}$ & 6.29 & 1.15 & 1.20 \\
\hline $\mathrm{Li}_{2} \mathrm{O}$ & - & 7.0 & 8.00 \\
\hline $\mathrm{MoO}_{3}$ & 0.05 & 0.01 & 0.01 \\
\hline $\mathrm{Na}_{2} \mathrm{O}$ & - & 17.0 & 16.00 \\
\hline $\mathrm{P}_{2} \mathrm{O}_{5}$ & 2.93 & 0.54 & 0.56 \\
\hline $\mathrm{PbO}$ & 0.01 & - & - \\
\hline $\mathrm{SiO}_{2}$ & 0.38 & 52.74 & 52.08 \\
\hline $\mathrm{SrO}$ & 0.08 & 0.01 & 0.02 \\
\hline $\mathrm{CeO}_{2}$ & 0.33 & 0.06 & 0.06 \\
\hline $\mathrm{ZrO}_{2}$ & 79.09 & 14.47 & 15.03 \\
\hline Frit & - & $\# 1(B L-4)$ & $\# 2$ (BL-5) \\
\hline Loading & - & 18.3 & 19.0 \\
\hline
\end{tabular}




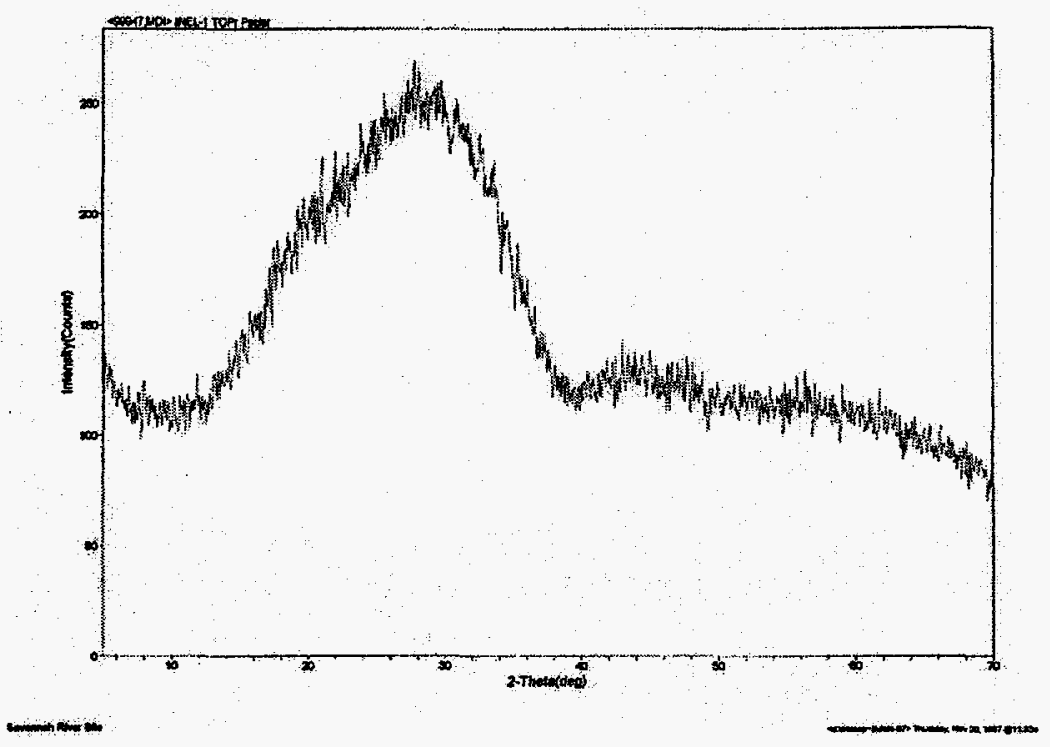

(a) Pour Patty

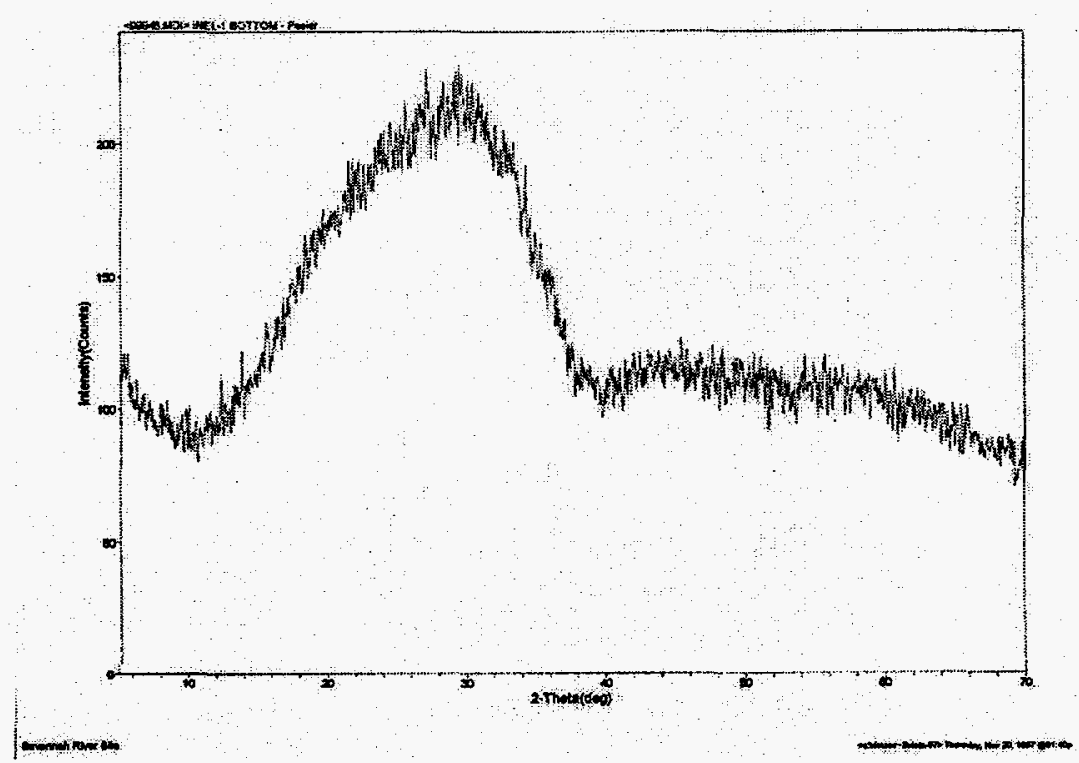

(b) Residual Crucible Glass

Figure 1. XRD Results of the "As-Fabricated" BL-4 Glass. 


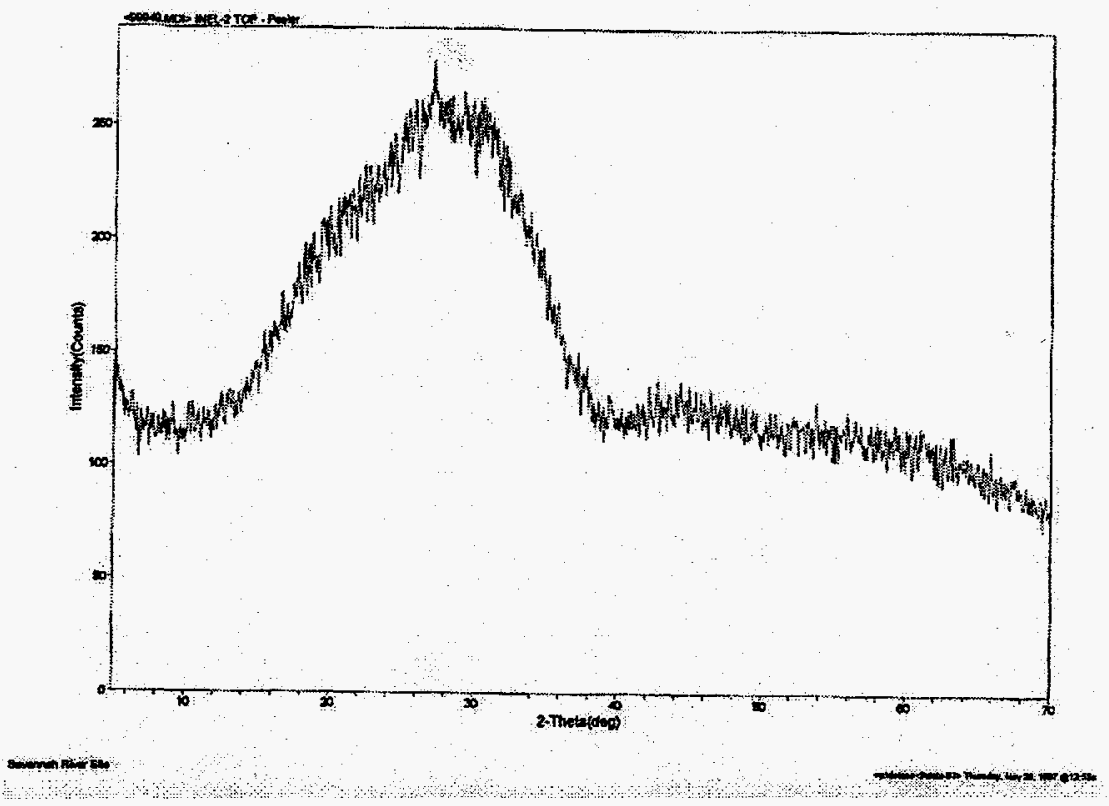

(a) Pour Patty

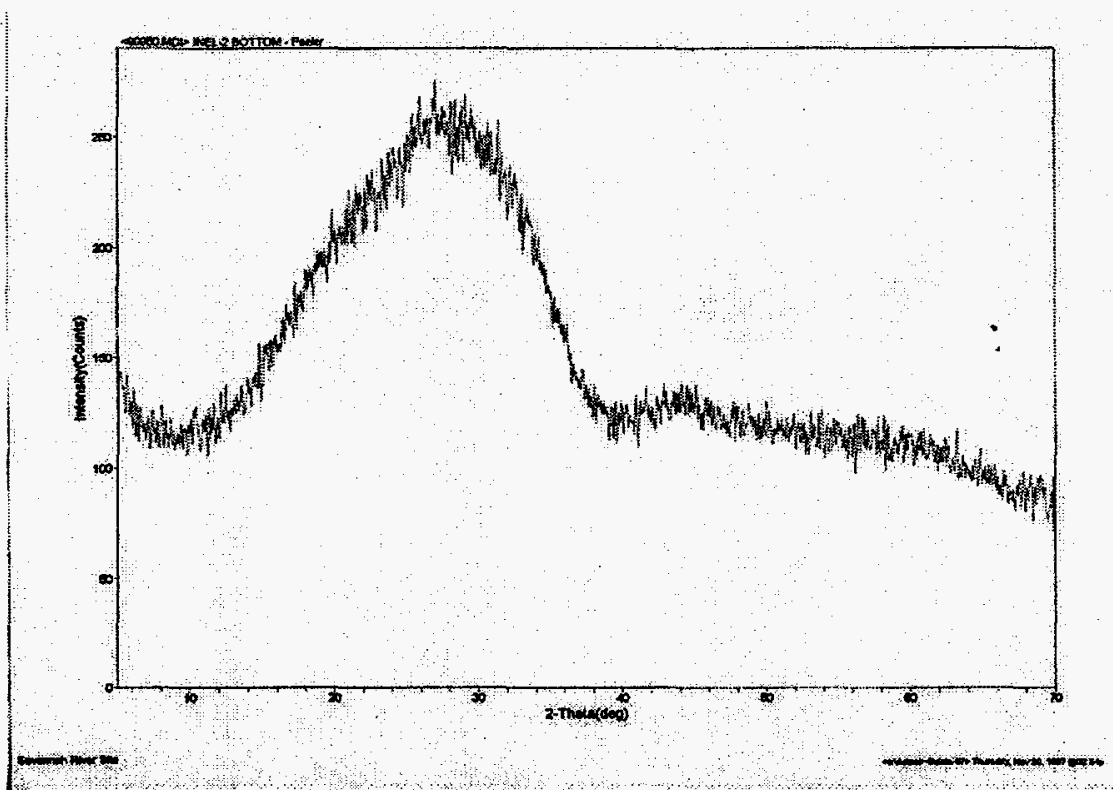

(b) Residual Crucible Glass

Figure 2. XRD Results of the "As-Fabricated" BL-5 Glass. 


\subsubsection{Durability}

Chemical durability of BL-4 and BL-5 was measured by the Product Consistency Test (PCT). Table X summarizes the final solution $\mathrm{pH}$ and the normalized release of $\mathrm{B}, \mathrm{Na}$, and $\mathrm{Li}$ for these two glasses. The normalized releases for the EA glass are also provided for comparison. All normalized releases from BL-4 and BL-5 are relatively high with only $\mathrm{B}$ and $\mathrm{Na}$ values being slightly lower than the EA glass. One explanation for the relatively low durability could be the high alkali content of the frits with only a limited amount of $\mathrm{Al}_{2} \mathrm{O}_{3}$ present from the waste (no $\mathrm{Al}_{2} \mathrm{O}_{3}$ additions from the frit)

Table X. PCT Results of BL-4 and BL-5.

\begin{tabular}{c|c|ccc}
\cline { 3 - 5 } & \multicolumn{3}{c}{ Normalized Release $(\mathrm{g} / \mathrm{L})$} \\
\hline Glass & $\mathrm{pH}$ (final) & $\mathrm{B}$ & $\mathrm{Na}$ & $\mathrm{Li}$ \\
\hline BL-4 & 11.91 & 14.59 & 11.19 & 11.90 \\
BL-5 & 11.99 & 12.52 & 9.51 & 9.94 \\
EA & 11.85 & 16.695 & 13.346 & 9.565 \\
\hline
\end{tabular}

\subsubsection{Summary}

After evaluation of approximately 8 glasses, BL-4 and BL-5 glass met all the primary processing constraints $\left(\mathrm{T}_{\mathrm{L}}\right.$ and pourability at $\left.1150^{\circ} \mathrm{C}\right)$ with relatively high loadings. However, the performance of the final product as measured by the PCT were inadequate eliminating these two glasses from further consideration as potential candidates for melter processing. Although durability was the limiting factor in these glasses the results were very encouraging.

Development of BL-6 and BL-7 focused on the effects of the boron and alumina additions as well as alkali $\left(\mathrm{Na}_{2} \mathrm{O}\right.$ and $\left.\mathrm{Li}_{2} \mathrm{O}\right)$ distribution on the targeted constraints. The primary objective was to evaluate the effect on $\mathrm{T}_{\mathrm{L}}$ and durability (either by reducing alkali concentration and/or addition of $\mathrm{Al}_{2} \mathrm{O}_{3}$ ). 


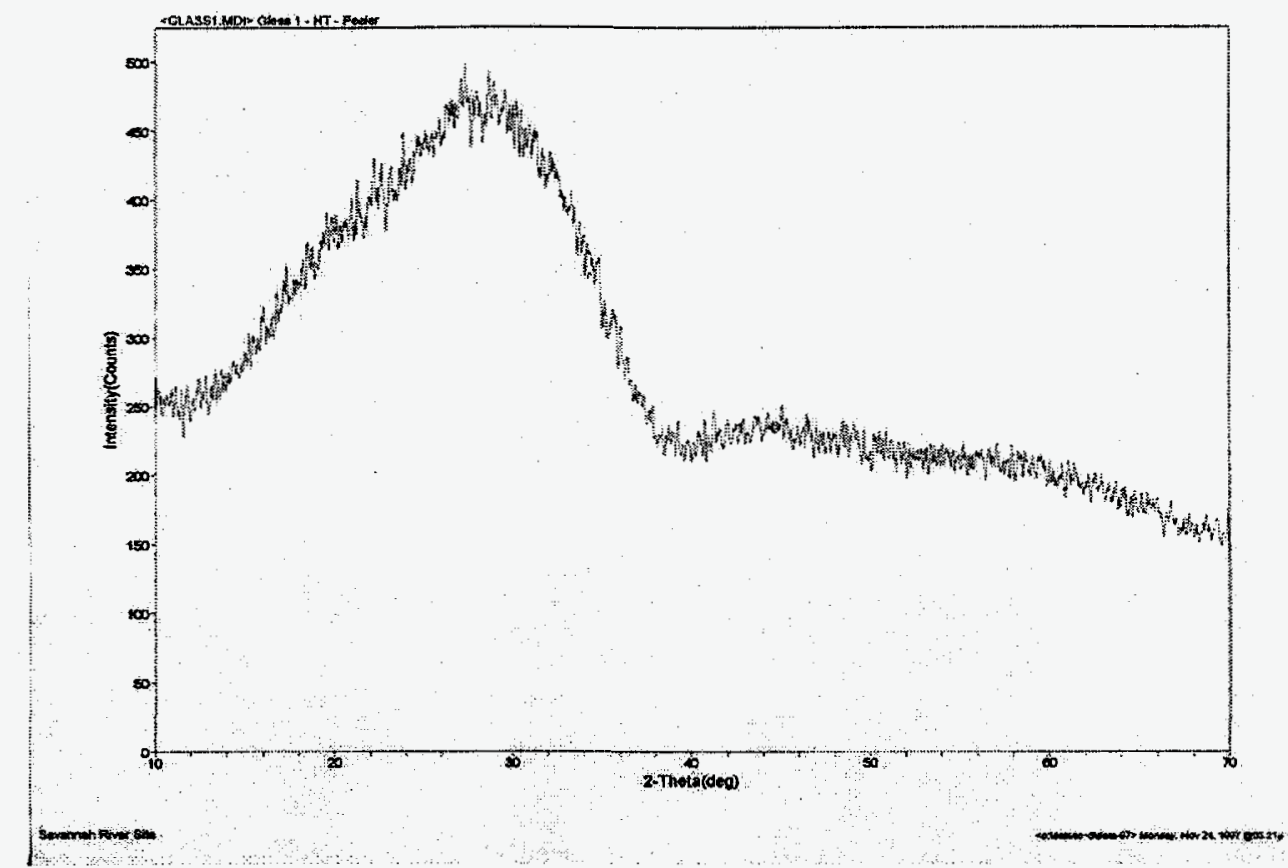

Figure 3. XRD Results of BL-4 Heat Treated at $1050^{\circ} \mathrm{C}$ for 24 Hours.

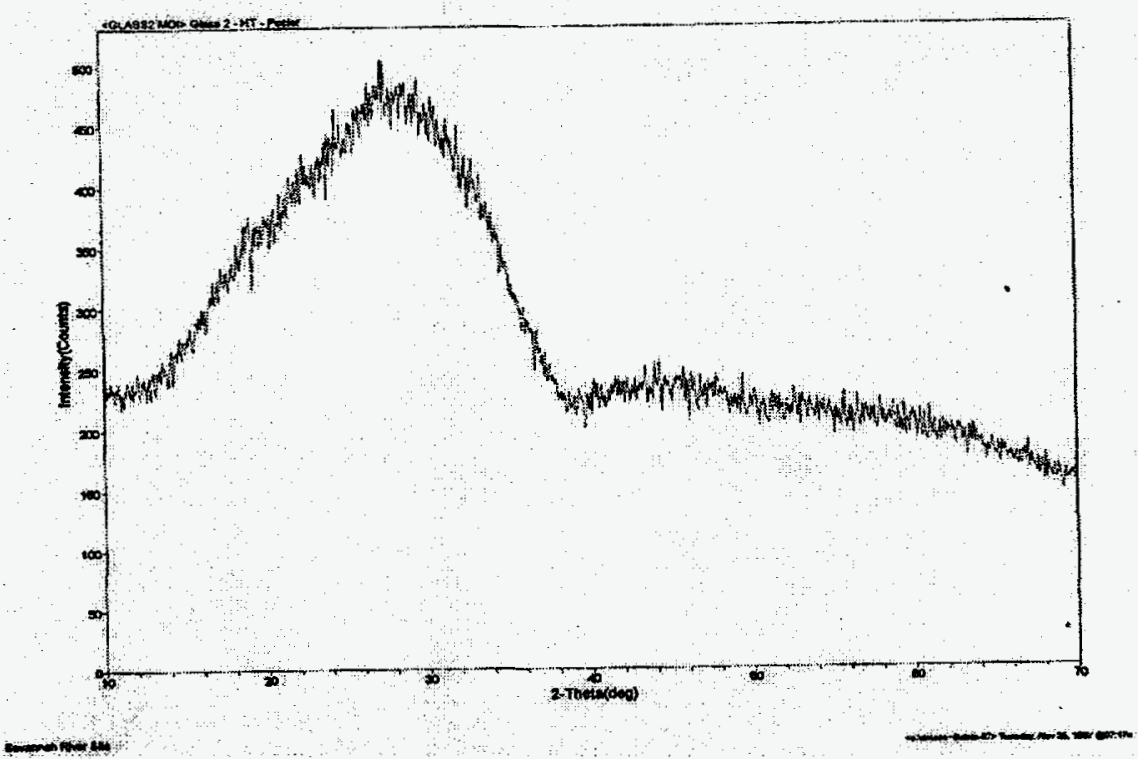

Figure 4. XRD Results of BL-5 Heat Treated at $1050^{\circ} \mathrm{C}$ for 24 Hours. 


\subsection{BL-6 Frit}

BL-6 was developed by reducing the $\mathrm{Na}_{2} \mathrm{O}$ content from $16 \mathrm{wt} \%$ in glass to $12.5 \mathrm{wt} \%$ relative to $\mathrm{BL}-5$. Table XI summarizes the BL-6 frit and $19.0 \mathrm{wt} \%$ loaded target glass compositions.

\subsubsection{Homogeneity}

Visual observations indicated complete dissolution of all waste oxide components (i.e., no detection of undissolved $\mathrm{ZrO}_{2}$ at $19.0 \mathrm{wt} \%$ loading) upon initial fabrication of $\mathrm{BL}-6$ at $1150^{\circ} \mathrm{C}$. Visual observations of homogeneity were confirmed by optical microscopy.

Table XI. BL-6 Frit and 19.0 wt\% "All Blend" Target Glass Compositions. (in wt \%)

\begin{tabular}{cccc}
\hline \hline Oxide & "All Blend" & BL-6 Frit & BL-6 Glass \\
\hline $\mathrm{Al}_{2} \mathrm{O}_{3}$ & 8.9 & 0.00 & 1.69 \\
$\mathrm{~B}_{2} \mathrm{O}_{3}$ & - & 6.17 & 5.00 \\
$\mathrm{BaO}$ & 0.02 & - & 0.00 \\
$\mathrm{CaO}$ & 0.45 & - & 0.09 \\
$\mathrm{Cs} \mathrm{O}_{2}$ & 0.5 & - & 0.09 \\
$\mathrm{CuO}$ & 0.36 & - & 0.07 \\
$\mathrm{Fe}_{2} \mathrm{O}_{3}$ & 0.26 & - & 0.05 \\
$\mathrm{Gd}_{2} \mathrm{O}_{3}$ & 0.36 & - & 0.07 \\
$\mathrm{~K}_{2} \mathrm{O}$ & 6.29 & - & 1.20 \\
$\mathrm{Li}_{2} \mathrm{O}$ & - & 9.88 & 8.00 \\
$\mathrm{MoO}_{3}$ & 0.05 & - & 0.01 \\
$\mathrm{Na}_{2} \mathrm{O}$ & - & 15.47 & 12.53 \\
$\mathrm{P}_{2} \mathrm{O}_{5}$ & 2.93 & - & 0.56 \\
$\mathrm{PbO}$ & 0.01 & - & 0.00 \\
$\mathrm{SiO}_{2}$ & 0.38 & 68.48 & 55.54 \\
$\mathrm{SrO} \mathrm{O} O$ & 0.08 & - & 0.01 \\
$\mathrm{CeO}_{2}$ & 0.33 & - & 0.06 \\
$\mathrm{ZrO}_{2}$ & 79.09 & - & 15.03 \\
$\mathrm{Lading}$ & - & - & 19.0 \\
\hline
\end{tabular}

\subsubsection{Viscosity}

Based on visual observations and comparison with other high-level waste glasses processed at similar temperatures, the viscosity of BL-6 should be within the processing constraints of $20-100$ Poise at $1150^{\circ} \mathrm{C}$. A "formal" high temperature viscosity curve was not performed to confirm these semiquantitative, visual observations. 


\subsubsection{Liquidus Temperature Constraint}

The 24 hour isothermal liquidus temperature measurement indicates that the $1050^{\circ} \mathrm{C}$ constraint was met $\left(\mathrm{T}_{\mathrm{L}}\right.$ $<1050^{\circ} \mathrm{C}$ for BL-6). Based on the results of BL-6, it appears that a small reduction in the total alkali concentration $\left(\mathrm{B}_{2} \mathrm{O}_{3}\right.$ level remaining at $5 \mathrm{wt} \%$ in glass) produces a homogeneous glass that meets all processing constraints at a $19 \mathrm{wt} \%$ "All Blend" loading. Although the lower $\mathrm{Na}_{2} \mathrm{O}$ concentration (relative to $B L-4$ and $B L-5$ ) did not negatively impact $T_{L}$, its effect on product performance (e.g., durability) was not evaluated.

\subsection{BL-7 Frit}

To evaluate the effects of higher $\mathrm{B}_{2} \mathrm{O}_{3}$ concentrations on the primary processing parameters, $\mathrm{BL}-7$ was formulated. The increase in $\mathrm{B}_{2} \mathrm{O}_{3}$ content was countered by a decrease in the total alkali $\left(\mathrm{Na}_{2} \mathrm{O}\right.$ and $\left.\mathrm{Li}_{2} \mathrm{O}\right)$ concentration relative to BL-6. Table XII shows the BL-7 frit and targeted 19.0 wt\% "All Blend" glass compositions. $\mathrm{B}_{2} \mathrm{O}_{3}$ content was increased to $10 \mathrm{wt} \%$ in glass up from $5 \mathrm{wt} \%$ in the $\mathrm{BL}-6$ glass composition. The total alkali concentration in BL-7 was reduced to approximately $17 \mathrm{wt} \%$ in glass down from $20 \mathrm{wt} \%$ in BL-6.

Table XII. BL-7 Frit and 19.0 wt\% "All Blend" Target Glass Compositions.

(in wt \%)

\begin{tabular}{cccc}
\hline Oxide & “All Blend" & BL-7 Frit & BL-7 Glass \\
\hline $\mathrm{Al}_{2} \mathrm{O}_{3}$ & 8.9 & - & 1.69 \\
$\mathrm{~B}_{2} \mathrm{O}_{3}$ & - & 12.35 & 10.00 \\
$\mathrm{BaO}$ & 0.02 & - & 0.00 \\
$\mathrm{CaO}$ & 0.45 & - & 0.09 \\
$\mathrm{Cs} \mathrm{O}_{2}$ & 0.5 & - & 0.09 \\
$\mathrm{CuO}$ & 0.36 & - & 0.07 \\
$\mathrm{Fe}_{2} \mathrm{O}_{3}$ & 0.26 & - & 0.05 \\
$\mathrm{Gd}_{2} \mathrm{O}_{3}$ & 0.36 & - & 0.07 \\
$\mathrm{~K}_{2} \mathrm{O}$ & 6.29 & - & 1.20 \\
$\mathrm{Li}_{2} \mathrm{O}$ & - & 8.64 & 7.00 \\
$\mathrm{MoO}_{3}$ & 0.05 & - & 0.01 \\
$\mathrm{Na}_{2} \mathrm{O}$ & - & 13.46 & 10.90 \\
$\mathrm{P}_{2} \mathrm{O}_{5}$ & 2.93 & - & 0.56 \\
$\mathrm{PbO}$ & 0.01 & - & 0.00 \\
$\mathrm{SiO}_{2}$ & 0.38 & 65.56 & 53.17 \\
$\mathrm{SrO}_{\mathrm{CeO}}$ & 0.08 & - & 0.01 \\
$\mathrm{ZrO}_{2}$ & 0.33 & - & 0.06 \\
$\mathrm{Loading}_{2}$ & 79.09 & - & 15.03 \\
\hline & - & - & 19.0 \\
\hline
\end{tabular}




\subsubsection{Homogeneity}

Initial fabrication of BL-7 at $1150^{\circ} \mathrm{C}$ resulted in homogeneous glass. Visual observations indicated complete dissolution of all waste oxide components (i.e., no detection of undissolved $\mathrm{ZrO}_{2}$ observed). Visual observations were confirmed by optical microscopy.

\subsubsection{Viscosity}

Based on visual observations and comparison with other high-level waste glasses processed at similar temperatures, the viscosity of BL-7 should be within the processing constraints of $20-100$ Poise at $1150^{\circ} \mathrm{C}$. A "formal" high temperature viscosity curve was not performed to confirm these semiquantitative, visual observations.

\subsubsection{Liquidus Temperature Constraint}

The 24 hour isothermal liquidus temperature measurement indicates that the $1050^{\circ} \mathrm{C}$ constraint was met $\left(\mathrm{T}_{\mathrm{L}}\right.$ $<1050^{\circ} \mathrm{C}$ for BL-7). An additional heat treatment at $1000^{\circ} \mathrm{C}$ also showed no signs of crystallization indicating that $T_{L}<1000^{\circ} \mathrm{C}$. Based on the results of $\mathrm{BL}-7$, it appears that additions of $\mathrm{B}_{2} \mathrm{O}_{3}$ (up to $10 \mathrm{wt} \%$ ) accompanied by a relatively large reduction in total alkali content produces a homogeneous glass that meets all processing constraints at $19 \mathrm{wt} \%$ "All Blend" loading. The reduction in total alkali content for BL-7 was $2.63 \mathrm{wt} \%$ relative to the BL-6 glass and $3.25 \mathrm{wt} \%$ relative to the BL-6 frit (see Table XIII). It should be noted that product performance (e.g., durability) of BL-7 was not evaluated.

Table XIII. Comparison of Total Alkali Distribution for BL-4, BL-5, BL-6, and BL-7.

\begin{tabular}{ccc}
\hline Glass & Na wt\% & Li wt\% \\
\hline BL-4 & 17.0 & 7.0 \\
BL-5 & 16.0 & 8.0 \\
BL-6 & 12.5 & 8.0 \\
BL-7 & 10.9 & 7.0 \\
\hline
\end{tabular}




\subsection{Primary Candidates for Initial INEEL Melter Runs (BL-8 and BL-9)}

Based on the compositional changes and the related effects on the targeted constraints of glasses BL-1 through BL-7, two additional glasses were fabricated (BL-8 and BL-9). Previous testing had indicated that durability was a limiting factor (see Section 5.2.1.4). $\mathrm{Al}_{2} \mathrm{O}_{3}$ is known to increase durability in borosilicate glasses although with a non-linear effect. That is, initial additions of $\mathrm{Al}_{2} \mathrm{O}_{3}$ can have a dramatic impact on improving durability but increasing its concentration above approximately $3-5 \mathrm{wt} \%$ in glass is usually not warranted. Figure 5 shows the effect of $\mathrm{Al}_{2} \mathrm{O}_{3}$ additions on the PCT of two different simulated $\mathrm{HLW}$ glasses [14]. This figure clearly illustrates the dramatic increase in durability obtained by the addition of $\mathrm{Al}_{2} \mathrm{O}_{3}$ until a concentration of roughly $5 \mathrm{wt} \%$ in these specific glasses. To assess the effect on INEEL "All Blend" glasses, a series of glasses were defined in which incremental additions of $\mathrm{Al}_{2} \mathrm{O}_{3}$ would be made to the BL-6 glass composition until either the $\mathrm{Al}_{2} \mathrm{O}_{3}$ concentration was 4 wt\% (in glass) or the $1050^{\circ} \mathrm{CT}_{\mathrm{L}}$ constraint was exceeded. All glasses would target a 19.0 wt\% "All Blend" loading. 


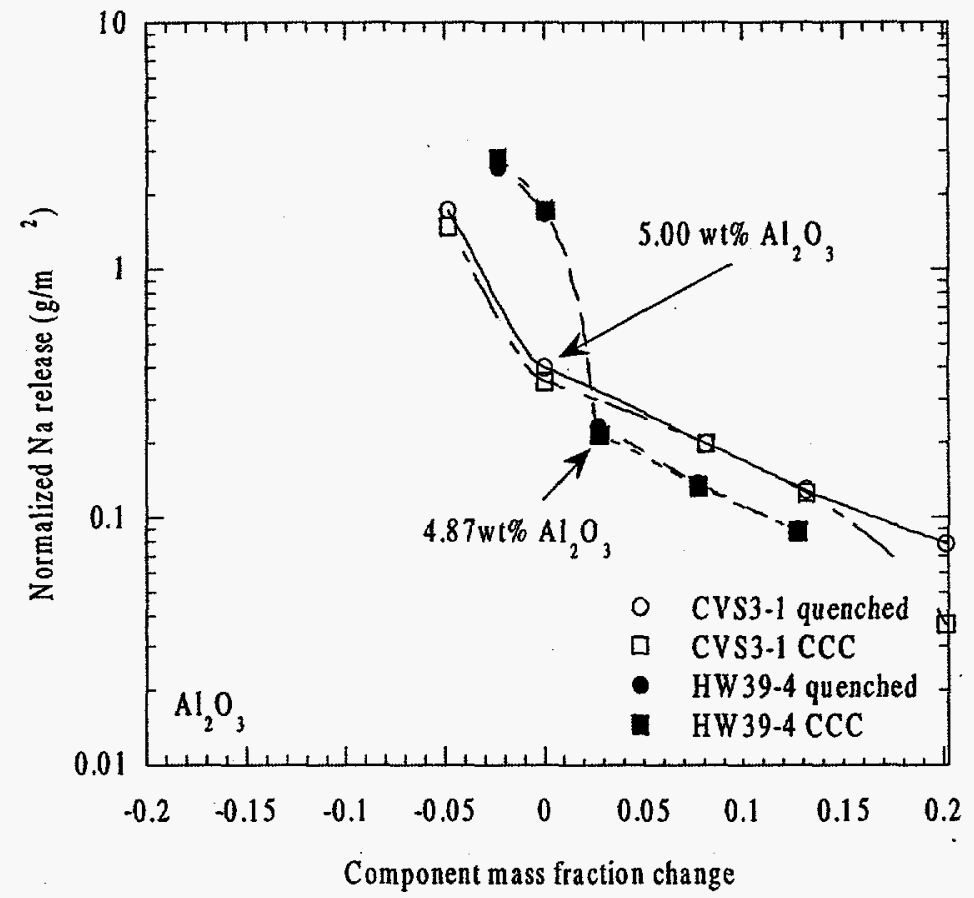

Figure 5. Normalized Sodium Release by PCT as a Function of $\mathrm{Al}_{2} \mathrm{O}_{3}$ Addition (or Subtraction) from two Glasses (CVS3-1 and HW39-4).

Note: Round symbols represent quenched glass while squares represent glasses cooled according to a simulated DWPF canister centerline cooling schedule. [Taken from reference 14] 


\subsubsection{BL-8 Frit}

The initial glass evaluated was $\mathrm{BL}-8$ which incorporated $4 \mathrm{wt} \% \mathrm{Al}_{2} \mathrm{O}_{3}$ (see Table XIV).

Table XIV. BL-8 Frit and 19.0 wt\% "All Blend" Targeted Glass Compositions. (in wt \%)

\begin{tabular}{cccc}
\hline Oxide & "All Blend" & BL-8 Frit & BL-8 Glass \\
\hline $\mathrm{Al}_{2} \mathrm{O}_{3}$ & 8.9 & 2.85 & 4.00 \\
$\mathrm{~B}_{2} \mathrm{O}_{3}$ & - & 6.17 & 5.00 \\
$\mathrm{BaO}$ & 0.02 & - & 0.00 \\
$\mathrm{CaO}$ & 0.45 & - & 0.09 \\
$\mathrm{Cs} 2 \mathrm{O}$ & 0.5 & - & 0.09 \\
$\mathrm{CuO}$ & 0.36 & - & 0.07 \\
$\mathrm{Fe}_{2} \mathrm{O}_{3}$ & 0.26 & - & 0.05 \\
$\mathrm{Gd}_{2} \mathrm{O}_{3}$ & 0.36 & - & 0.07 \\
$\mathrm{~K}_{2} \mathrm{O}$ & 6.29 & - & 1.20 \\
$\mathrm{Li}_{2} \mathrm{O}$ & - & 9.88 & 8.00 \\
$\mathrm{MoO}_{3}$ & 0.05 & - & 0.01 \\
$\mathrm{Na}_{2} \mathrm{O}$ & - & 15.74 & 12.75 \\
$\mathrm{P}_{2} \mathrm{O}_{5}$ & 2.93 & - & 0.56 \\
$\mathrm{PbO}$ & 0.01 & - & 0.00 \\
$\mathrm{SiO}_{2}$ & 0.38 & 65.36 & 53.02 \\
$\mathrm{SrO}_{\mathrm{CeO}_{2}}$ & 0.08 & - & 0.01 \\
$\mathrm{ZrO}_{2}$ & 0.33 & - & 0.06 \\
$\mathrm{Lading}$ & 79.09 & - & 15.03 \\
\hline
\end{tabular}

\subsubsection{Homogeneity}

Visual observations indicated complete dissolution of all waste oxide components (i.e., no detection of undissolved $\mathrm{ZrO}_{2}$ observed) upon initial fabrication of $\mathrm{BL}-8$ at $1150^{\circ} \mathrm{C}$. Visual observations were confirmed by optical microscopy and XRD analysis.

A sample from both the pour patty and the residual crucible glass were submitted to XRD to confirm visual observations. Figure 6 shows the XRD patterns obtained from the pour patty and residual crucible glass of BL-8. The presence of an amorphous hump (or absence of well defined peaks) indicates that the sample is homogeneous and contains no undissolved raw materials at the detection limit of the XRD unit (approximately $0.3-0.5 \mathrm{wt} \%$ based on the XRD run parameters). 


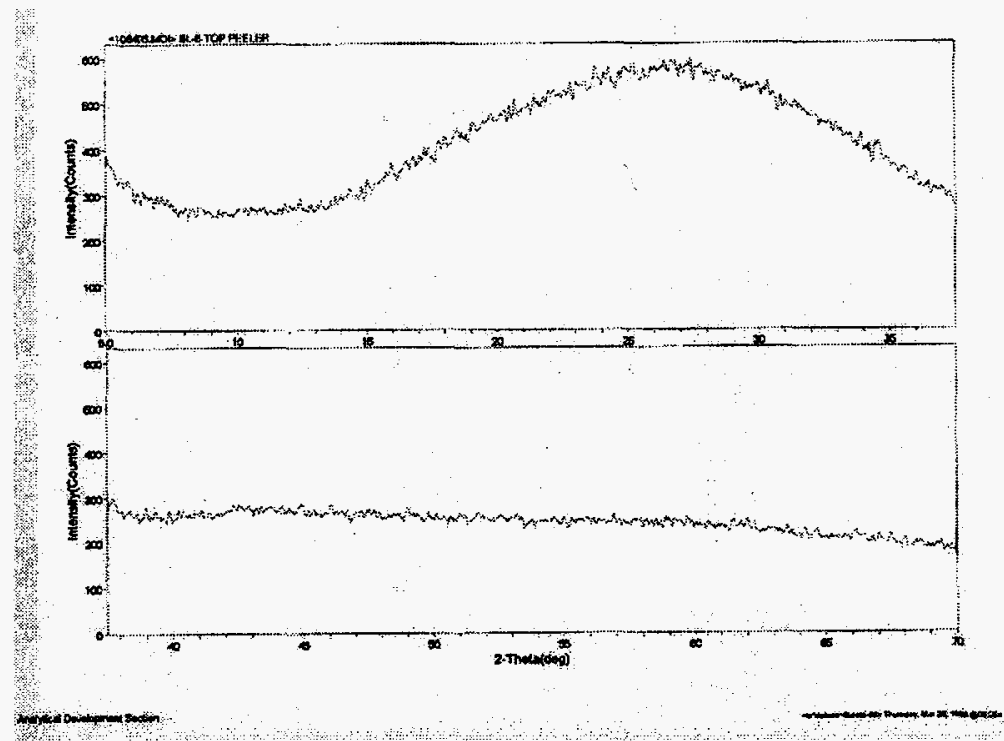

(a) Pour Patty

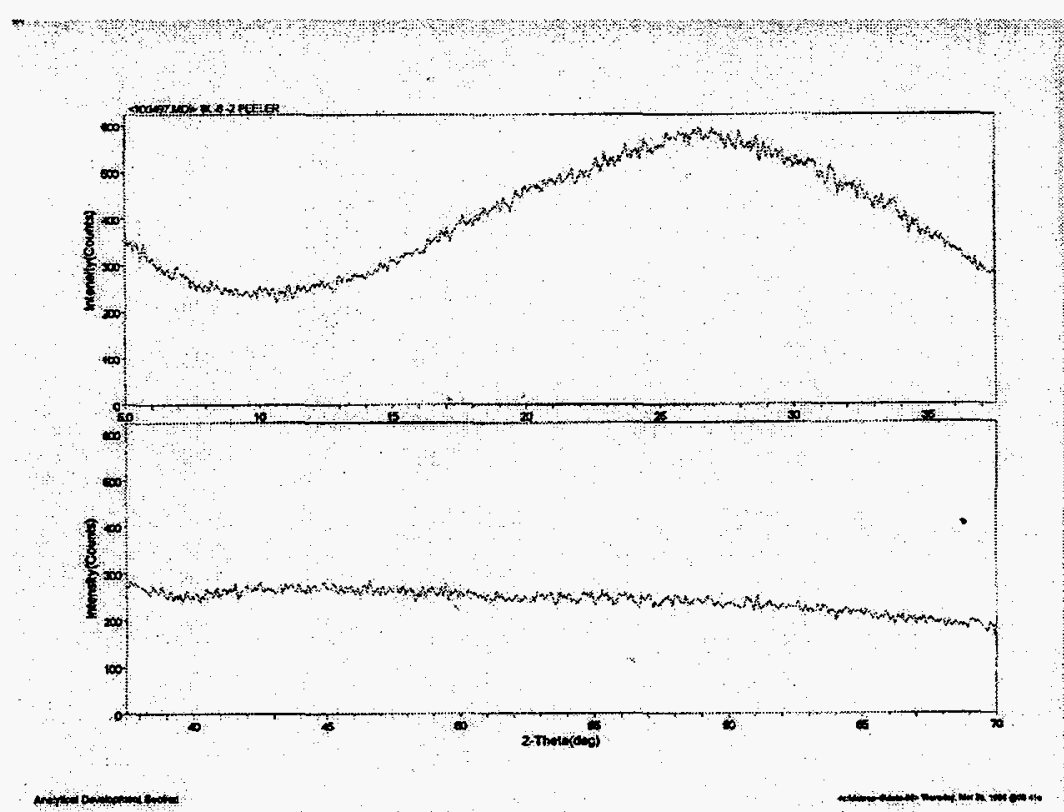

(b) Residual Crucible Glass

Figure 6. XRD Results of the "As Fabricated" BL-8 Glass. 


\subsubsection{Viscosity}

Based on visual observations and comparison with other high-level waste glasses processed at similar temperatures, the viscosity of BL-8 should be within the processing constraints of $20-100$ Poise at $1150^{\circ} \mathrm{C}$. A "formal" high temperature viscosity curve was performed to confirm visual observations (see Figure 7). At $1150^{\circ} \mathrm{C}$, the measured viscosity' was 83 Poise.

\subsubsection{Liquidus Temperature Constraint}

Visual observations after a 24 hour isothermal hold at $1050^{\circ} \mathrm{C}$ resulted in a visually homogeneous glass indicating that the $T_{L}$ constraint was met $\left(T_{L}<1050^{\circ} \mathrm{C}\right.$ for BL-8). Figures 8 and 9 respectively show the $\mathrm{XRD}$ pattern and a SEM micrograph of the BL-8 glass heat treated at $1050^{\circ} \mathrm{C}$ for 24 hours. Based on the presence of the amorphous hump (or lack of well defined peaks) in Figure 8, XRD confirmed visual observations that $T_{\mathrm{L}}$ is $<1050^{\circ} \mathrm{C}$. Both visual and XRD results were confirmed by the lack of any crystallization in the SEM micrograph (see Figure 9). An additional isothermal test was performed at $1025^{\circ} \mathrm{C}$ for 24 hours. The results of this test indicated that $T_{L}$ for $B L-8$ was below $1025^{\circ} \mathrm{C}$ (i.e., crystals not observed by either visual observation and/or optical microscopy).

\subsubsection{Durability}

Chemical durability of BL-8 was measured by the Product Consistency Test (PCT). Table XV summarizes the final solution $\mathrm{pH}$ and the normalized release of $\mathrm{B}, \mathrm{Na}$, and $\mathrm{Li}$ for this glass performed by both PNNL and SRTC. The normalized releases for the EA glass are also provided for comparison.

Table XV. PCT Results for BL-8.

\begin{tabular}{c|c|ccc}
\cline { 3 - 5 } \multicolumn{2}{c}{} & \multicolumn{3}{c}{ Normalized Release (g/L) } \\
\hline Glass & pH (final) & B & Na & Li \\
\hline BL-8 (Lab \#1) & 11.62 & .520 & 1.116 & 0.990 \\
BL-8 (Lab \#2) & 11.78 & .460 & 1.210 & 1.020 \\
EA & 11.85 & 16.695 & 13.346 & 9.565 \\
\hline
\end{tabular}

Based on the 7-day PCT results, all elemental releases are an order of magnitude below those of the EA glass. These release values are typical of HAW glasses fabricated for DWPF and Hanford. Comparing the release values of $\mathrm{BL}-8$ to those of $\mathrm{BL}-4$ and $\mathrm{BL}-5$ (see Table $\mathrm{X}$ ), the addition of $\mathrm{Al}_{2} \mathrm{O}_{3}$ appears to have a dramatic effect on the durability of these glasses.

\subsubsection{Summary}

The results of BL- 8 indicate that this glass meets all targeted processing and product performance constraints as defined in Table II. The addition of $\mathrm{Al}_{2} \mathrm{O}_{3}$ appears to have increased the durability to an "acceptable" level while maintaining other processing constraints. "All Blend" waste loadings of up to $19.0 \mathrm{wt} \%$ (translating into approximately $15.0 \mathrm{wt} \% \mathrm{ZrO}_{2}$ ) are achievable in a borosilicate system. In 
addition, increased "All Blend" waste loadings appear to be likely since measured property values are well within targeted constraints.

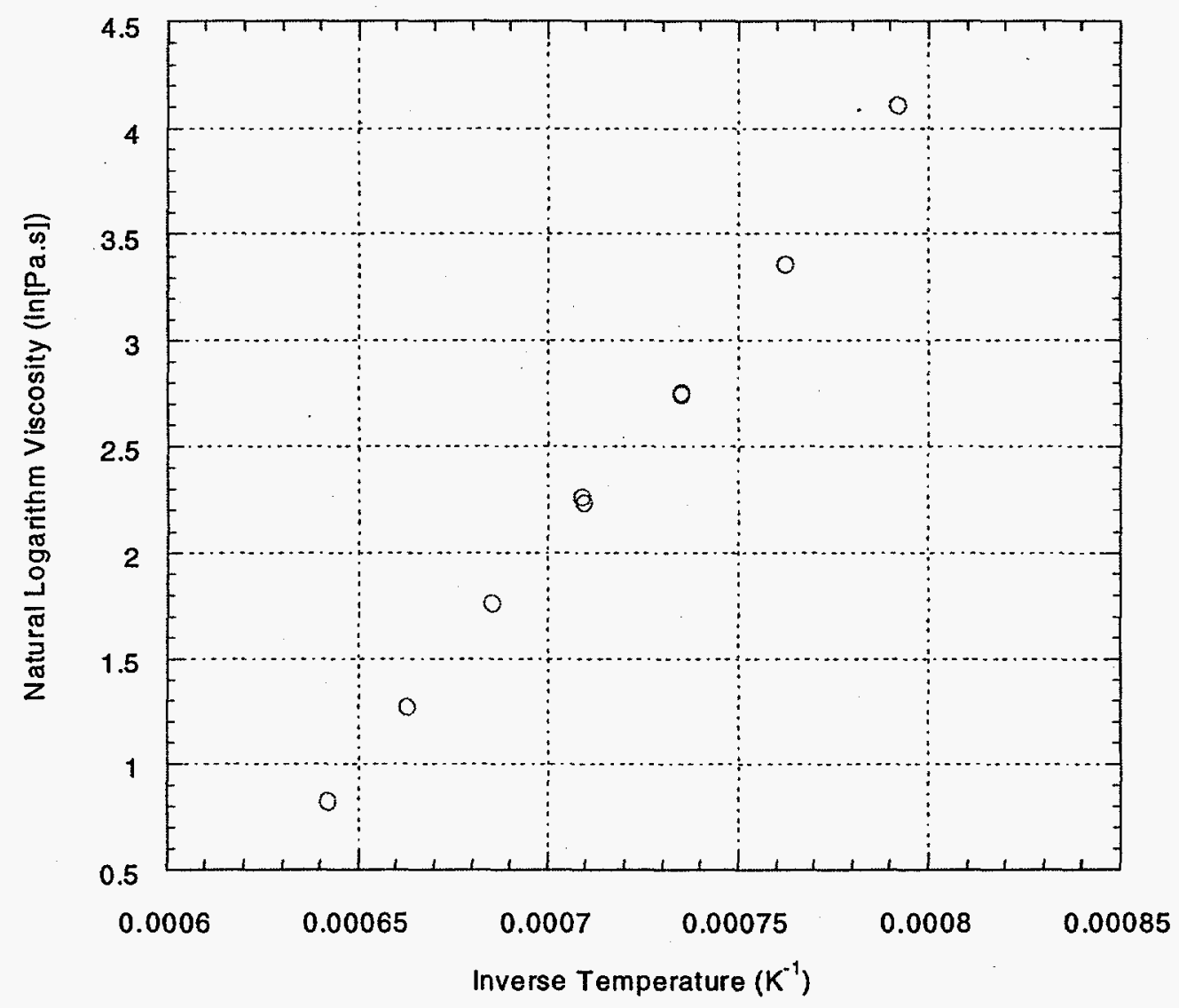

( $\ln \eta=A+B / T_{0}$ where $A=-12.955$ and $B=21,446.2 \mathrm{~K}$ )

Figure 7. High Temperature Viscosity Curve for BL-8. 


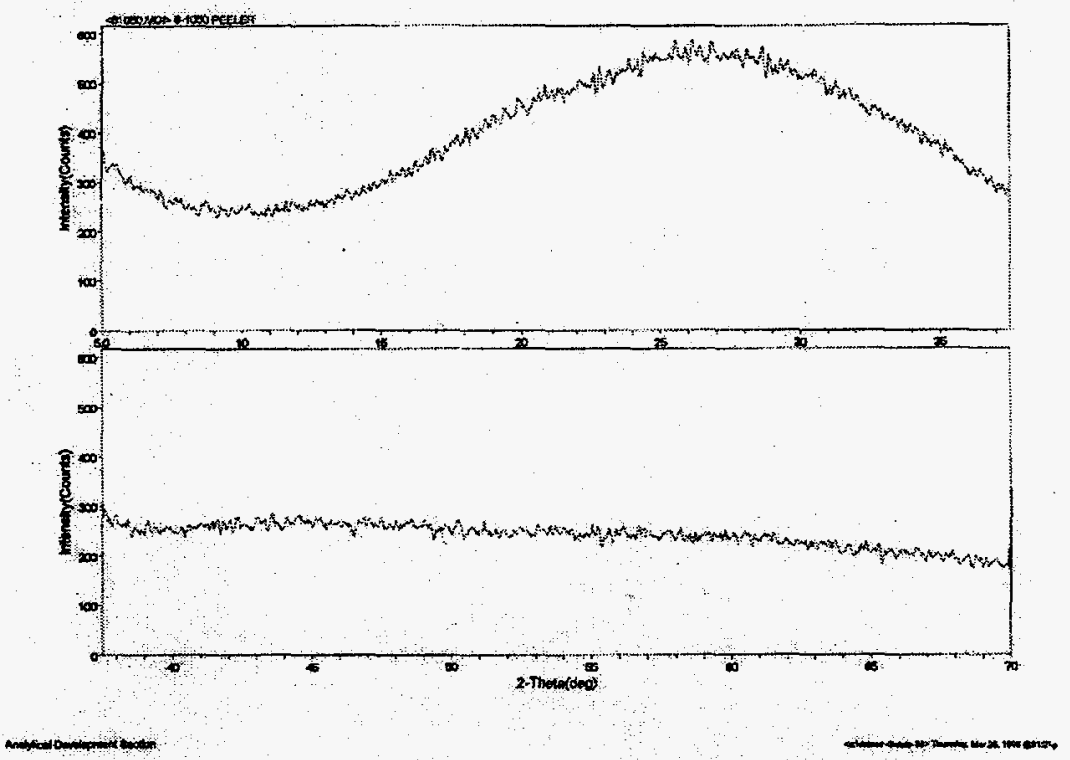

Figure 8. XRD Results of BL-8 Heat Treated at $1050^{\circ} \mathrm{C}$ for 24 Hours.

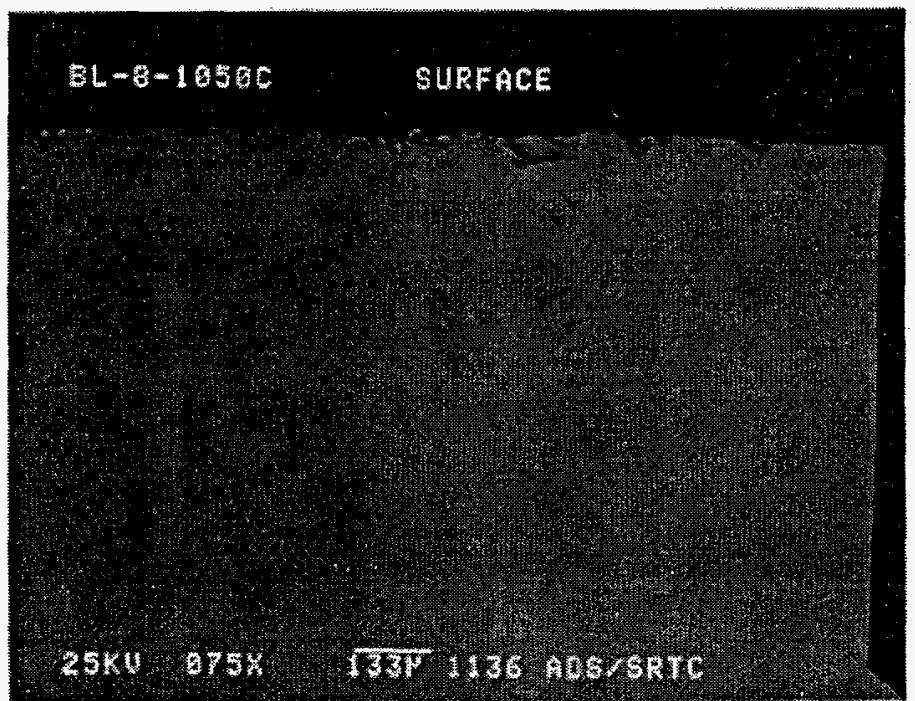

Figure 9. SEM Micrograph of BL-8 Heat Treated at $1050^{\circ} \mathrm{C}$ for 24 Hours. 


\subsubsection{BL.9 Frit}

A second glass was developed in parallel with BL-8. Due to previous observations that increased $\mathrm{B}_{2} \mathrm{O}_{3}$ contents with reduced alkali concentrations did not have negative impacts on the processing constraints, BL-9 was formulated. Table XVI summarizes the frit and targeted glass (19.0 wt\% loading) compositions. The $\mathrm{B}_{2} \mathrm{O}_{3}$ concentration in this glass was $15 \mathrm{wt} \%$ with a reduction of total alkali to approximately $15 \mathrm{wt} \%$ relative to $\mathrm{BL}-7$. There were no $\mathrm{Al}_{2} \mathrm{O}_{3}$ additions from the frit.

Table XVI. BL-9 Frit and 19.0 wt\% "All Blend" Targeted Glass Compositions. (in wt \%)

\begin{tabular}{cccc}
\hline \hline Oxide & "All Blend" & BL-9 Frit & BL-9 Glass \\
\hline $\mathrm{Al}_{2} \mathrm{O}_{3}$ & 8.9 & - & 1.69 \\
$\mathrm{~B}_{2} \mathrm{O}_{3}$ & - & 18.52 & 15.00 \\
$\mathrm{BaO}$ & 0.02 & - & 0.00 \\
$\mathrm{CaO}$ & 0.45 & - & 0.09 \\
$\mathrm{Cs} \mathrm{O}_{2}$ & 0.5 & - & 0.09 \\
$\mathrm{CuO}$ & 0.36 & - & 0.07 \\
$\mathrm{Fe}_{2} \mathrm{O}_{3}$ & 0.26 & - & 0.05 \\
$\mathrm{Gd}_{2} \mathrm{O}_{3}$ & 0.36 & - & 0.07 \\
$\mathrm{~K}_{2} \mathrm{O}$ & 6.29 & - & 1.20 \\
$\mathrm{Li}_{2} \mathrm{O}$ & - & 7.41 & 6.00 \\
$\mathrm{MoO}_{3}$ & 0.05 & - & 0.01 \\
$\mathrm{Na}_{2} \mathrm{O}$ & - & 11.44 & 9.27 \\
$\mathrm{P}_{2} \mathrm{O}_{5}$ & 2.93 & - & 0.56 \\
$\mathrm{PbO}$ & 0.01 & - & 0.00 \\
$\mathrm{SiO}_{2}$ & 0.38 & 62.63 & 50.80 \\
$\mathrm{SrO}_{\mathrm{CeO}_{2}}$ & 0.08 & - & 0.01 \\
$\mathrm{ZrO}_{2}$ & 0.33 & - & 0.06 \\
$\mathrm{LOading}$ & 79.09 & - & 15.03 \\
\hline
\end{tabular}

\subsubsection{Homogeneity}

Visual observations indicated complete dissolution of all waste oxide components (i.e., no detection of undissolved $\mathrm{ZrO}_{2}$ observed) upon initial fabrication of $\mathrm{BL}-9$ at $1150^{\circ} \mathrm{C}$. Visual observations were confirmed by optical microscopy and XRD analysis. A sample from both the pour patty and the residual crucible glass were submitted to XRD to confirm visual observations. Figure 10 shows the XRD patterns obtained from the pour patty and residual crucible glass of BL-9. The presence of an amorphous hump (or absence of well defined peaks) indicates that the sample is homogeneous and contains no undissolved raw materials at the detection limit of the XRD unit (approximately $0.3-0.5 \mathrm{wt} \%$ based on the XRD run parameters). 


\subsubsection{Viscosity}

Based on visual observations and comparison with other high-level waste glasses processed at similar temperatures, the viscosity of BL-9 should be within the processing constraints of $20-100$ Poise at $1150^{\circ} \mathrm{C}$. A "formal" high temperature viscosity curve was performed to confirm visual observations (see Figure 11). At $1150^{\circ} \mathrm{C}$, the measured viscosity was 59 Poise.

\subsubsection{Liquidus Temperature Constraint}

Visual observations after a 24 hour isothermal hold at $1050^{\circ} \mathrm{C}$ resulted in a visually homogeneous glass indicating that the $T_{L}$ constraint was met $\left(T_{L}<1050^{\circ} \mathrm{C}\right.$ for BL-9). Figures 12 and 13 respectively show the XRD pattern and a SEM micrograph of the BL-9 glass heat treated at $1050^{\circ} \mathrm{C}$ for 24 hours. Based on the presence of the amorphous hump (or lack of well defined peaks) in Figure 12, XRD confirmed visual observations that $T_{L}$ is $\angle 1050^{\circ} \mathrm{C}$. Both visual and XRD results were confirmed by the lack of any crystallization in the SEM micrograph (see Figure 13). An additional isothermal test was performed at $1025^{\circ} \mathrm{C}$ for 24 hours. The results of this test indicated that $T_{L}$ for $B L-9$ was between $1025^{\circ} \mathrm{C}$ and $1050^{\circ} \mathrm{C}$. Although observed after the $1025^{\circ} \mathrm{C}$ test, the crystals were extremely isolated (i.e., limited in number) and scattered throughout the glass matrix.

\subsubsection{Durability}

Chemical durability of BL-9 was measured by the Product Consistency Test (PCT). Table XVII summarizes the final solution $\mathrm{pH}$ and the normalized release of $\mathrm{B}, \mathrm{Na}$, and $\mathrm{Li}$ for this glass from both PNNL and SRTC. The normalized releases for the EA glass are also provided for comparison.

Table XVII. PCT Results for BL-9.

\begin{tabular}{c|c|ccc}
\cline { 3 - 5 } & \multicolumn{3}{c}{ Normalized Release (g/L) } \\
\hline Glass & $\mathrm{pH}$ (final) & B & $\mathrm{Na}$ & $\mathrm{Li}^{\circ}$ \\
\hline BL-9 (Lab \#1) & 10.14 & 1.756 & 0.918 & 1.602 \\
BL-9 (Lab \#2) & 10.37 & 1.810 & 0.970 & 1.760 \\
EA & 11.85 & 16.695 & 13.346 & 9.565 \\
\hline
\end{tabular}

Based on the 7-day PCT results, all elemental releases are well below those of the EA glass. These release values are typical of $\mathrm{HAW}$ glasses fabricated for DWPF. The higher $\mathrm{B}_{2} \mathrm{O}_{3}$ content does not have a dramatic negative effect on durability.

\subsubsection{Summary}

The results of BL-9 indicate that this glass meets all targeted processing and product performance constraints as defined in Table II. Higher $\mathrm{B}_{2} \mathrm{O}_{3}$ additions in the absence of $\mathrm{Al}_{2} \mathrm{O}_{3}$ does not adversely effect the processing and/or product performance of this glass. "All Blend" waste loadings of up to $19.0 \mathrm{wt} \%$ 
(translating into approximately $15.0 \mathrm{wt} \% \mathrm{ZrO}_{2}$ ) are achievable in a borosilicate system while maintaining acceptable processing constraints at $1150^{\circ} \mathrm{C}$.

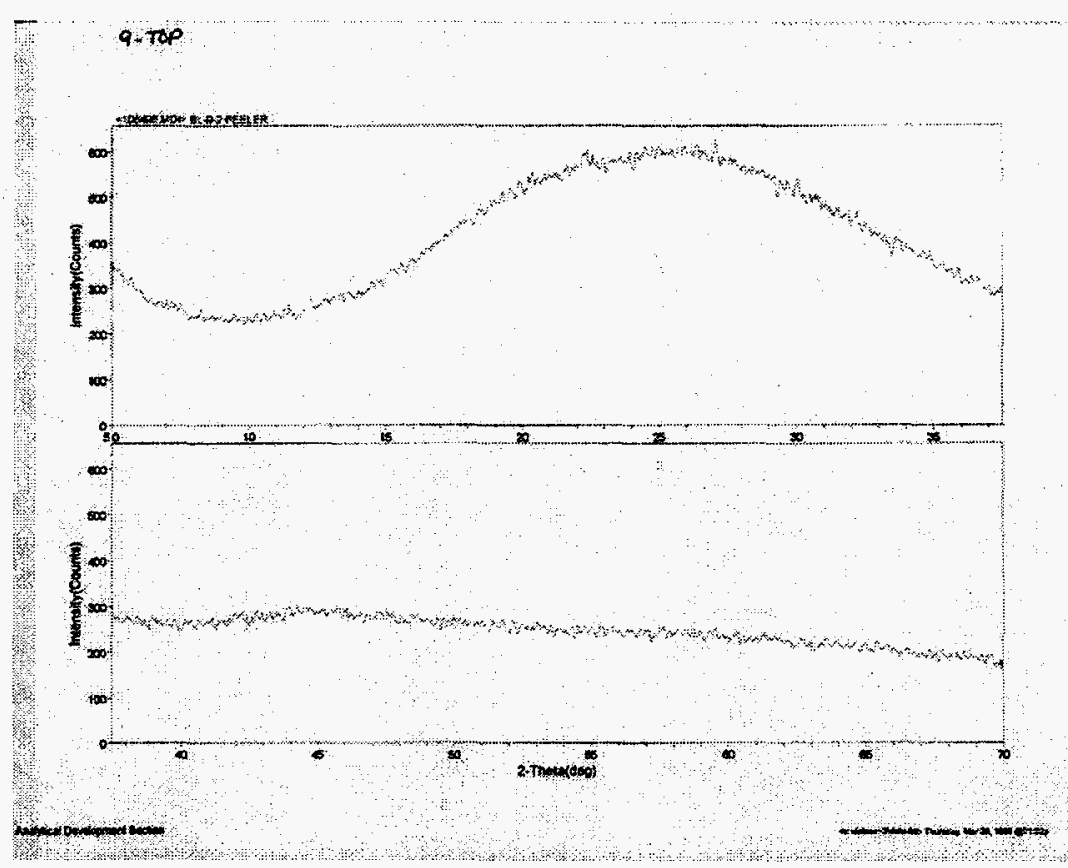

(a) Pour Patty

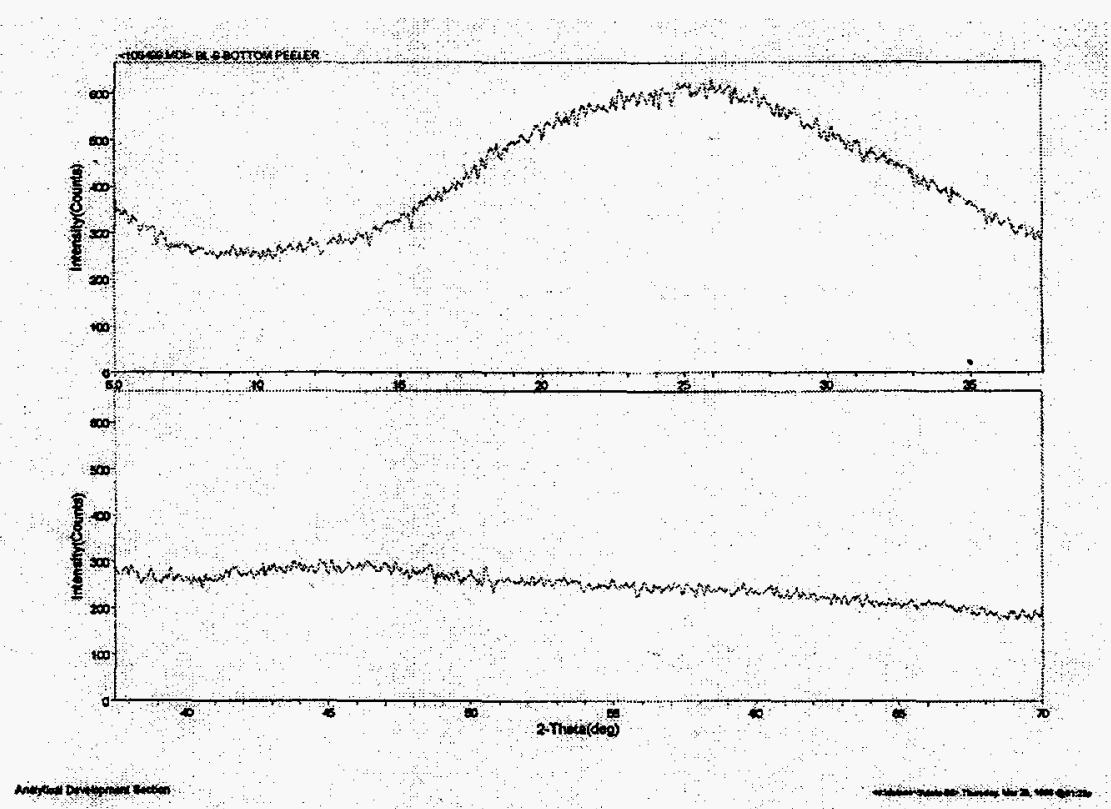

(b) Residual Crucible Glass

Figure 10. XRD Results of the "As Fabricated" BL-9 Glass. 


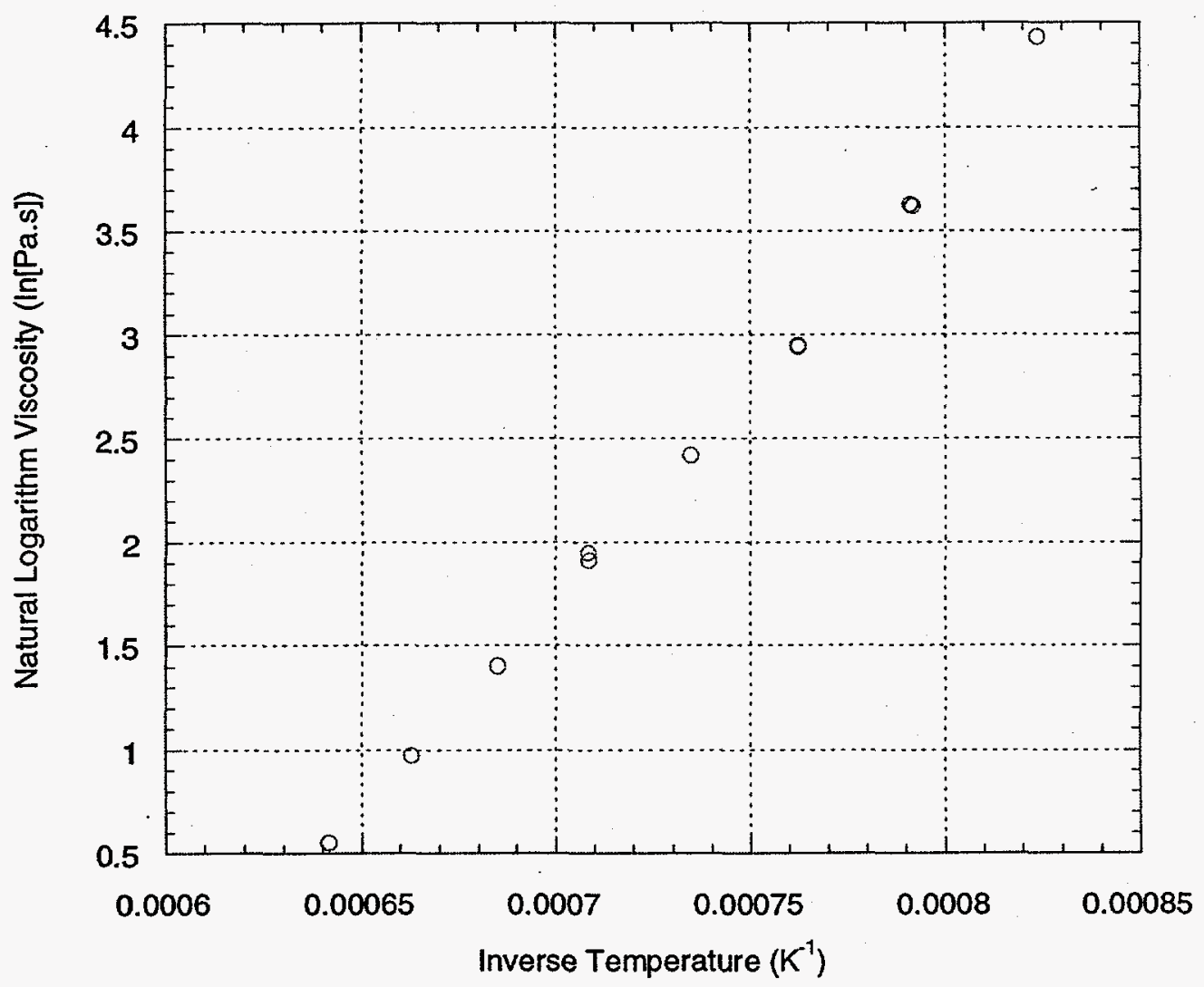

( $\ln \eta=A+B / T_{0}$ where $A=-12.833$ and $B=20,808.8 K$ )

Figure 11. High Temperature Viscosity Curve for BL-9. 


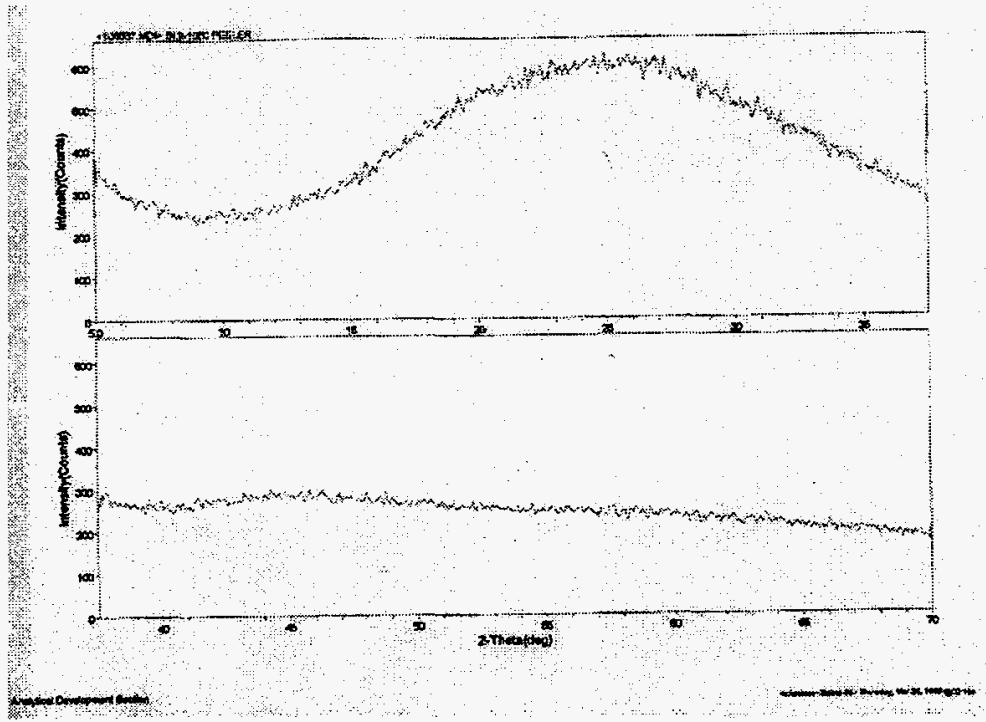

Figure 12. XRD Results of BL-9 Heat Treated at $1050^{\circ} \mathrm{C}$ for 24 Hours.

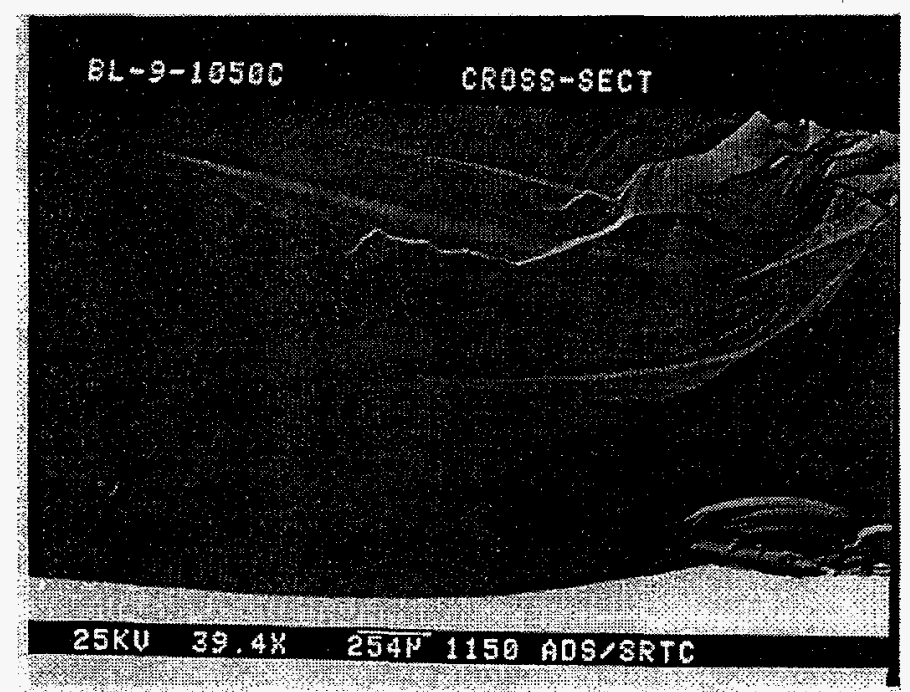

Figure 13. SEM Micrograph of BL-9 Heat Treated at $1050^{\circ} \mathrm{C}$ for 24 Hours. 


\subsubsection{Devitrification Potential}

Additional testing to reduce the technical risks associated with a $1 / 4$ scale melter run was performed in parallel with evaluation of the processing and performance criteria. ${ }^{9}$ Corrosion tests designed to evaluate the compatibility of the glass and the melter materials of construction are in progress at PNNL. The results of the corrosion tests using the BL glasses will be reported by Sudaram et al. [2]. However, not only is the compatibility of the glass with the materials of construction an issue, the current melter drain tube also presents an interesting technical issue for the glass formulation team. The current design of the $1 / 4 \mathrm{scale}$ melter has a drain tube extending from the bottom of the main melter chamber. The drain tube is equipped with process air and a heater sleeve to initiate and stop pouring based on the dependence of viscosity with temperature. To initiate pouring the process air is shut off and the heater is placed around the drain tube. As the heater transmits energy to the drain tube, the glass softens and eventually begins to flow. To stop the glass flow, the heater is removed and air is blown on the drain tube tip. This increases the viscosity of the glass in the drain tube leading to a "glass plug". Although a very workable system, this presents one technical issue regarding devitrification within the drain tube. A thermal gradient will exist along the length of the drain tube while the melter idles at $1150^{\circ} \mathrm{C}$ and air is blown on the drain tube tip. This gradient will tend to promote devitrification of any glass. Dependent upon the type and extent of crystallization, complete blockage of the drain tube could result in impeded pouring. The durability of the final product may be affected by the type and extent of crystallization. However, the effected volume of glass in the drain tube is relatively small compared to the melter glass volume. To reduce technical risks, the following key questions should be evaluated and/or addressed prior to processing a glass through this type of melter system:

What is the primary crystalline phase for the glass system being processed?

- Are the devitrification kinetics rapid?

- Does complete devitrification occur in the drain tube or is there residual glass?

- Will the primary crystalline phase remelt? If so, can the heater apply the necessary heat to the drain tube to remelt the crystals?

\footnotetext{
${ }^{9}$ The results of the durability tests on BL-4 and BL-5 were not known prior to measurement of the devitrification potential. It is now known that the durability of these two glasses limits them as potential candidates for the INEEL $1 / 4$ scale melter runs. However the additional information obtained is reported and is applicable to other glasses being considered for recommendation.
} 


\subsubsection{BL-4 and $B L-5$}

Additional tests were performed to provide limited insight into this issue. Homogeneous samples were obtained from the initial BL-4 and BL-5 melts that had been archived. These samples were isothermally heat treated at $850^{\circ} \mathrm{C}$ for 24 hours in Pt-10\%Rh crucibles to intentionally devitrify both samples. ${ }^{10} \mathrm{~A}$ unique devitrification layer was observed along the glass/air and glass/crucible interfaces in both samples. Figure 14 shows an optical photograph of each cross-section. Within the bulk of each glass, large "needlelike" crystals were visually observed. Samples of each heat treated glass were submitted to XRD and SEM/EDS for analysis. Figures 15 and 16 show the XRD results for BL-4 (HT 850) and BL-5 (HT 850), respectively. Parakeldyshite $\left(\mathrm{Na}_{2} \mathrm{ZrSi}_{2} \mathrm{O}_{7}\right)$ was observed in both samples (same phase as that observed in BL-2, see Section 5,1.2). Lithium silicate was only observed in BL-5 (HT 850) which utilized Frit \#2 with the higher $\mathrm{Li}_{2} \mathrm{O}$ content (refer to Table VIII). There was no attempt to obtain quantitative information from XRD regarding the volume percent crystallization in either sample. However, based on visual observations and optical microscopy results, the estimated volume percent is relatively high (approximately $50 \%$ ).

SEM/EDS confirmed both visual observations and XRD results. Micrographs and EDS spectra of BL-4 (HT 850) are shown in Figures 17 - 20. Figure 17 shows a SEM back-scatter, cross-sectional image of the BL-4 (HT 850) glass (left side of micrograph is the glass/air interface; right side is the glass/crucible (bottom) interface). The dense layer of crystals visually observed at these two interfaces is very apparent in the SEM micrograph. Large "needle-like" crystals (on the order of $200-800 \mu \mathrm{m}$ ) are also observed within the bulk of BL-4 (HT 850). Figure 18 shows the corresponding EDS spectra of a representative crystal within the dense surface layer. EDS indicates the presence of $\mathrm{Na}, \mathrm{Si}$, and $\mathrm{Zr}$ as the primary elements associated with the crystalline phase which supports the XRD results (shown in Figure 15) indicating $\mathrm{Na}_{2} \mathrm{ZrSi}_{2} \mathrm{O}_{7}$. EDS spectra of the "bulk" crystallization (large "needle-like" crystals isolated in the bulk glass) and the corresponding SEM micrograph are shown in Figures 19 and 20, respectively. Again, Na, $\mathrm{Si}$, and $\mathrm{Zr}$ are the elements associated with this crystalline phase as determined by $\mathrm{XRD}\left(\mathrm{Na}_{2} \mathrm{ZrSi}_{2} \mathrm{O}_{7}\right)$.

Figure 21 shows a SEM back-scatter, cross-sectional image of the BL-5 heat treated glass (top of micrograph is the glass/air interface; bottom of micrograph is the glass/crucible (bottom) interface). As with BL-4 (HT 850), the dense layer of crystallization characterizes the glass/air interface with large "needle-like" crystals (on the order of $200-800$ microns) isolated within the bulk of the glass. Figure 22 shows an EDS spectra of a representative crystal within the glass-air interface zone. $\mathrm{Na}, \mathrm{Si}$, and $\mathrm{Zr}$ are the primary elements associated with this crystalline phase which support the XRD results (shown in Figure 16). It should be noted that some crystals within the glass/air interface have a different crystal habit than those observed in the bulk. Although the habit is different, it appears that the same elements (Na, Si, and $\mathrm{Zr}$ ) are associated. Figures 23 and 24 respectively show a representative crystal from the bulk glass with 
the corresponding EDS spectra. Lithium silicate was also detected in the XRD pattern however $\mathrm{Li}$ can not be detected by the EDS being utilized. Therefore, the presence of $\mathrm{Li}_{2} \mathrm{SiO}_{3}$ can not be confirmed by SEM/EDS.

These results suggests that if the melter is idled (no pouring) and temperatures in the $800-900^{\circ} \mathrm{C}$ range are experienced by either glass system (BL-4 and BL-5), there is a high likelihood that devitrification will occur. However, complete devitrification kinetics for this specific glass are not known. That is, all possible time / temperature combinations and the resulting kinetics of crystallization were not evaluated. Coupled with previous tests, the liquidus temperature can be bounded between $850-1050^{\circ} \mathrm{C}$ (i.e., isothermal hold for 24 hours at $1050^{\circ} \mathrm{C}$ produced no devitrification, see Section 5.2.1.3). Devitrification may be avoided or minimized by limiting the idling time of the melter.

Again, this additional data was being developed in parallel with the processing and product performance testing. As discussed in Sections 5.2.1.4 and 5.2.1.5, the durability of these two glasses are inadequate thus eliminating them as potential candidates for the $1 / 4$ scale melter run.

\footnotetext{
${ }^{10}$ Note that based on the specific melter operating conditions, which includes idling times and temperatures, devitrification potential will vary.
} 


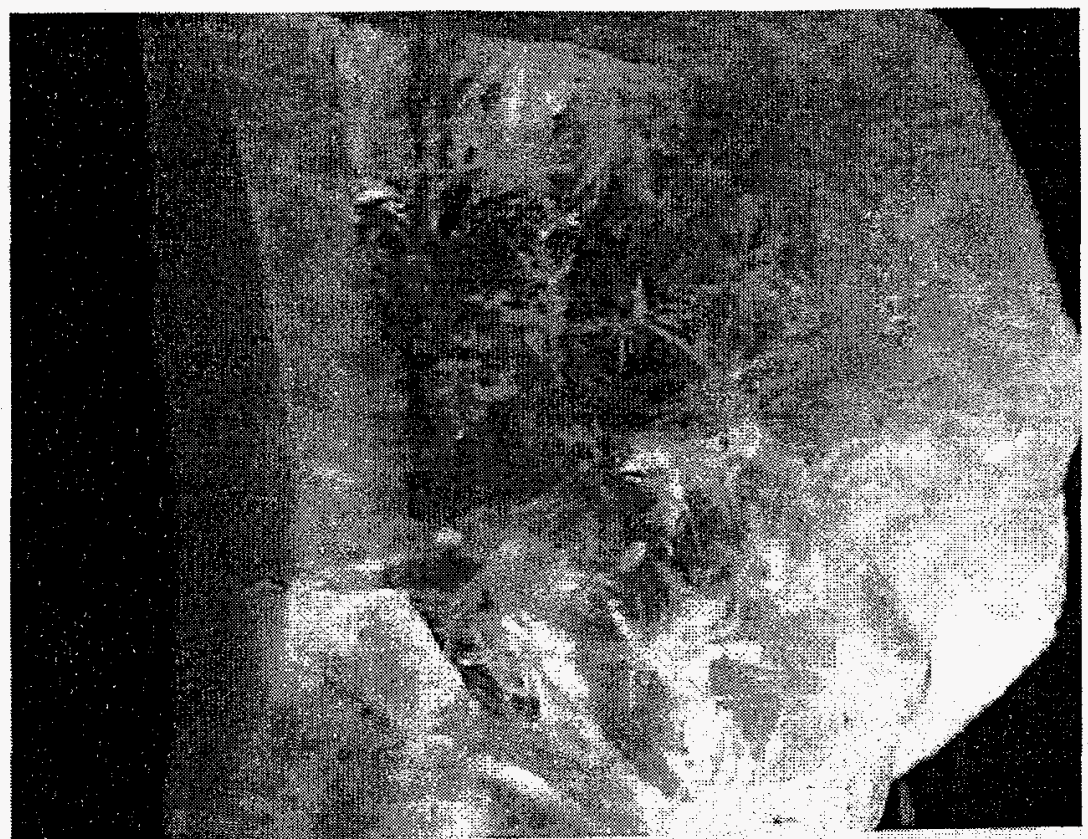

18.3 1NEEL A-C1

(a) BL-4 (HT 850)

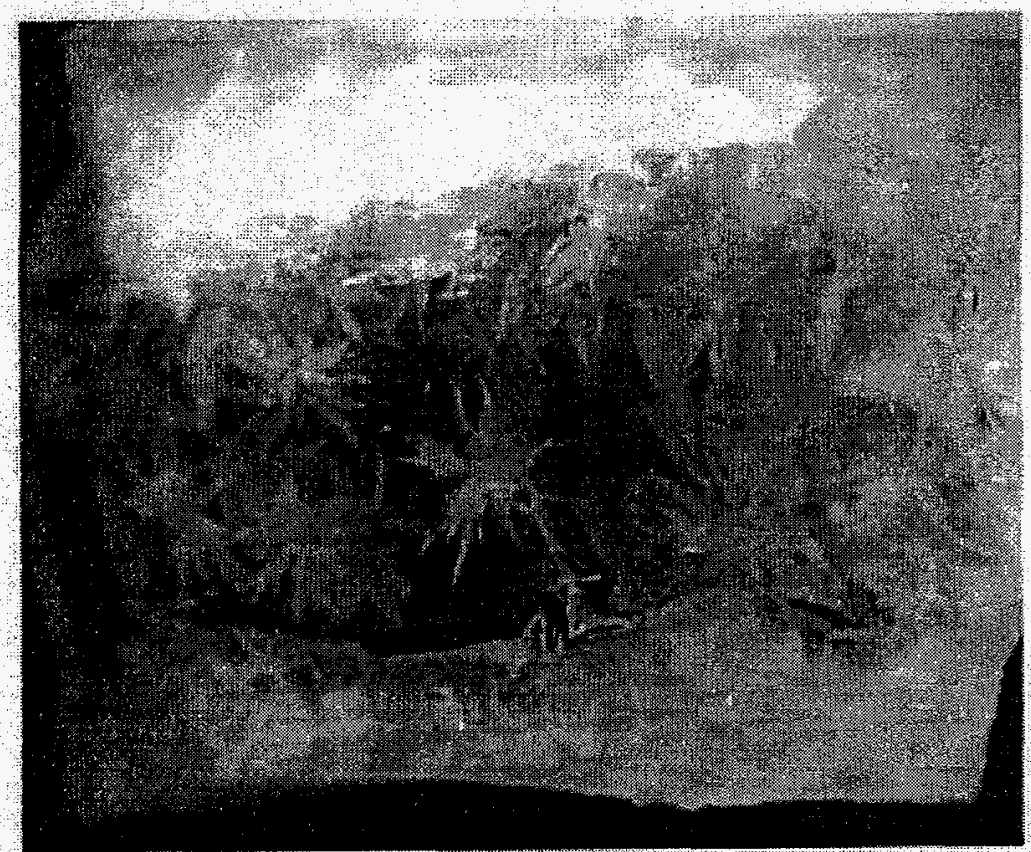

AIAEE $1-2858$

(b) BL-5 (HT 850)

Figure 14. Optical Micrographs of (a) BL-4 (HT 850)

and (b) BL-5 (HT 850). 


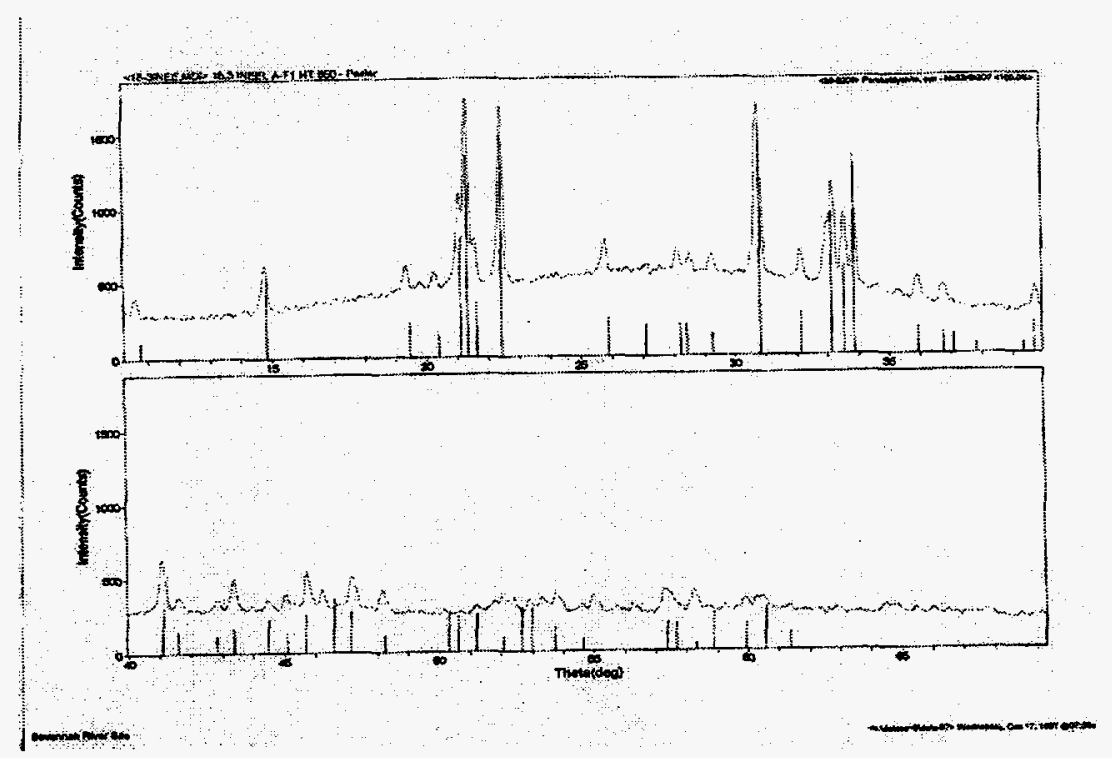

Figure 15. XRD Results of BL-4 (HT 850).

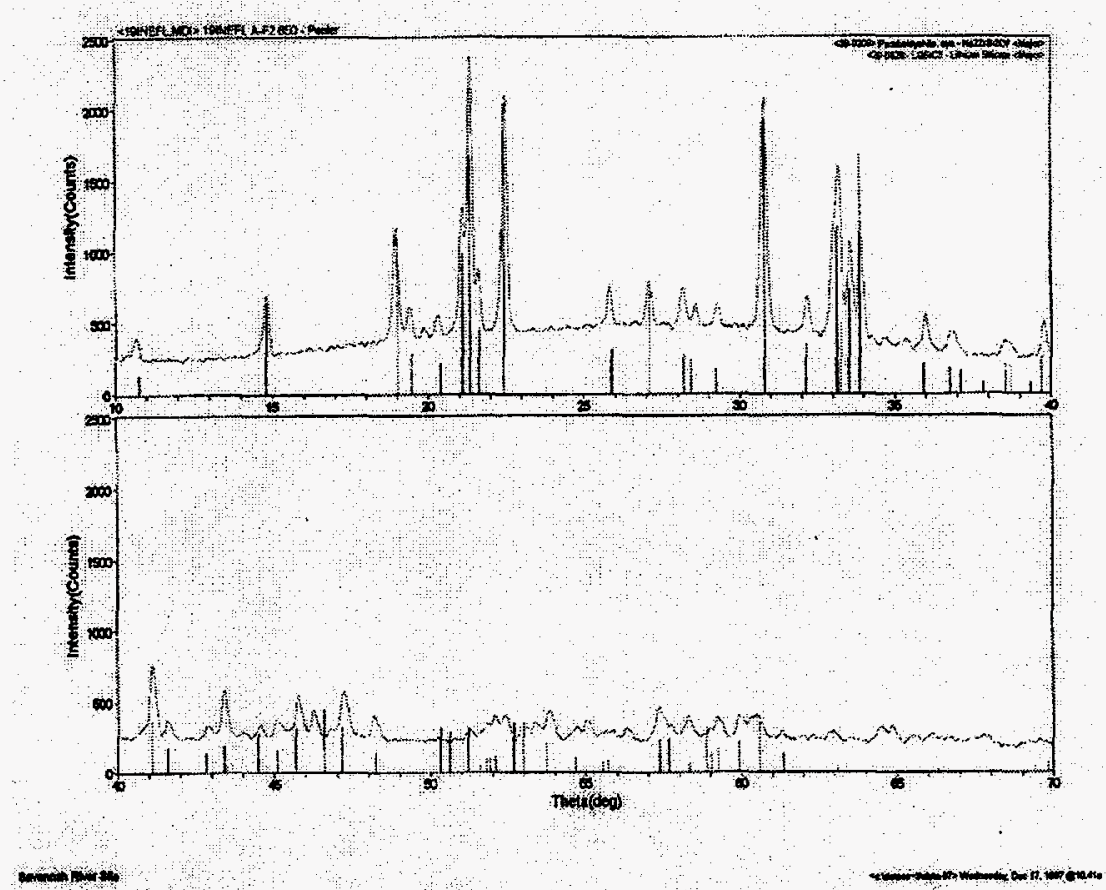

Figure 16. XRD Results of BL-5 (HT 850). 


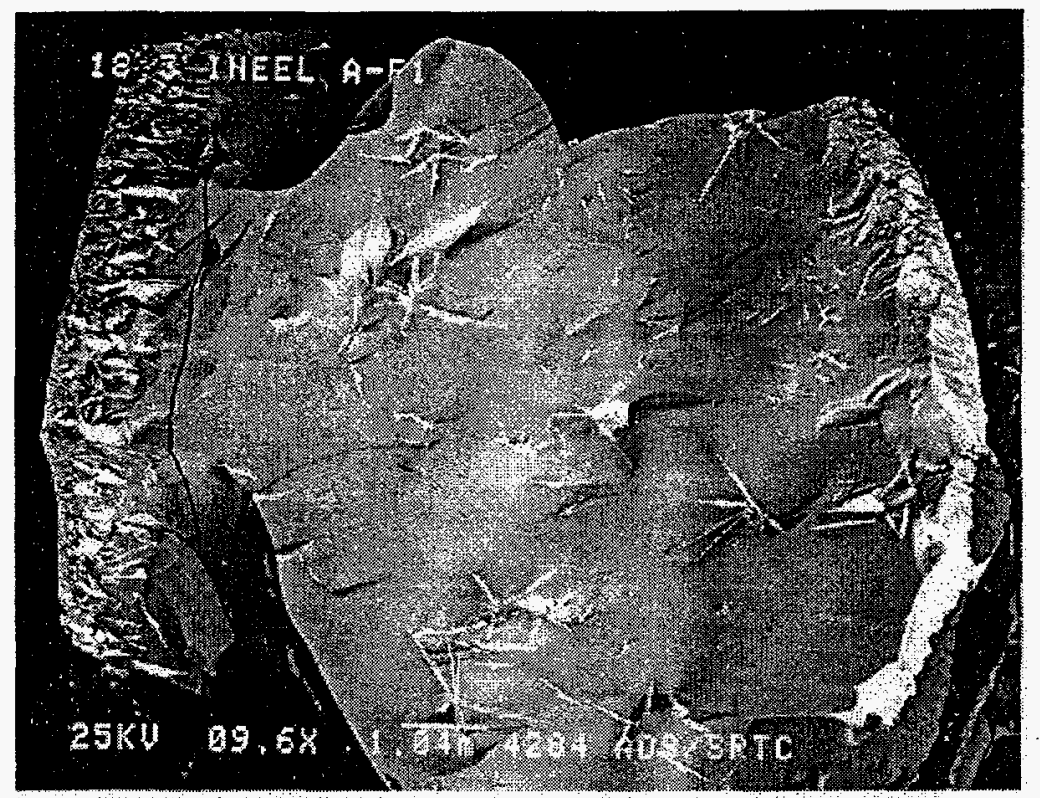

Figure 17. SEM Micrograph of BL-4 (850 HT) - Cross Sectional Image.

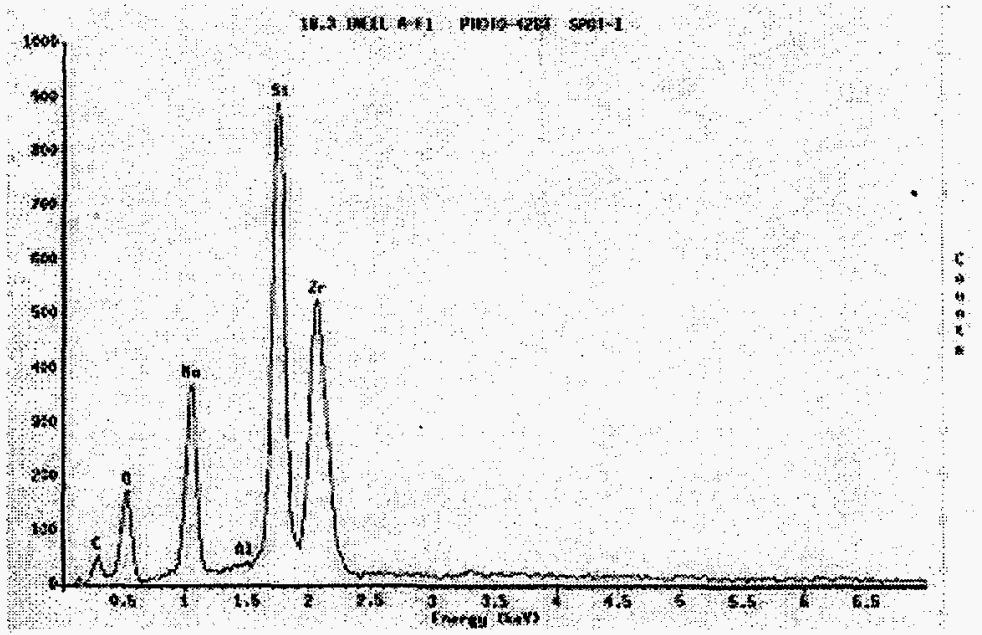

Figure 18. EDS Spectra of a Crystal Within the Dense Surface Layer (BL-4 $(850 \mathrm{HT})$ ). 


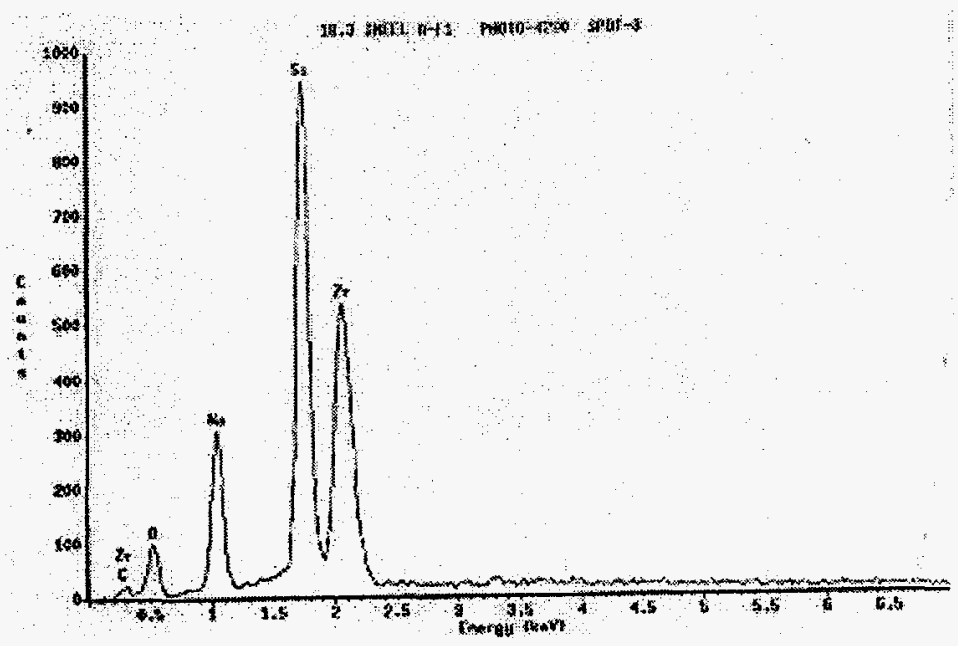

Figure 19. EDS Spectra of "Bulk Crystallization" (BL-4 (850 HT)).

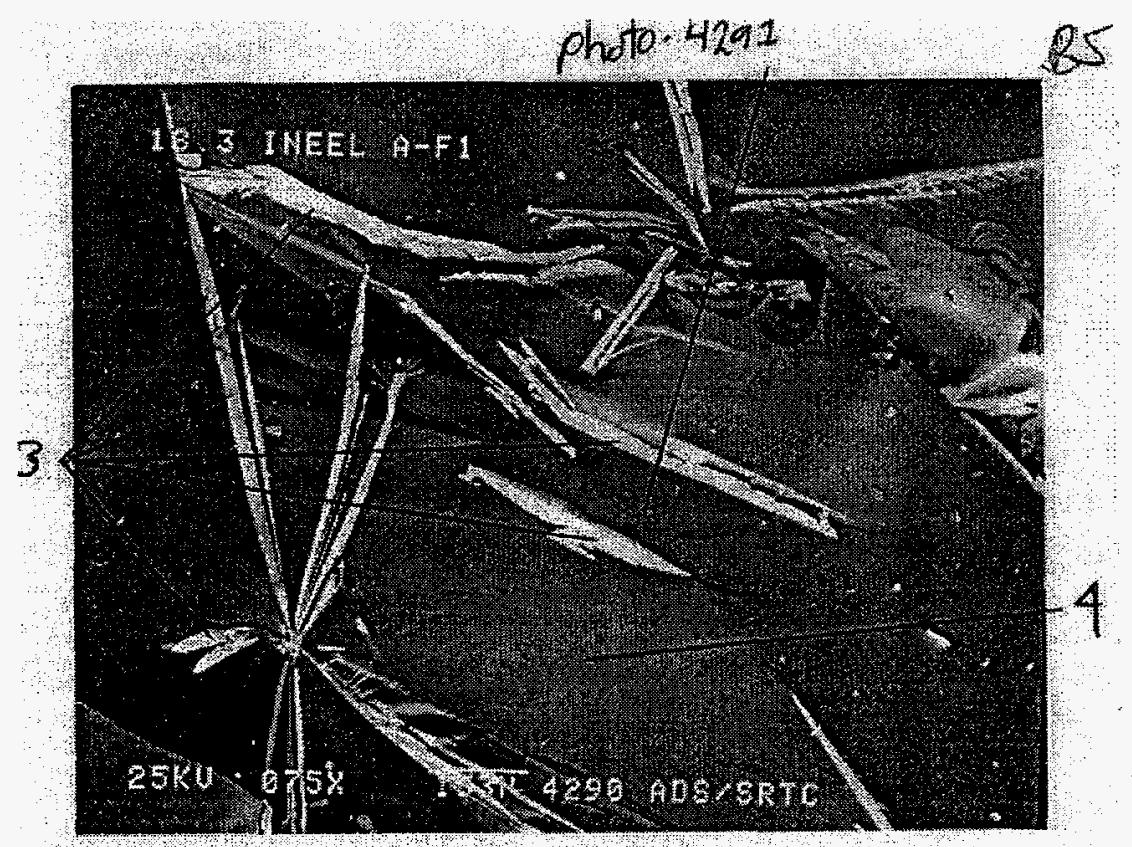

Figure 20. SEM Micrograph of "Bulk Crystallization" (BL-4 (850 HT)). 


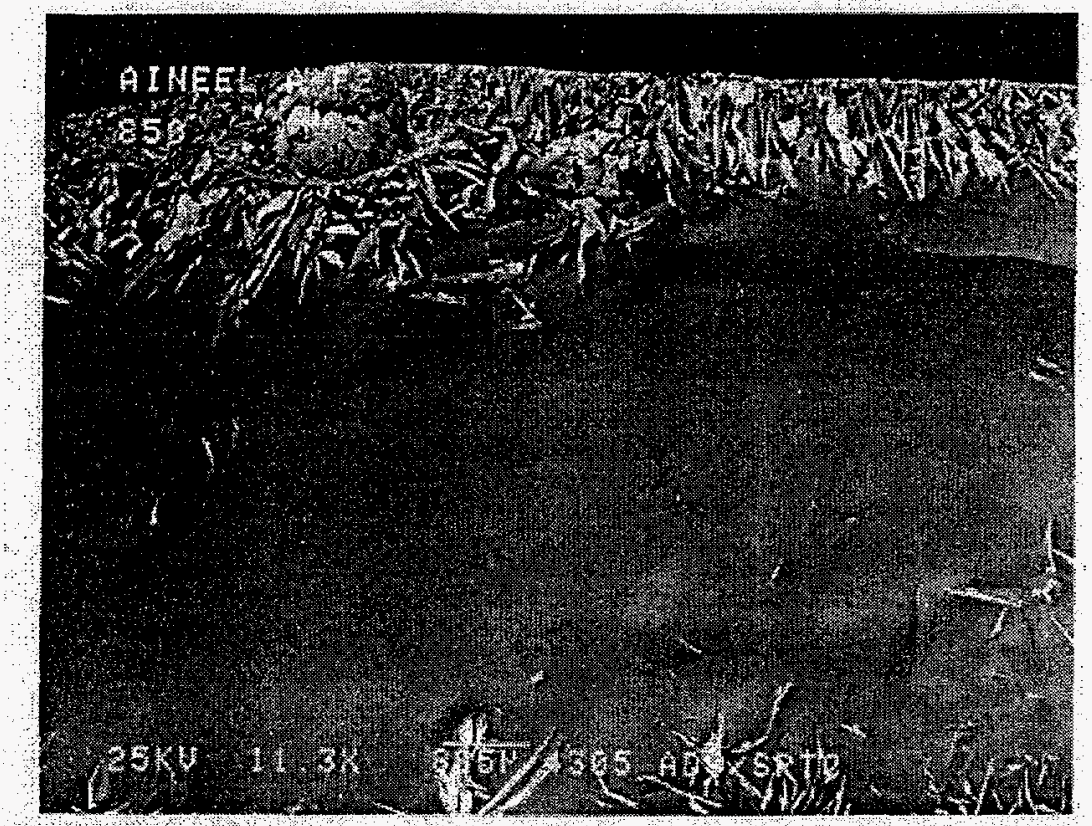

Figures 21. SEM Micrograph of BL-5 (HT 850) - Cross Sectional Image.

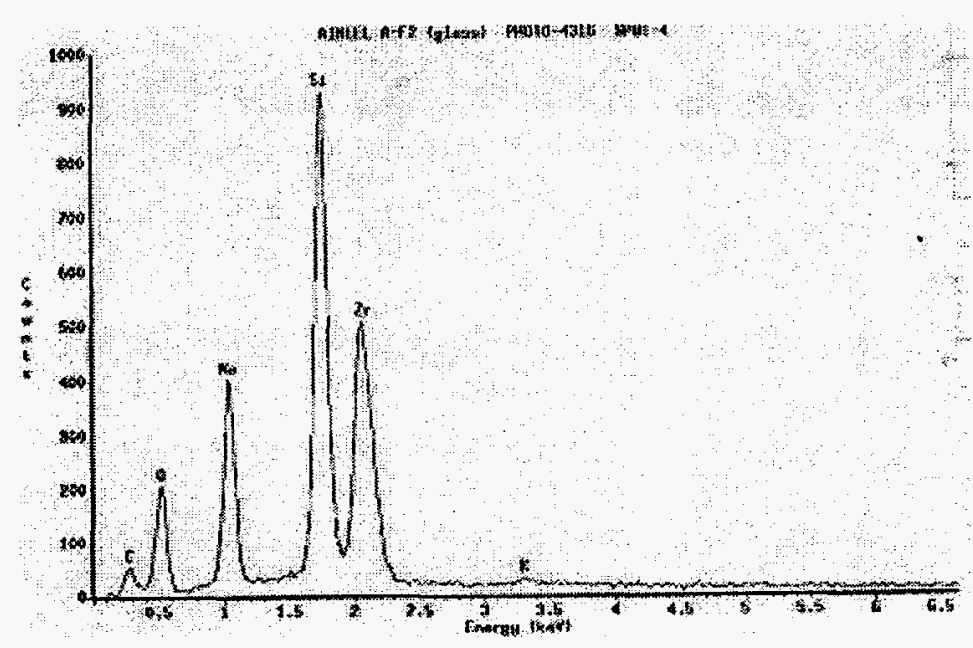

Figure 22. EDS Spectra of a Crystal Within the Dense Surface Layer (BL-5 (HT 850)). 


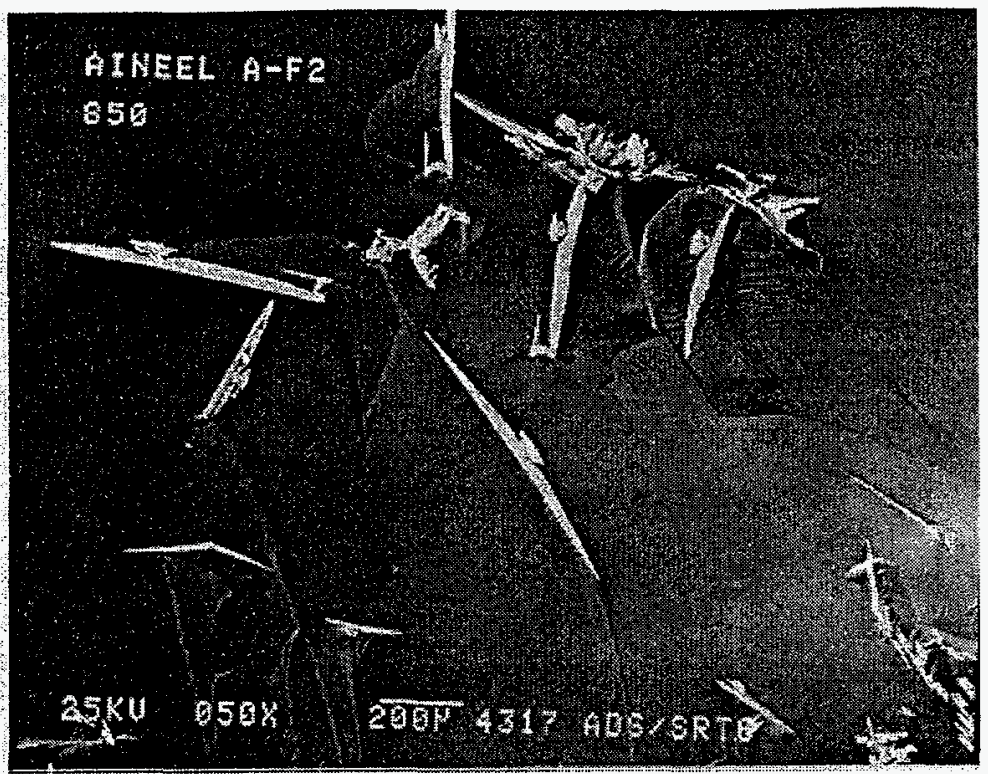

Figure 23. SEM Micrograph of "Bulk Crystallization" (BL-5 (850 HT)).

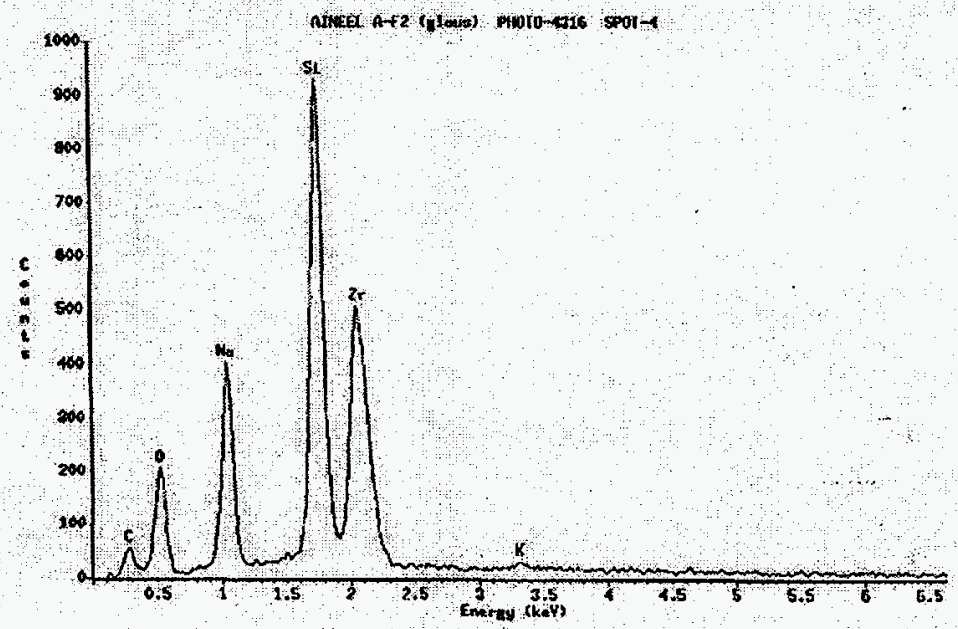

Figure 24. EDS Spectra of "Bulk Crystallization" (BL-5 (850 HT)). 


\subsubsection{BL-8 and BL-9}

As discussed in Section 5.6, additional tests were performed to provide limited insight into the potential for devitrification within the drain tube. Homogeneous samples were obtained from the initial BL-8 and BL-9 melts that had been archived. These samples were isothermally heat treated at $850^{\circ} \mathrm{C}$ for 24 hours in Pt$10 \%$ Rh crucibles to intentionally devitrify both samples. ${ }^{11}$

Optical micrographs of BL-8 (HT 850) and BL-9 (HT 850) are shown in Figure 25. Few crystals (later identified as $\mathrm{Na}_{2} \mathrm{Zr}_{2} \mathrm{SiO}_{7}$ by XRD) are observed in BL-8 (HT 850) and even fewer in BL-9 (HT 850). These glasses show markedly less crystallization than in BL-4 and BL-5 glass after the 24 hour heat treatment at $850^{\circ} \mathrm{C}$ (compared to Figure 14).

Figures 26 and 27 show the XRD results for BL-8 (HT 850) and BL-9 (HT 850), respectively. Parakeldyshite $\left(\mathrm{Na}_{2} \mathrm{ZrSi}_{2} \mathrm{O}_{7}\right)$ was observed in the BL-8 (HT 850) sample (the same phase as that observed in BL-4 (HT 850) and BL-5 (HT 850)). The weak peaks associated with the BL-9 (HT 850) sample suggest Baddeleyite $\left(\mathrm{ZrO}_{2}\right)$ as the crystalline phase. Lithium silicate was not observed in either BL-8 (HT 850 ) or BL-9 (HT 850). Semi-quantitative analysis of XRD data showed a $3.7 \mathrm{vol} \%$ and $1.2 \mathrm{vol} \%$ crystallization in the samples of BL-8 $(850 \mathrm{HT})$ and BL-9 $(850 \mathrm{HT})$, respectively. ${ }^{12}$ Tests at the partnering laboratory confirmed Parakeldyshite $\left(\mathrm{Na}_{2} \mathrm{ZrSi}_{2} \mathrm{O}_{7}\right)$ as the primary crystalline phase in the BL-8 (HT 850) (see Figure 28). However, based on the XRD run parameters no crystals were identified in BL-9 (HT 850) by the partnering laboratory (see Figure 29).

SEM/EDS confirmed both visual observations and XRD results. Figure 30 shows a SEM backscatter image of two BL-8 (HT 850) samples. The sample on the left hand side of the micrograph is representative of the glass/crucible (bottom) interface. A dense layer of "block-like" crystals (on the order of $100-400$ $\mu \mathrm{m})$ is observed at the glass/platinum interface. The sample on the right hand side represents a crosssectional view in which very few (if any) crystals are observed. Figures 31 and 32 respectively show a higher magnification micrograph (200x) of the surface crystallization and the corresponding EDS spectra. EDS indicates the presence of $\mathrm{Na}, \mathrm{Si}$, and $\mathrm{Zr}$ as the primary elements associated with the crystalline phase which supports the XRD results (shown in Figures 26 and 28) indicating $\mathrm{Na}_{2} \mathrm{ZrSi}_{2} \mathrm{O}_{7}$. Figure 33 shows a higher magnification of the BL-8 (HT 850) cross-section.

Figures 34 and 35 show SEM back-scatter images of BL-9 (HT 850) samples representing the glass/crucible interface and cross-sectional view, respectively. Unlike the BL-8 (HT 850), very few crystals are observed at the glass/crucible interface. Figures 36 and 37 show higher magnification

\footnotetext{
11 Note that based on the specific melter operating conditions, which includes idling times and temperatures, devitrification potential will vary.

12 Note semi-quantitative analysis of XRD data (according to specific procedures used in this study is accurate to within $\pm 50 \%$ of the estimated value).
} 
micrographs of the limited surface crystallization associated with BL-9 (HT 850) and the corresponding EDS spectra (Figure 38). EDS indicates the presence of $\mathrm{Si}$ and $\mathrm{Zr}$ as the primary elements associated with the crystalline phase. The limited amount of devitrification in the BL-9 (HT 850) sample was estimated to be 1.2 vol\%. A representative SEM cross-sectional image in which no crystallization was observed was shown in Figure 35.

These results suggests that if the melter is idled and temperatures in the $800-900^{\circ} \mathrm{C}$ range are experienced by either glass (BL-8 or BL-9), there is a high likelihood that devitrification will occur. Based on the $850^{\circ} \mathrm{C}$ heat treatment, the degree of crystallization is extremely low (compared to the devitrification observed in BL-4 and BL-5). However, devitrification kinetics for these specific glasses are not known. That is, all possible time / temperature combinations and the resulting kinetics of crystallization were not evaluated. To identify the temperature of maximum crystallization, these glasses (BL-8 and BL-9) should be subjected to a 24 hour heat treatment in a linear temperature gradient furnace. 


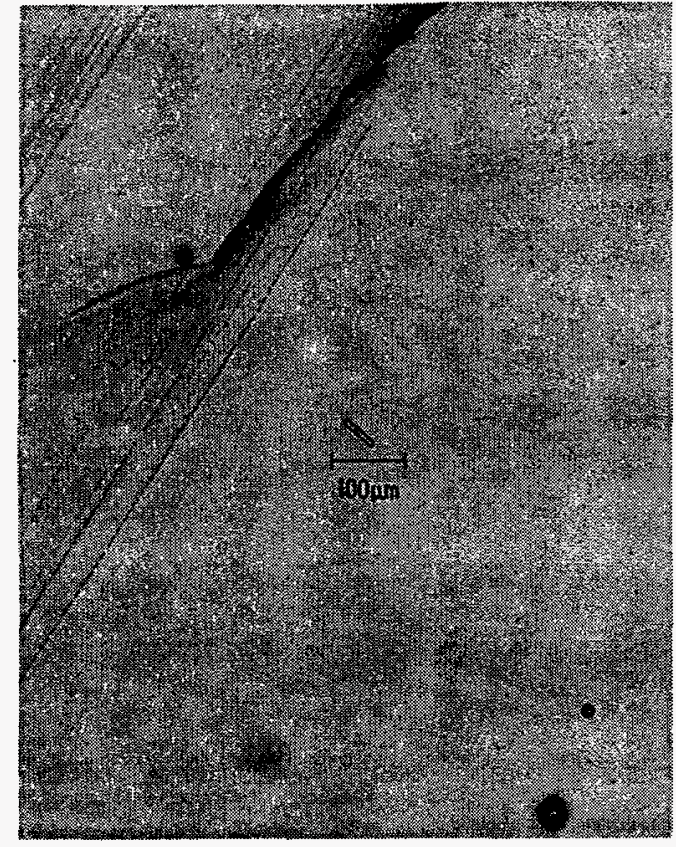

INEL-BL-9, $850^{\circ} \mathrm{C} / 24 \mathrm{hr}, 100 \times$

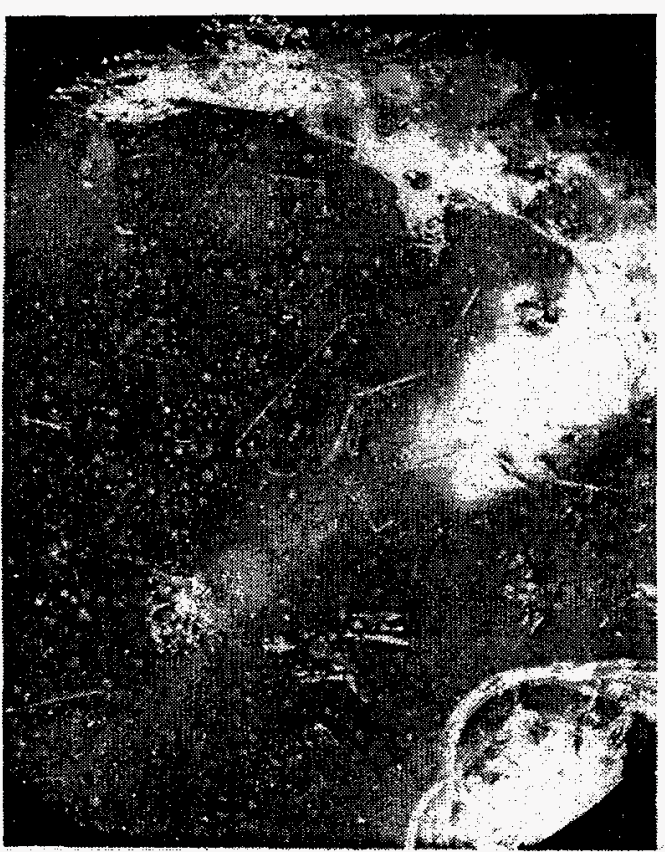

INEL-BL-9, $850^{\circ} \mathrm{C} / 24 \mathrm{hr}, 70 \mathrm{X}$

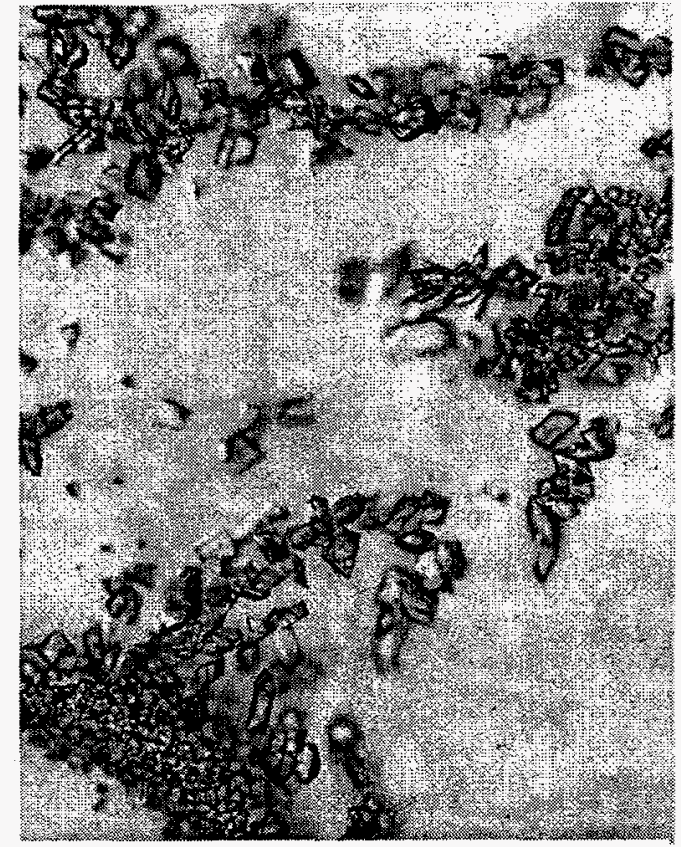

INEL-BL-8, $850^{\circ} \mathrm{C} / 24 \mathrm{hr}, 100 \times$

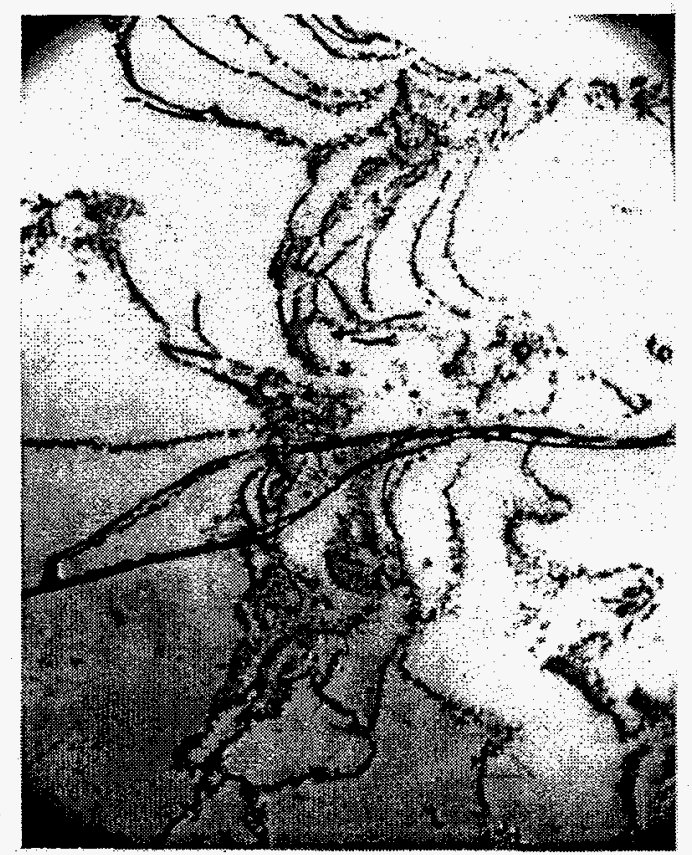

INEL-BL-8, $850^{\circ} \mathrm{C} / 24 \mathrm{hr}, 15 \times$

Figure 25. Optical Micrographs of BL-8 (HT 850) and BL-9 (HT 850). 


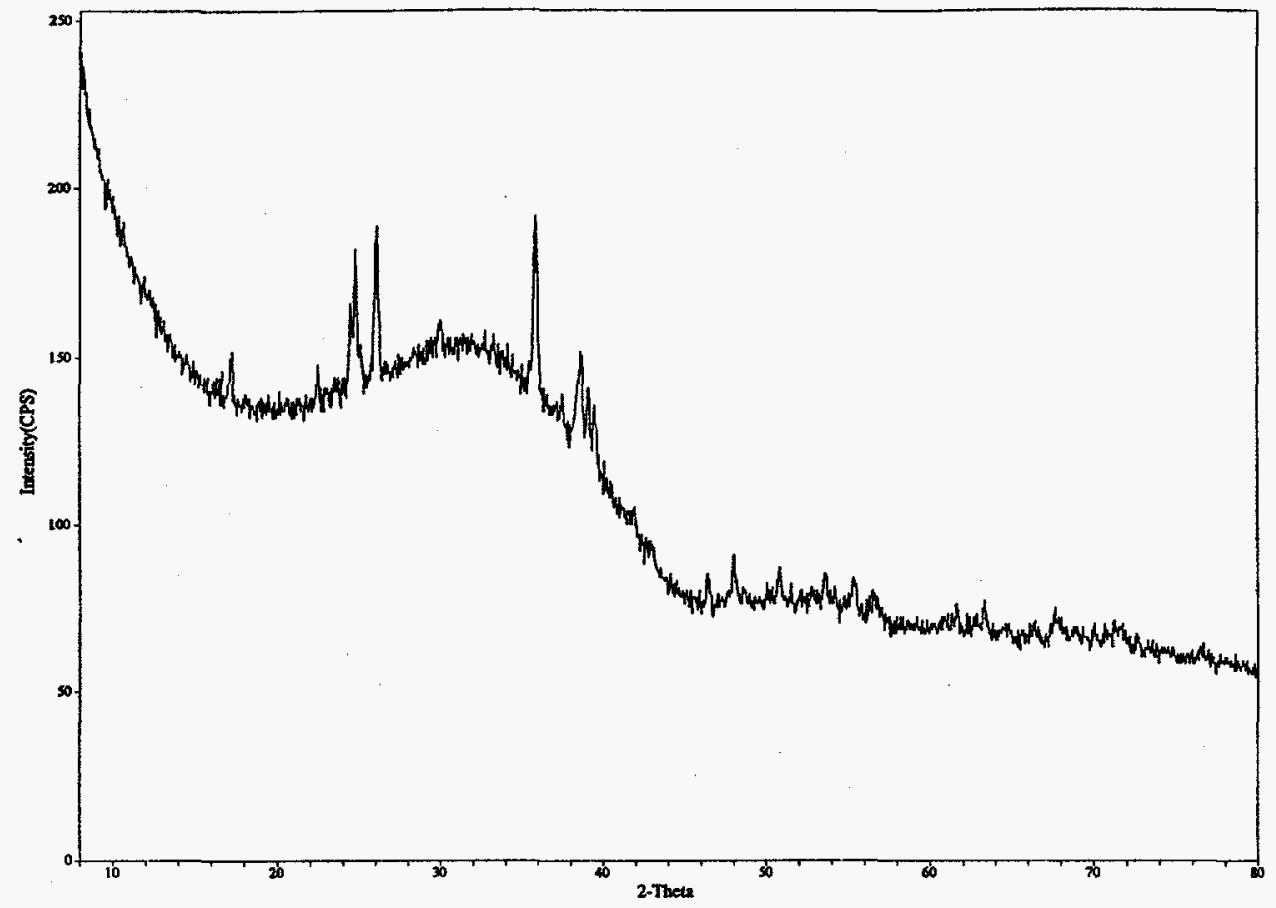

Figure 26. XRD Results of BL-8 (HT 850).

(Parakeldyshite identified as the crystalline phase)

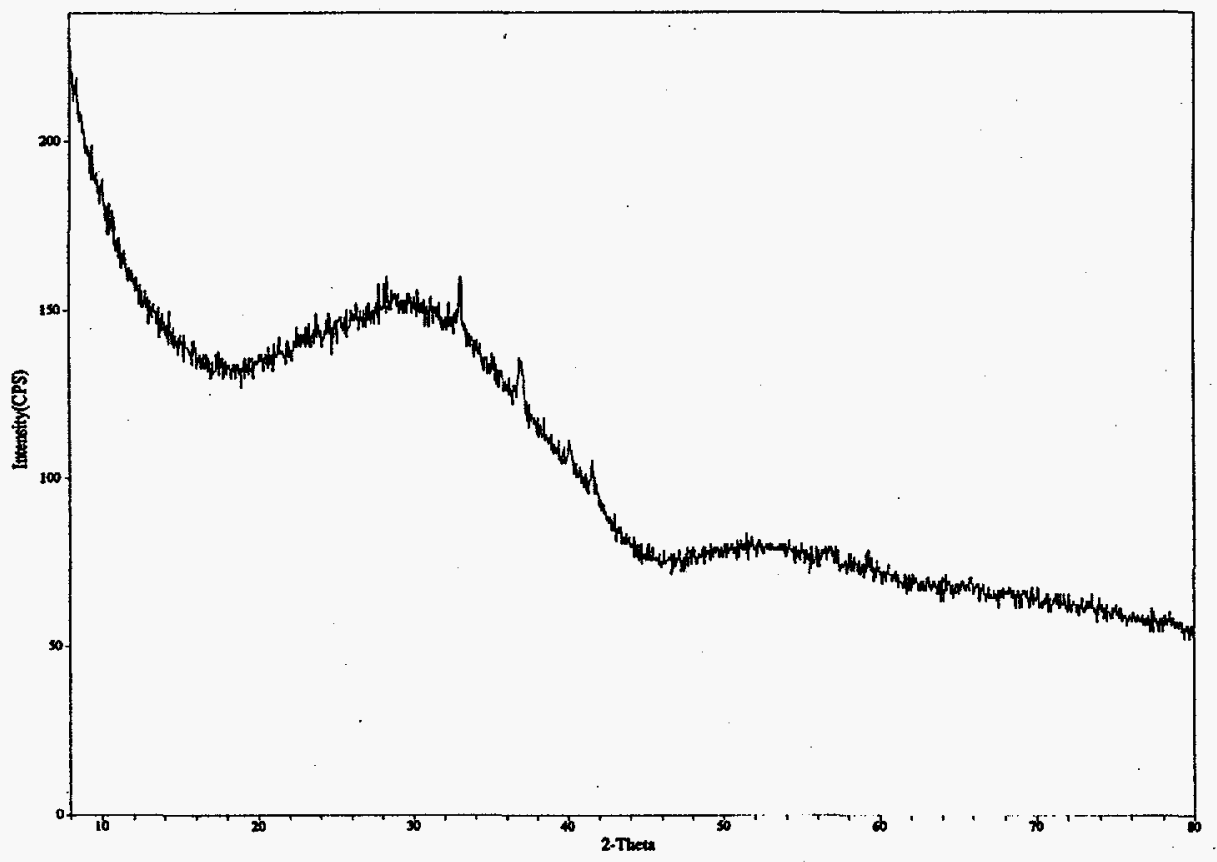

Figure 27. XRD Results of BL-9 (HT 850).

(The small peaks suggest Baddeleyite $\left(\mathrm{ZrO}_{2}\right)$ as the crystalline phase) 


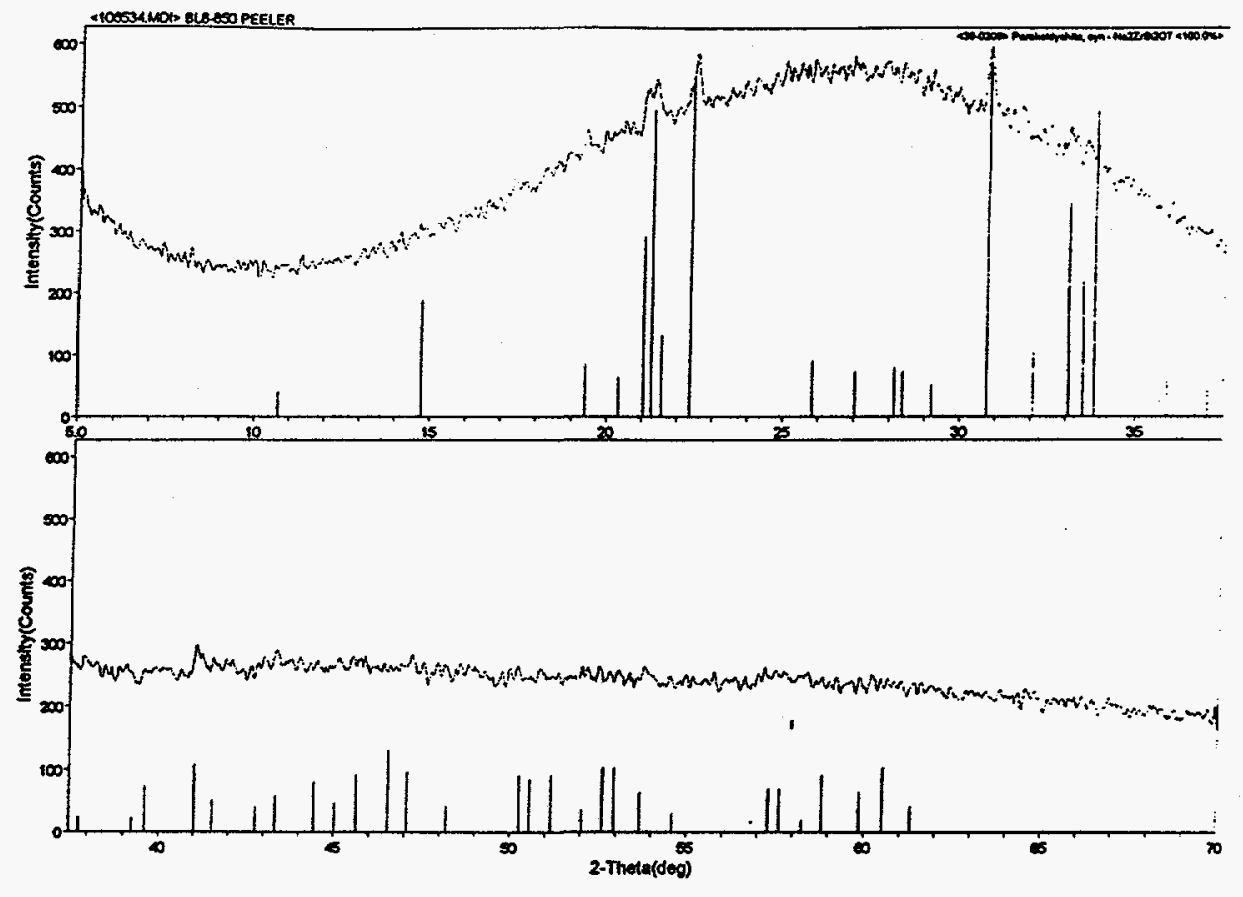

Figure 28. XRD Results of BL-8 (HT 850) from Partnering Laboratory.

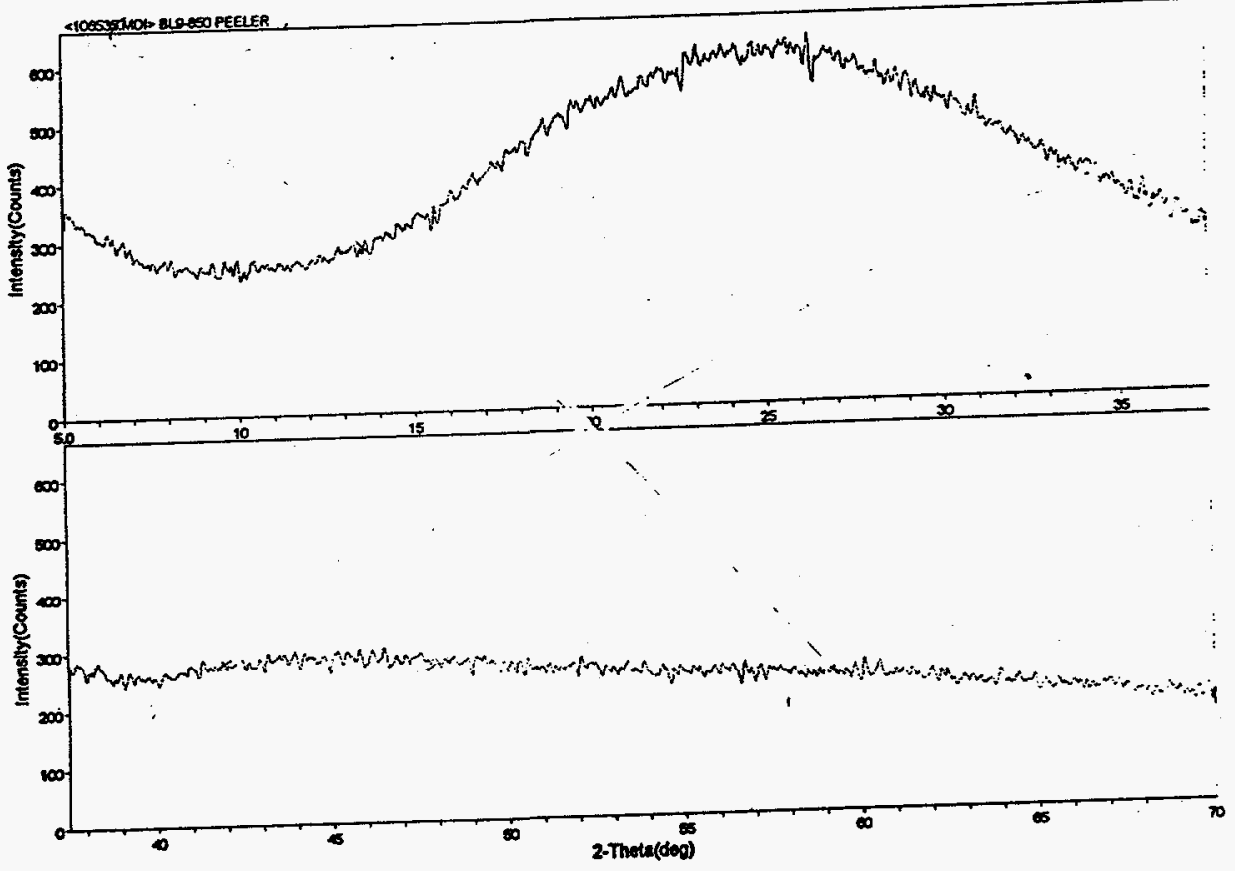

Figure 29. XRD Results of BL-9 (HT 850) Partnering Laboratory. 


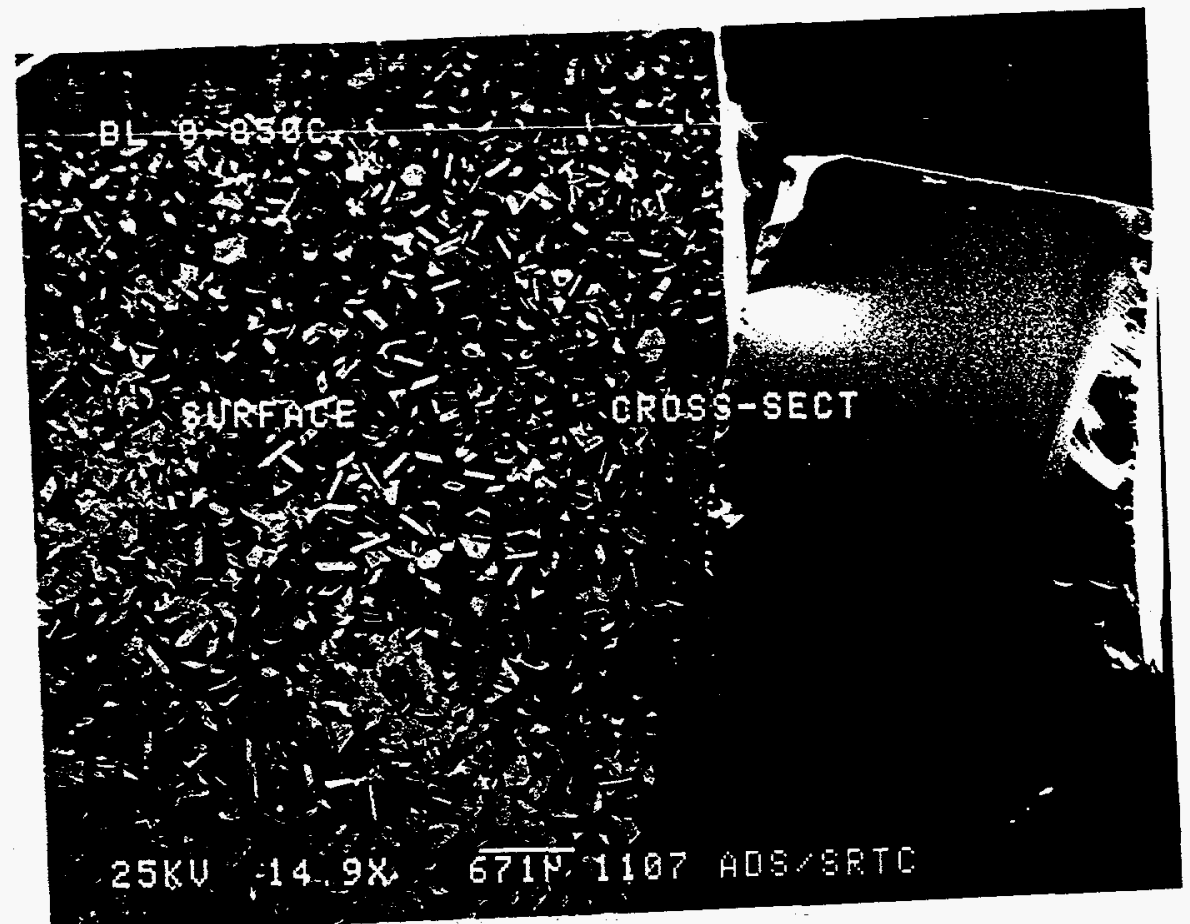

Figure 30. SEM Micrograph of BL-8 (HT 850).

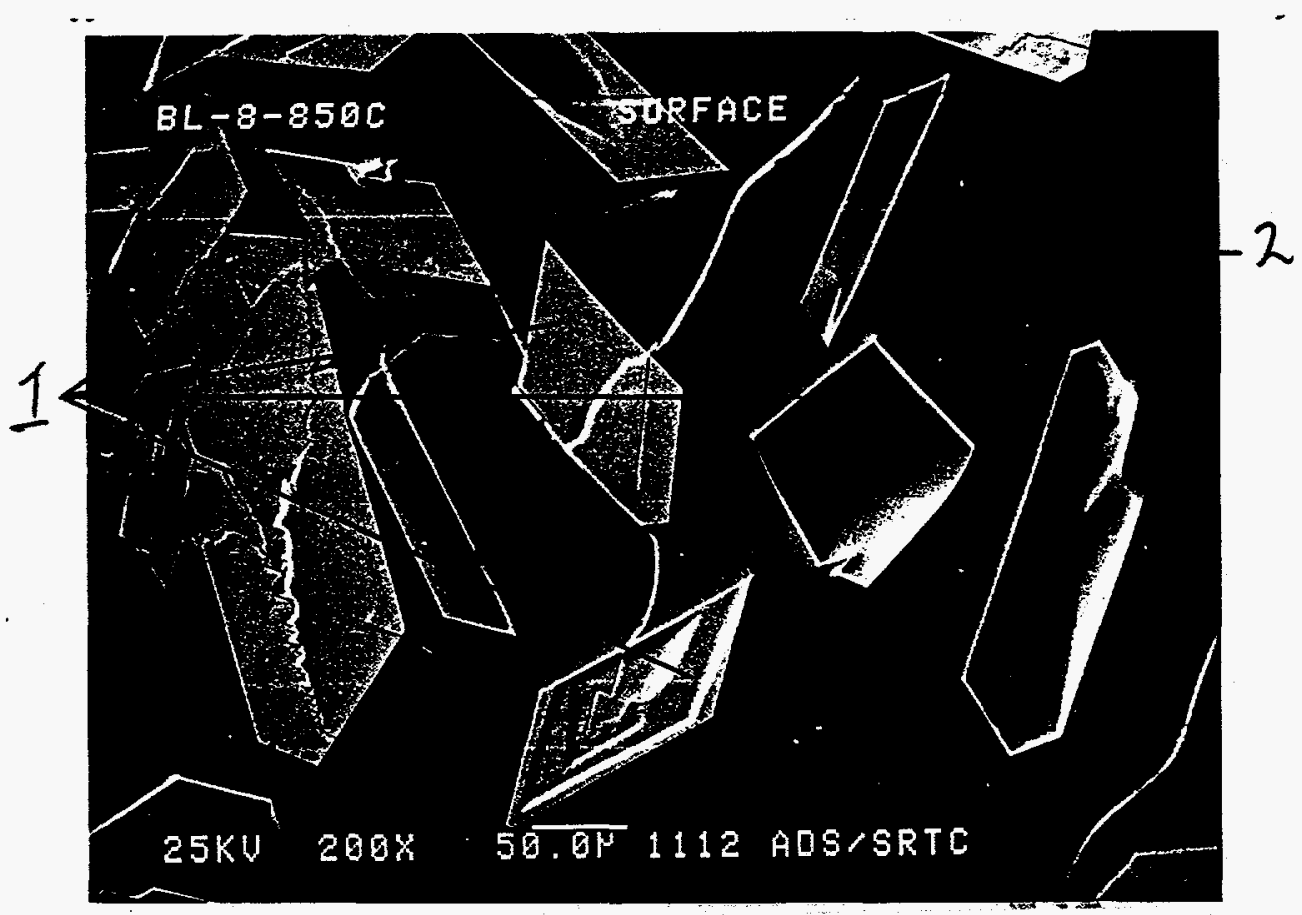

Figure 31. SEM Micrograph of "Surface Crystallization" (BL-8 (HT 850)). 


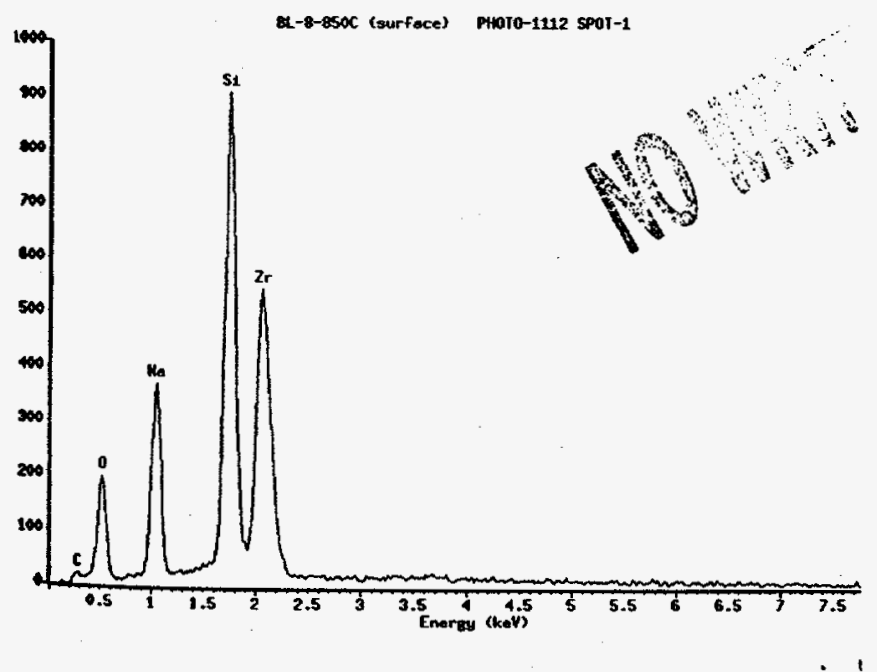

Figure 32. EDS Spectra of "Surface Crystallization" (BL-8 (HT 850)).

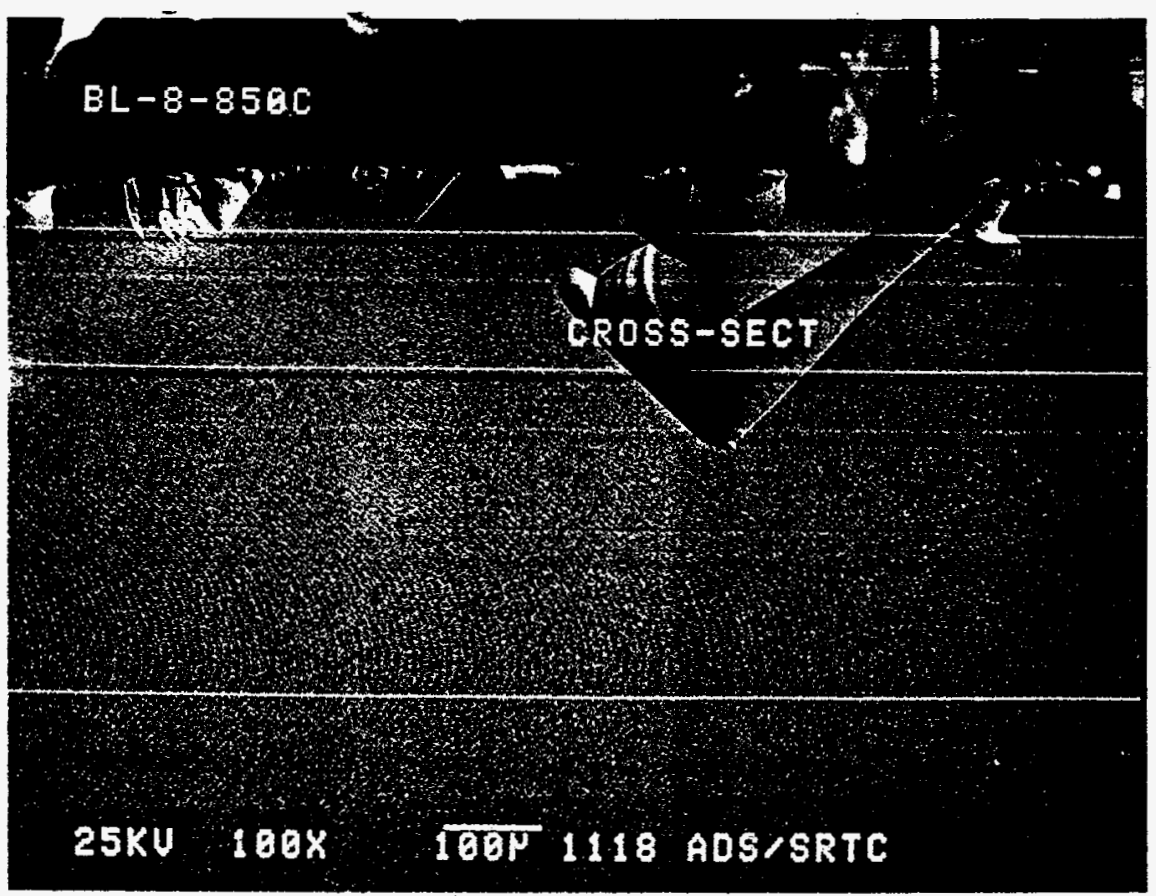

Figure 33. SEM.Micrograph of BL-8 (HT 850) - Cross Sectional Image. 


\section{$B L-9-850 C \quad \cdot \quad$ SURFACE}

\section{$25 K V \quad 15.0 X \quad 667 \mathrm{~T} 1121 \mathrm{ADS} / S \mathrm{RTC}$}

Figure 34. SEM Micrograph of "Surface Crystallization" (BL-9 (HT 850)).

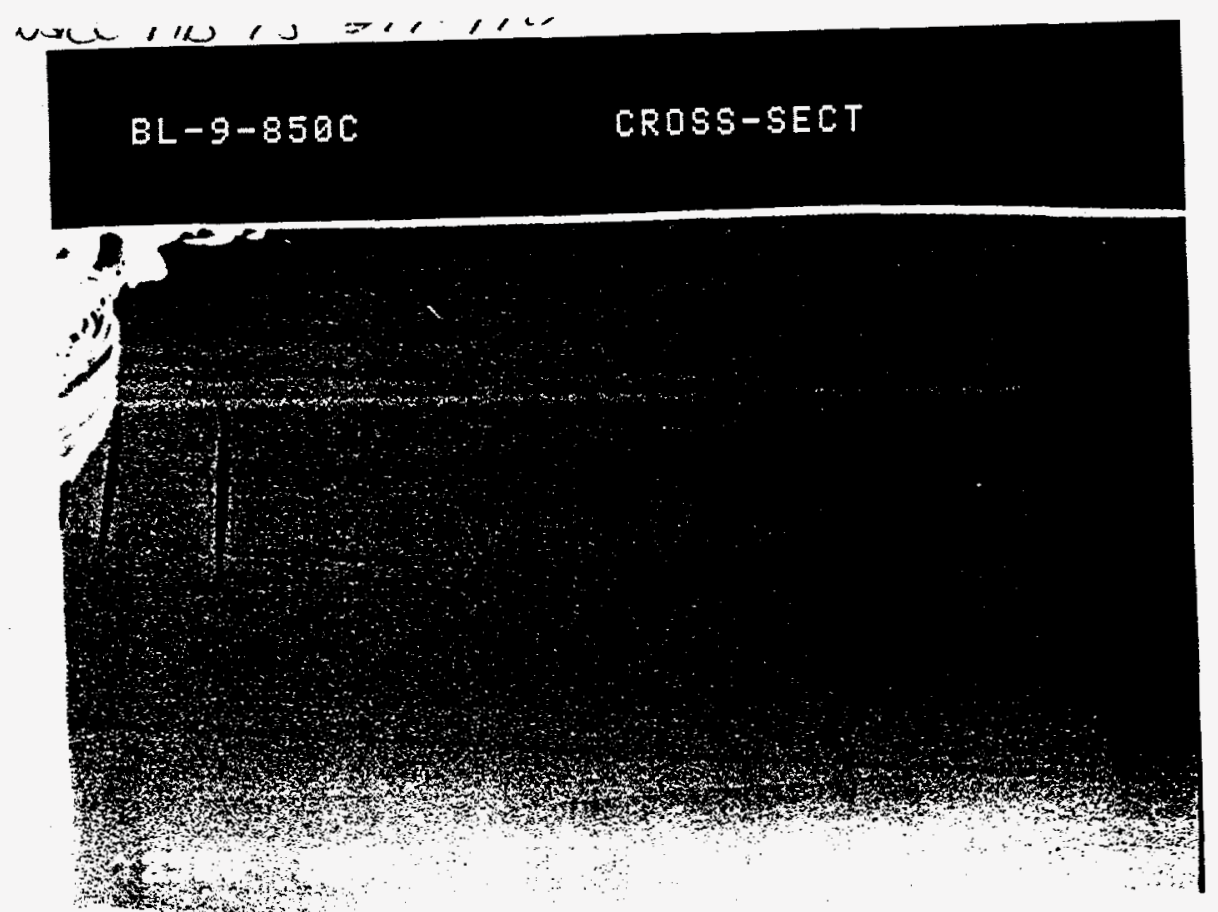

Figure 35. SEM Micrograph of BL-9 (HT 850) - Cross Sectional Image. 


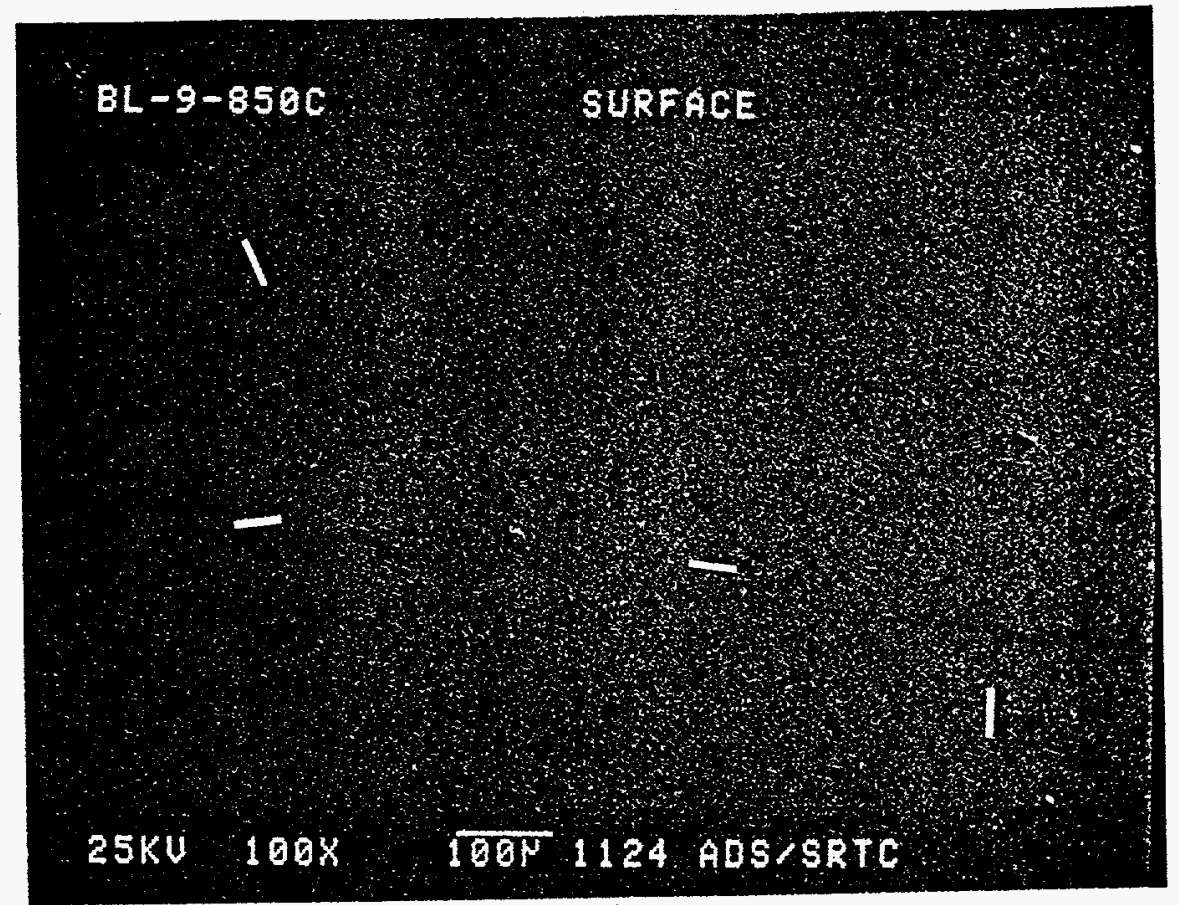

Figure 36. SEM Micrograph of "Surface Crystallization" (BL-9 (HT 850)) (100x).

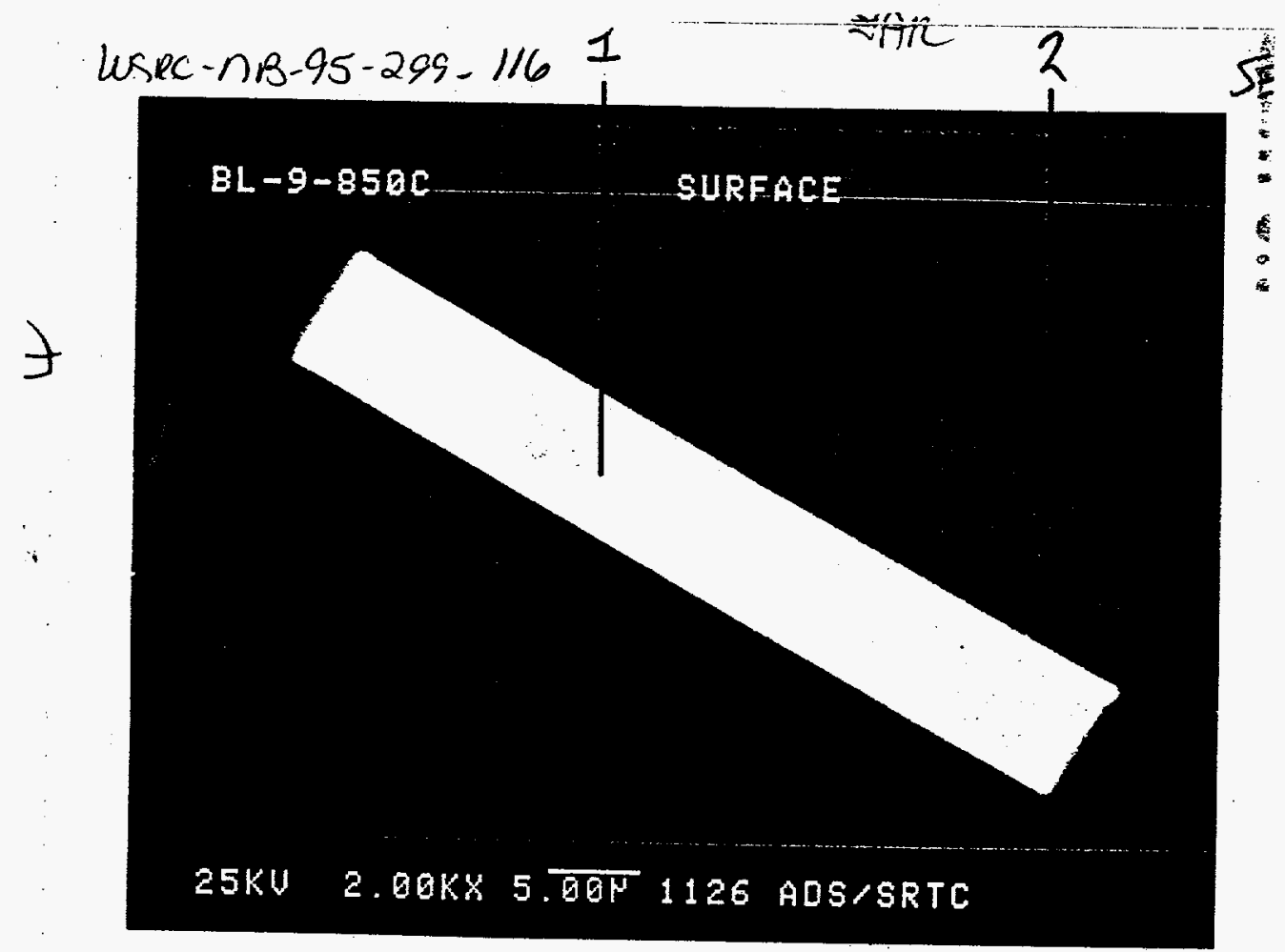

Figure 37. SEM Micrograph of "Surface Crystallization" (BL-9 (HT 850)) (2000x). 


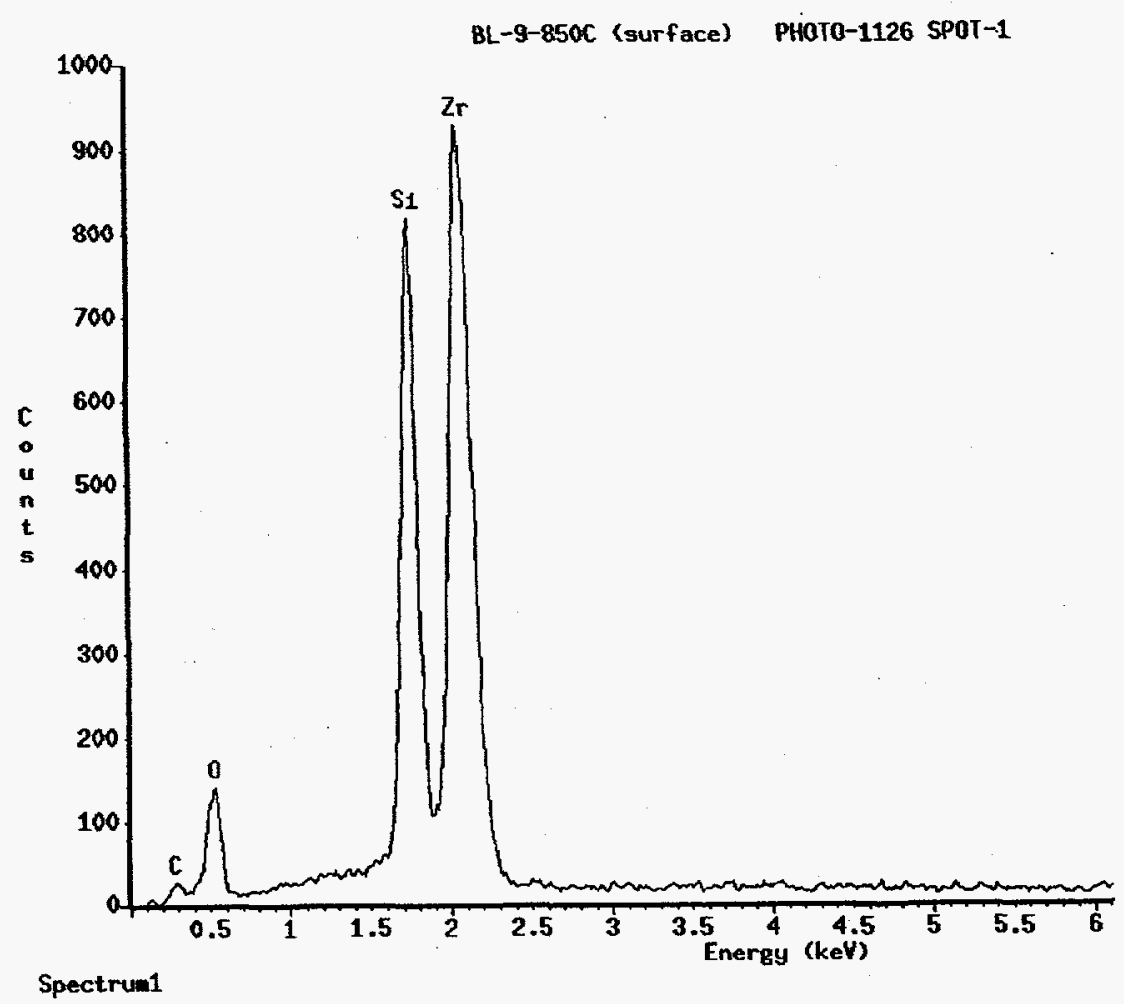

Figure 38. EDS Spectra of "Surface Crystallization" (BL-9 (HT 850)). 


\subsection{2 "Redissolution" Tests}

The drain tube is equipped with process air and a heater sleeve to initiate and stop pouring based on the dependence of viscosity with temperature. To initiate pouring the process air is shut off and the heater is placed around the drain tube. As the heater transmits energy to the drain tube, the glass softens and eventually begins to flow. To stop the glass flow, the heater is removed and air is blown on the drain tube tip. This increases the viscosity of the glass in the drain tube leading to a glass plug. Although a very workable system, this presents one technical issue regarding devitrification within the drain tube. A thermal gradient will exist along the length of the drain tube while the melter idles at $1150^{\circ} \mathrm{C}$ and air is blown on the drain tube tip. This gradient will tend to promote devitrification of any glass (as shown with $\mathrm{BL}-4, \mathrm{BL}-5, \mathrm{BL}-8$, and $\mathrm{BL}-9$ at $850^{\circ} \mathrm{C}$ ). As stated previously, the effect on devitrification on pouring depends on the type of crystallization, the extent of devitrification, and the ability to "redissolve" the primary crystalline phase. Dependent upon the type and extent of crystallization, complete blockage of the drain tube can result which would impede pouring.

\subsubsection{BL-4 and $B L-5$}

To address this issue, intentionally devitrified Bl-4 (HT 850) and BL-5 (HT850) samples were placed into

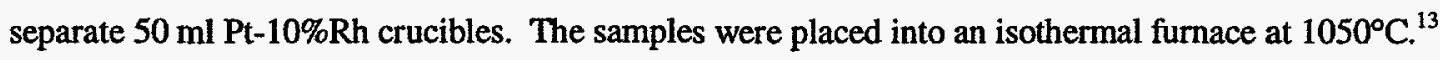
Samples were removed after 1.5 hours to see if the devitrification phase(s) $\left(\mathrm{Na}_{2} \mathrm{ZrSi}_{2} \mathrm{O}_{7}\right.$ and/or $\left.\mathrm{Li}_{2} \mathrm{SiO}_{3}\right)$ "redissolved".

Visual observations of BL-4 indicate complete redissolution of the devitrified phase occurred within 1.5 hours at $1050^{\circ} \mathrm{C}$. However, $\mathrm{XRD}$ of this sample did detect some undissolved $\mathrm{Na}_{2} \mathrm{ZrSi}_{2} \mathrm{O}_{7}$ (refer to Figure 40). Based on the $\mathrm{XRD}$ intensity levels, very little residual $\mathrm{Na}_{2} \mathrm{ZrSi}_{2} \mathrm{O}_{7}$ remains. Complete redissolution is likely if extended times were evaluated based on initial observation that $T_{L}$ is below $1050^{\circ} \mathrm{C}$.

Careful visual examination of the BL-5 sample $\left(1.5\right.$ hour at $\left.1050^{\circ} \mathrm{C}\right)$ indicated the presence of some undissolved material. XRD results (Figure 41) of the 1.5 hour sample indicate undissolved $\mathrm{Na}_{2} \mathrm{ZrSi}_{2} \mathrm{O}_{7}$ remaining in the sample. Based on the intensity levels the amount remaining is rather small.

Although the results of the $850^{\circ} \mathrm{C}$ heat treatments and redissolution tests are positive, it should be noted that only one time/temperature combination has been evaluated. There was no attempt to perform a full (or partial) time-temperature-transformation (TTT) diagram for this glass. The kinetics of crystallization for these glasses are not fully known.

$131050^{\circ} \mathrm{C}$ was chosen to represent the maximum temperature in which the drain tube could be reheated using the drain tube heater sleeve. 


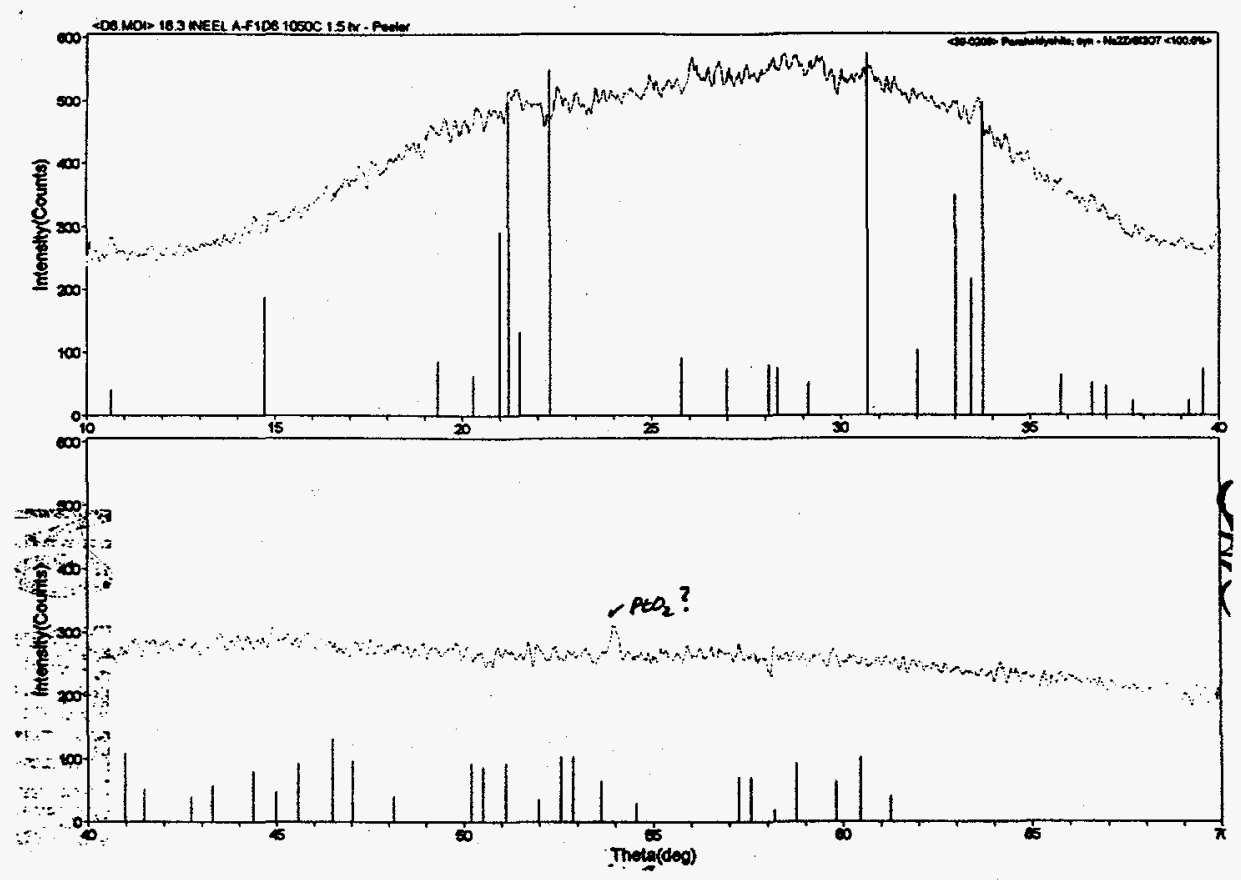

Figure 39. XRD Results of the "Redissolution Test" with BL-4 (HT 850).

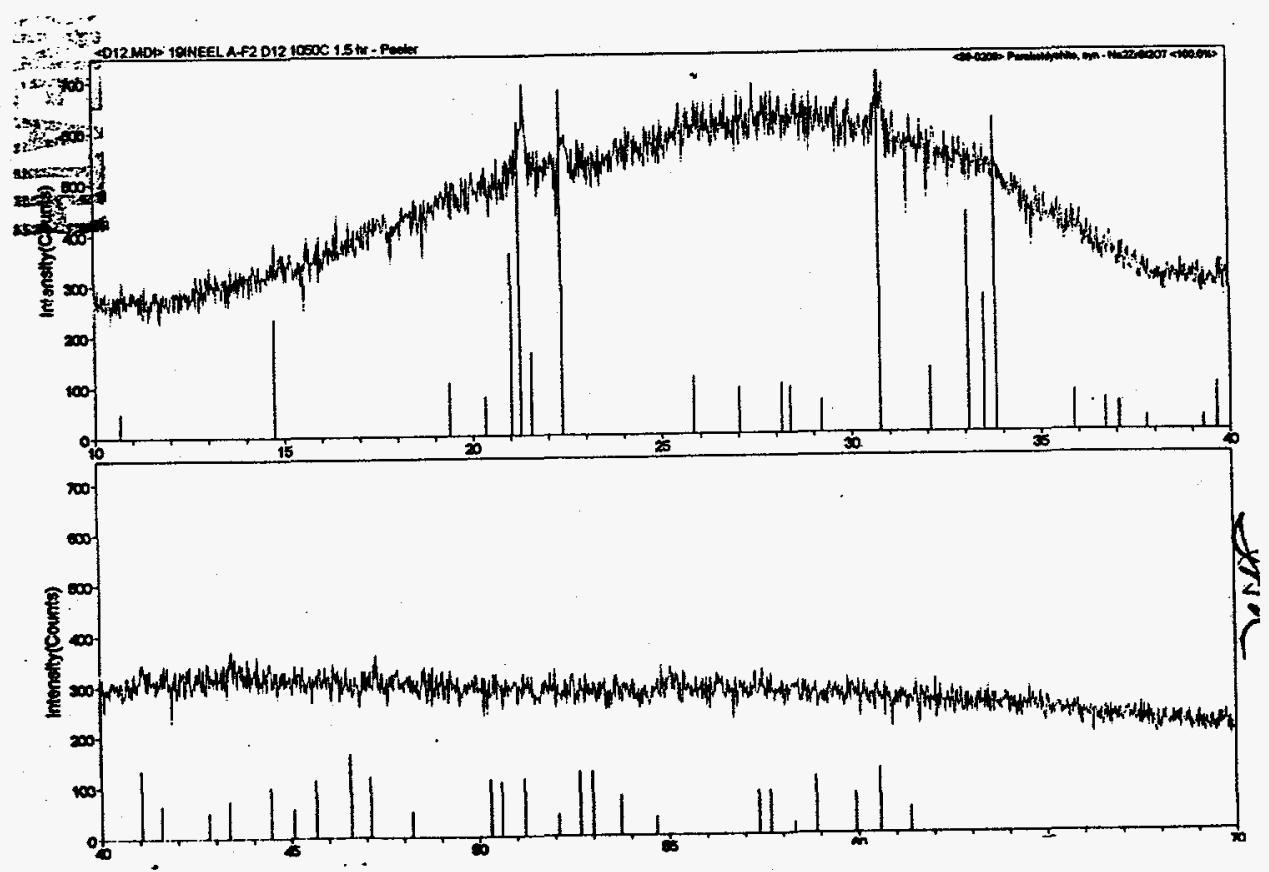

Figure 40. XRD Results of the "Redissolution Test" with BL-5 (HT 850). 


\subsubsection{2 $B L-8$ and $B L-9$}

To address the latter issue, intentionally devitrified BL-8 and BL-9 samples were placed into separate $50 \mathrm{ml}$ $\mathrm{Pt}-10 \%$ Rh crucible. The samples were placed into an isothermal furnace at $1050^{\circ} \mathrm{C}$. ${ }^{14}$ Samples were removed after 1,2 , and 4 hour(s) to see if the devitrification phase $\left(\mathrm{Na}_{2} \mathrm{ZrSi}_{2} \mathrm{O}_{7}\right)$ "redissolved".

Visual observations of both BL-8 and BL-9 indicate complete redissolution of the devitrified phase occurs within 4 hours at $1050^{\circ} \mathrm{C}$. Optical microscopy was used to confirm visual observations. Figures 42 and 43 show SEM micrographs of BL-8 and BL-9 after the 4 hour isothermal hold at $1050^{\circ} \mathrm{C}$ in an attempt to redissolve the devitrified phase. These micrographs confirm both visual observations and optical microscopy results that complete redissolution has occurred. It should be noted that after 1 hour at $1050^{\circ} \mathrm{C}$ less than 1\% crystals remained in each glass. XRD results of BL-8 and BL-9 (after the "redissolution" test at $1050^{\circ} \mathrm{C}$ ) are shown in Figures 44 and 45, respectively. The presence of the amorphous hump (or lack of well defined peaks) indicates no crystalline materials are present in the samples at the XRD detection limit.

${ }^{14} 1050^{\circ} \mathrm{C}$ was chosen to represent the maximum temperature in which the drain tube could be reheated using the drain tube heater. 


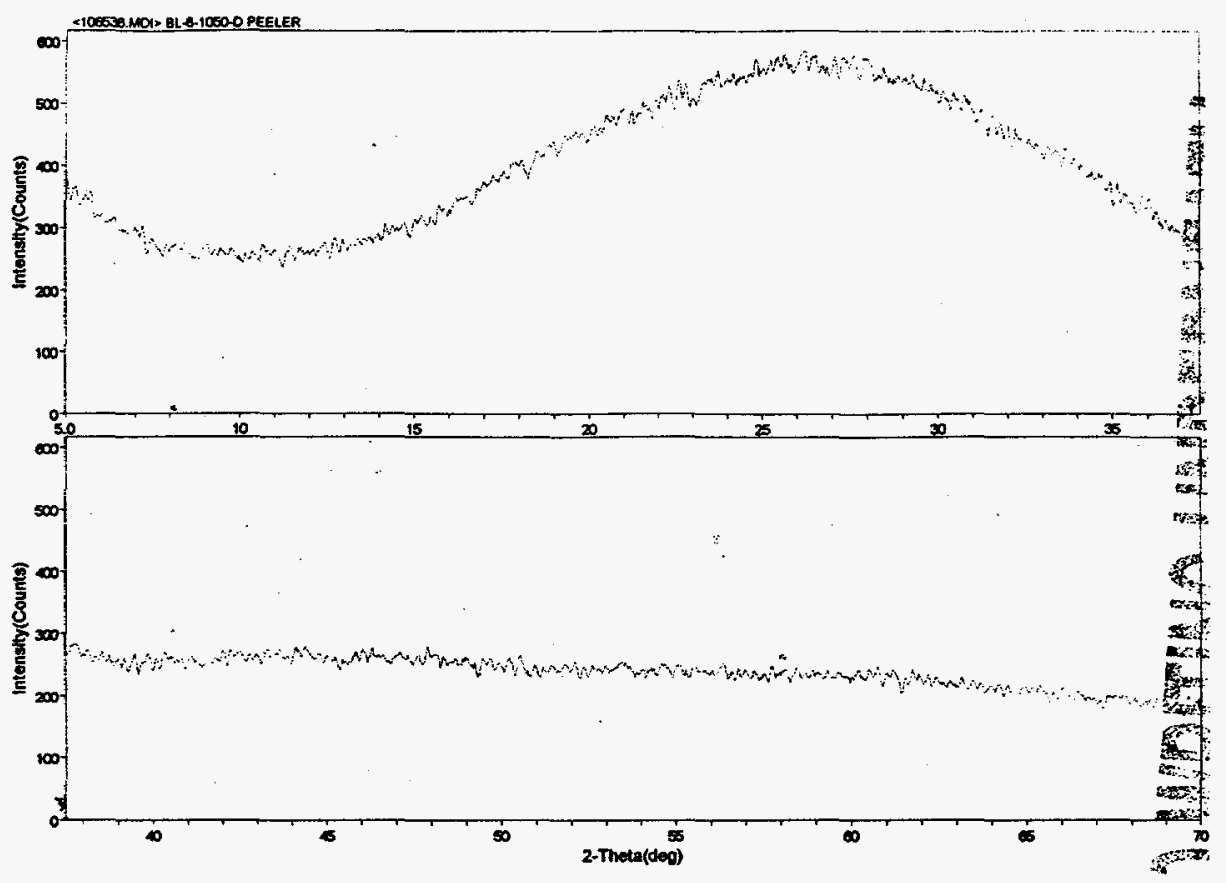

Figure 41. SEM Micrograph of BL-8 After "Redissolution" Tests at $1050^{\circ} \mathrm{C}$ for 4 Hours.

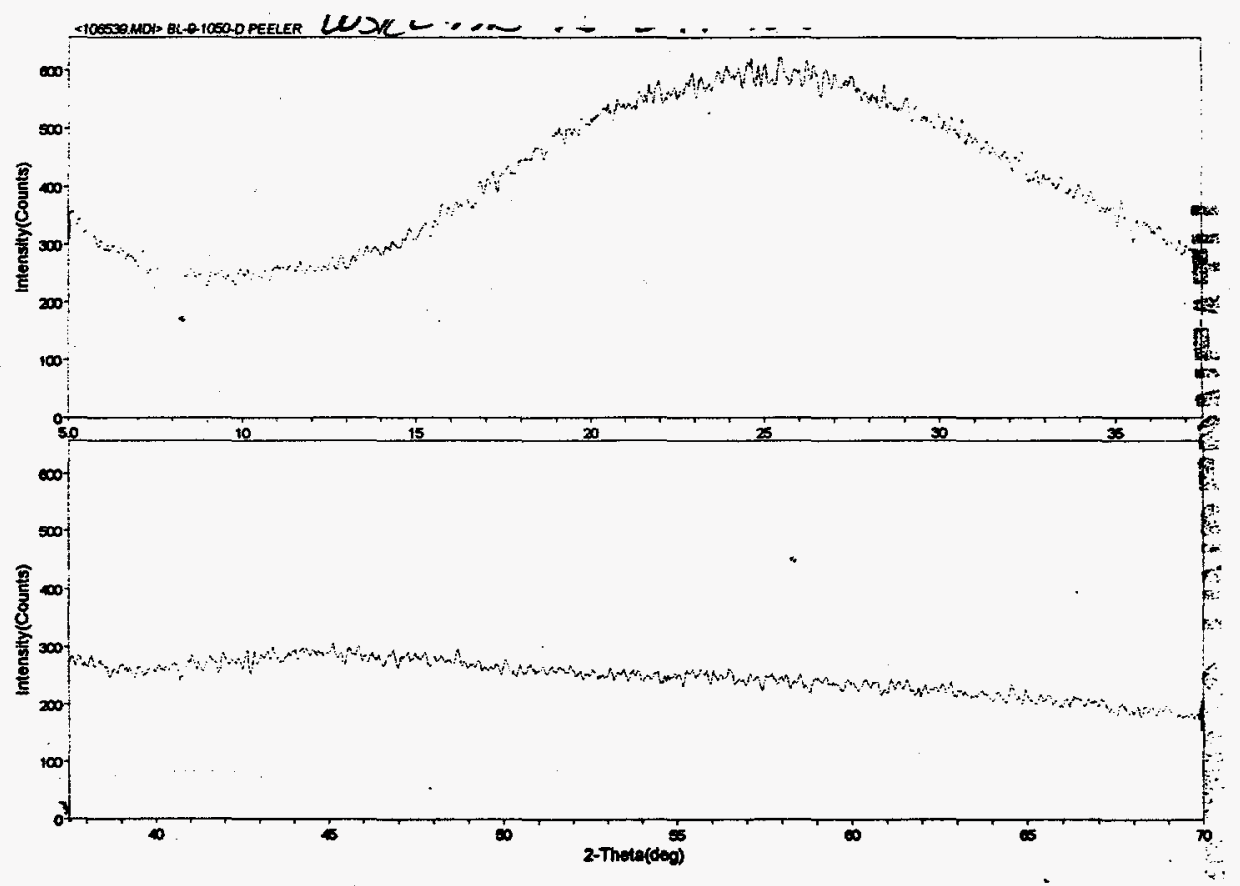

Figure 42. SEM Micrograph of BL-9 After "Redissolution" Tests at $1050^{\circ} \mathrm{C}$ for 4 Hours. 


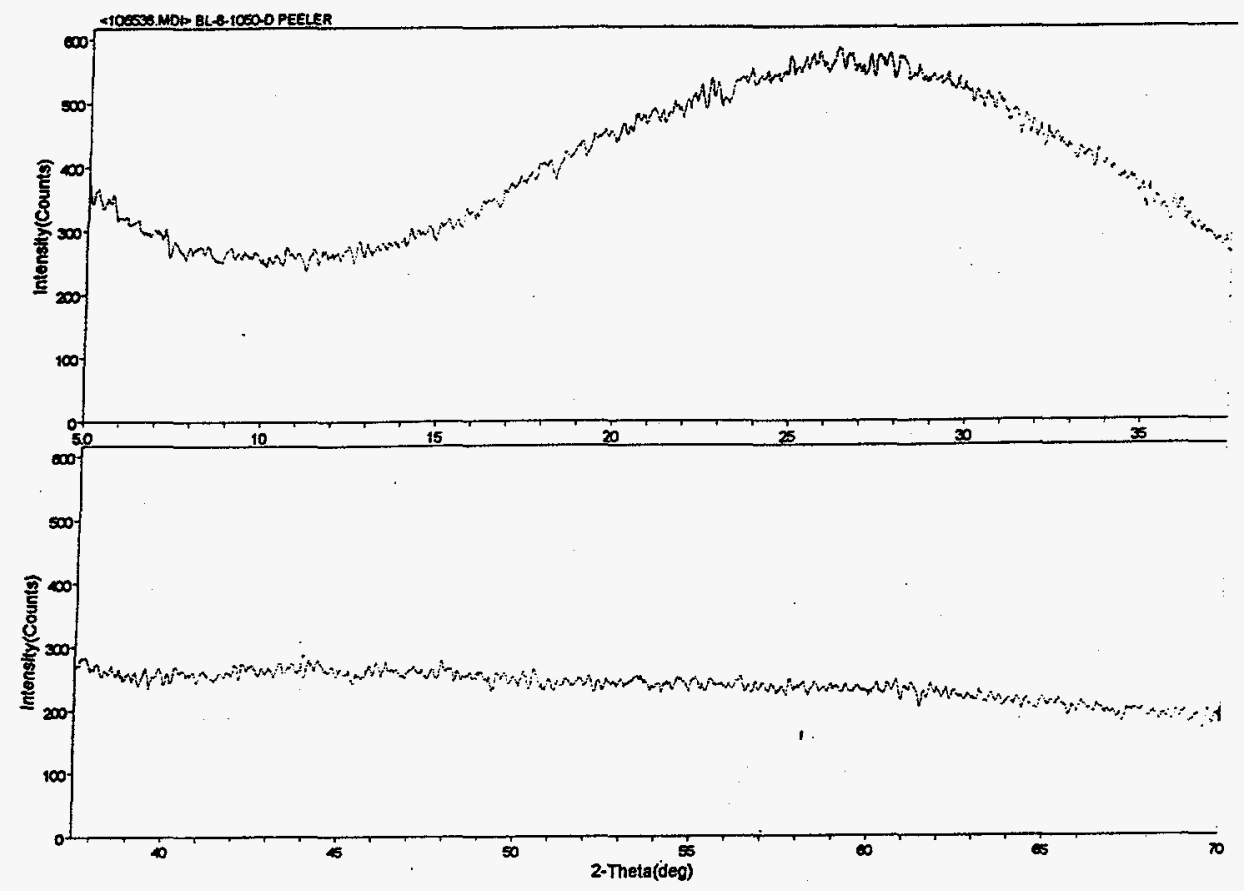

Figure 43. XRD Results of BL-8 After "Redissolution" Tests at $1050^{\circ} \mathrm{C}$ for 4 Hours.

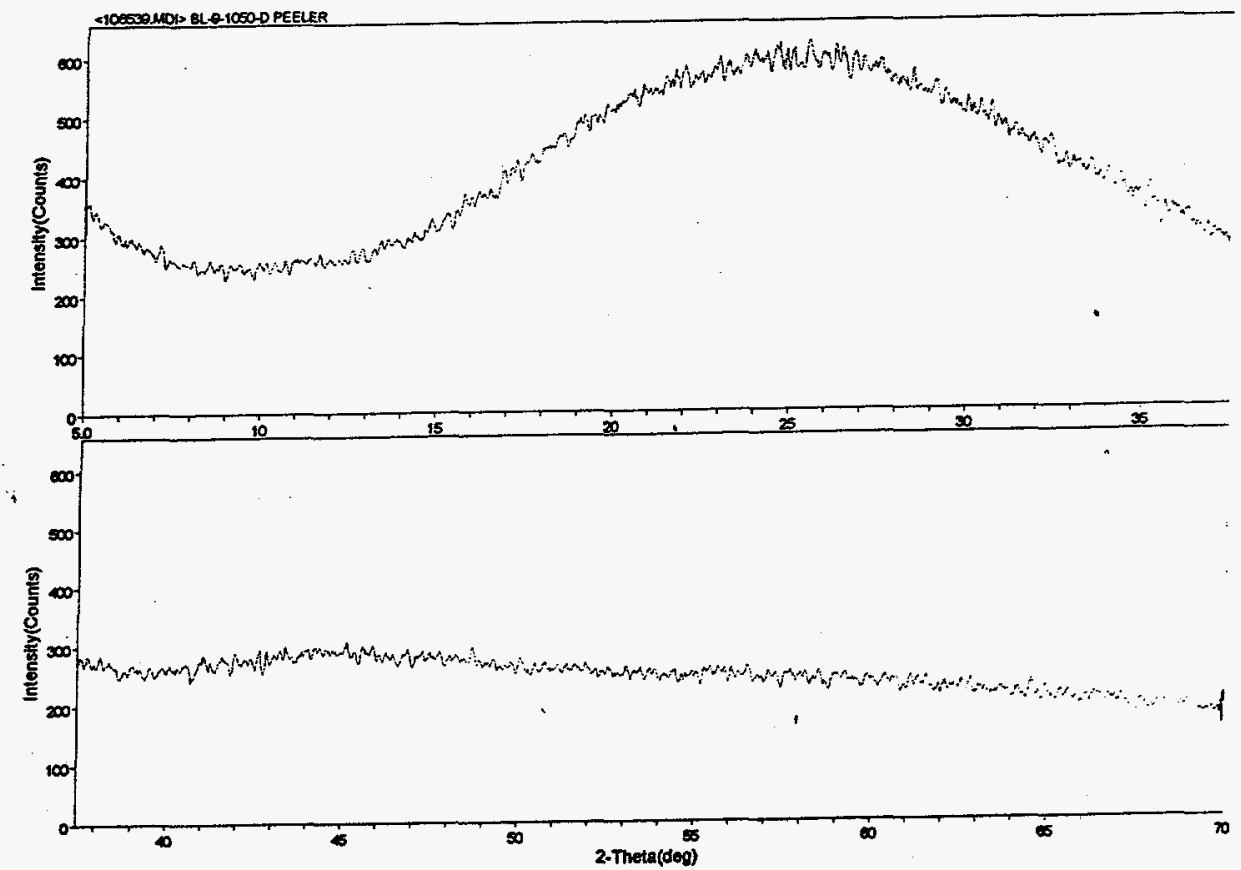

Figure 44. XRD Results of BL-9 After "Redissolution" Tests at $1050^{\circ} \mathrm{C}$ for 4 Hours. 
SRTC and PNNL recommend the following frit composition be used in the initial scaled melter run utilizing a simulated "All Blend" waste stream:

\begin{tabular}{|c|c|c|}
\hline Glass Identification: & BL-9 & \\
\hline & Oxide & $\underline{\mathrm{w} t} \%$ \\
\hline & $\overline{\mathrm{SiO}_{2}}$ & $\overline{62.63}$ \\
\hline & $\mathrm{B}_{2} \mathrm{O}_{3}$ & 18.52 \\
\hline & $\mathrm{Li}_{2} \mathrm{O}$ & 7.41 \\
\hline & $\mathrm{Na}_{2} \mathrm{O}$ & 11.44 \\
\hline Waste L & $19.0 \mathrm{wt} \%$ & \\
\hline Waste Stream: & "All Blend" & \\
\hline Nominal Processing Temperature: & $1150^{\circ} \mathrm{C}$ & \\
\hline
\end{tabular}

The target glass composition meets all targeted primary processing and product performance criteria. Liquidus temperature of $\mathrm{BL}-9$ is below $1050^{\circ} \mathrm{C}$ with $\mathrm{Na}_{2} \mathrm{ZrSi}_{2} \mathrm{O}_{7}$ identified as the primary crystalline phase. The measured viscosity at $1150^{\circ} \mathrm{C}$ is 59 Poise (5.9 Pa॰s). Durability results (as defined by the PCT) indicate that the normalized releases of $\mathrm{B}, \mathrm{Li}$, and $\mathrm{Na}$ are an order of magnitude below those of the $\mathrm{EA}$ glass.

The results of this initial work show that immobilization via vitrification is a viable option for the "All Blend" INEEL. HAW stream. Waste loadings of at least 19 wt\% can be achieved for the "All Blend" stream while maintaining targeted processing and product performance criteria. These waste loadings translate into $\mathrm{ZrO}_{2}$ contents in excess of $15 \mathrm{wt} \%$ in the final glass waste form. The developed frits are based on the alkali borosilicate system. Although the results indicate that vitrification is a viable options for INEEL, the glasses fabricated are by no means optimized.

SRTC and PNNL recommend that INEEL fabricate and test (on a laboratory-scale) BL-9 to confirm that the glass meets all specifications prior to melter processing. This study has not addressed scale-up issues (i.e., crucible scale to melter scale). One concern that was only partially addressed in an effort to reduce technical risk was the devitrification potential within the drain tube during melter idling. Although the limited results suggests that devitrification may occur within the drain tube, based on the type and extent of devitrification for a single data point, the crystals will readily redissolve at $1050^{\circ} \mathrm{C}$. 


\subsection{References}

1. G.F. Piepel, J.D. Vienna, and P. Hrma, "Phase 1 Experimental Design for the INEEL HLW Glass Composition Variation Study", PNNL-SA-29594, Rev. 1, Pacific Northwest National Laboratory, January 1998.

2. S.K. Sundaram, John Vienna, J. V. Crum, Irene Reamer, and David Peeler, INEEL HLW Corrosion And Glass Composition Variation Studies - Initial Results, PNNL-SA-29594, Rev. 1, Pacific Northwest National Laboratory, Richland Washington, (1998).

3. Waste Acceptance Product Specifications for Vitrified High-Level Waste Forms, Office of Environmental Restoration and Waste Management, U.S. Department of Energy, Washington, D.C., February 1993.

4. ASTM, "Standard Test Method for Determining Chemical Durability of Nuclear Waste Glasses: The Product Consistency Test (PCT)", ASTM-C-1285-94, 1994.

5. C.M. Jantzen, N.E. Bibler, D.C. Beam, C.L. Crawford, and M.A. Pickett, "Characterization of the Defense Waste Processing Facility (DWPF) Environmental Assessment (EA) Glass Standard Reference Material (U)," WSRC-TR-92-346, Revision 1, Westinghouse Savannah River Company, Aiken, SC.

6. "Laboratory-Scale Glass Preparation Procedure", GTOP-3-106, Westinghouse Savannah River Company, Savannah River Technology Center, Aiken, SC.

7. "Glass Melting Procedure", GTOP-3-004, Westinghouse Savannah River Company, Savannah River Technology Center, Aiken, SC.

8. "Procedure for Glass Batching and Melting", PSL-417-GBM, Pacific Northwest National Laboratory, Richland, WA.

9. "Standard Viscosity Measurement Procedure", GDL-VIS, Pacific Northwest National Laboratory, Richland, WA.

10. High-Level Waste Borosilicate Glass A Compendium of Corrosion Characteristics, DOE-EM-0177, Volumes 1-3, Edited by J.C. Cunnane, March 1994.

11. "Glass Optimization for Vitrification of Hanford Low-Level Tank Waste, X. Feng, P.R. Hrma, M.J. Schweiger, H. Li, G.F. Piepel, D.K. Peeler, S.E. Palmer, D.E. Smith, D. Kim, B.P. McGrail, Y. Peng, A.J. Bakel, and W.L. Ebert, PNNL-10918, March 1996.

12. "Evaluation of Phase II Glass Formulations for Vitrification of Hanford Site Low-Level Waste", X. Feng, M.J. Schweiger, P.R. Hrma, D.K. Peeler, S.E. Palmer, B.P. McGrail, D.E. Smith, D. Kim, Y. Peng, and H. Li, PNNL-11013, March 1996.

13. "Glass Composition Development for High Sodium Content Nuclear Waste", J.C. Marra, M.J. Plodinec, and T.D. Taylor, Ceramic Transactions, Volume 61, p. 317 - 324 (1995).

14. JD Vienna, PR Hrma, MJ Schweiger, MH Langowski, PE Redgate, DS Kim, GF Peipel, DE Smith, CY Chang, DE Rinehart, SE Palmer, and $\mathrm{H} \mathrm{Li}$, Effect of Composition and Temperature on the Properties of High-Level Waste Glass Melting Above $1200^{\circ} \mathrm{C}$, Draft, PNNL-10987, Pacific Northwest National Laboratory, Richland Washington, (1996). 